\title{
Treaty-Based Rights and Remedies of Individuals
}

Carlos Manuel Vázquez

Georgetown University Law Center, vazquez@law.georgetown.edu

Georgetown Public Law and Legal Theory Research Paper No. 12-102

This paper can be downloaded free of charge from:

https://scholarship.law.georgetown.edu/facpub/1015

http://ssrn.com/abstract=2114480

92 Colum. L. Rev. 1082-1163 (1992)

This open-access article is brought to you by the Georgetown Law Library. Posted with permission of the author. Follow this and additional works at: https://scholarship.law.georgetown.edu/facpub

Part of the Constitutional Law Commons, Courts Commons, and the International Law Commons 


\section{TREATY-BASED RIGHTS AND REMEDIES OF INDIVIDUALS}

\section{Carlos Manuel Vázquez*}

Treaties are frequently described as contracts between nations. ${ }^{1}$ As instruments of international law, they establish obligations with which international law requires the parties to comply. In the United States, treaties also have the status of law in the domestic legal system. The Supremacy Clause declares treaties to be the "supreme Law of the Land" and instructs the courts to give them effect. ${ }^{2}$ The status of treaties as law in two distinct legal orders has given rise to unusual conceptual problems. In recent years, it has produced confusion among the courts regarding the enforceability of treaties in the courts by individuals. As Chief Justice Marshall long ago observed, "[ $t]$ he province of the court is, solely, to decide on the rights of individuals . ..."3 Accordingly, it is frequently said that treaties are enforceable by individuals in our courts only when they confer rights on individuals. ${ }^{4}$ Yet it is widely held that treaties, as international instruments, establish legal obligations and correlative legal rights only of the nations that are parties to them, not of individuals. ${ }^{5}$

The conjunction of these two propositions has led some courts to

* Associate Professor of Law, Georgetown University Law Center. B.A. Yale; J.D. Columbia. I am grateful to Anita Allen, David Cole, Steven Goldberg, Michael Gottesman, Vicki Jackson, Jane Stromseth, Mark Tushnet, and the other participants in Georgetown's Faculty Research Workshop for their comments on an earlier draft of this Article. I also gratefully acknowledge the research assistance of Joseph C. Bryce, Stephen J. Campo, José Carlos Fraga, and Timothy Hruby. I have previously addressed some of the issues discussed in this Article in briefs amicus curiae filed in Haitian Refugee Ctr. v. Gracey, 809 F.2d 794 (D.C. Cir. 1987) and Haitian Refugee Ctr. v. Baker, 949 F.2d 1109 (11th Cir. 1991).

1. See Geofroy v. Riggs, 133 U.S. 258, 271 (1890); Foster v. Neilson, 27 U.S. (2 . Pet.) 253, 314 (1829).

2. U.S. Const. art. VI, cl. 2.

3. Marbury v. Madison, 5 U.S. (1 Cranch) 137,170 (1803).

4. See, e.g., Haitian Refugee Ctr. v. Baker, 949 F.2d 1109, 1110 (11th Cir. 1991) (treaty must "directly accord[] enforceable rights to persons"), cert. denied, $112 \mathrm{~S}$. Ct. 1295 (1992); Committee of U.S. Citizens Living in Nicar. v. Reagan, 859 F.2d 929, 937 (D.C. Cir. 1988) (treaty must "confer rights on private individuals"); United States v. Bent-Santana, 774 F.2d 1545, 1550 (11th Cir. 1985) (treaty must confer "privately enforceable rights"); Frolova v. U.S.S.R., 761 F.2d 370, 374 (7th Cir. 1985) (treaty must confer "rights enforceable by private litigants in American courts"); cf. Head Money Cases, 112 U.S. 580, 598-99 (1884) (treaty enforceable by individuals when "its provisions prescribe a rule by which the rights of the private citizens or subject may be determined").

5. See, e.g., United States v. Zabeneh, 837 F.2d 1249, 1261 (5th Cir. 1988); United States v. Cordero, 668 F.2d 32, 37-38 (1st Cir. 1981); United States ex rel. Lujan v. Gengler, 510 F.2d 62, 67 (2d Cir.), cert. denied, 421 U.S. 1001 (1975); United States v. Yunis, 681 F. Supp. 909,916 (D.D.C. 1988); cases cited infra note 6. 
dismiss individuals' treaty-based claims or defenses out of hand. ${ }^{6}$ Other courts have accepted the general validity of the premises but have permitted individuals in particular circumstances to vindicate the rights of the states-parties. The recent Ninth Circuit decisions in United States v. Verdugo-Urquidez ${ }^{7}$ and United States $v$. Alvarez-Machain ${ }^{8}$ illustrate the latter approach. The defendants, Mexican nationals accused of murdering DEA agent Enrique Camarena, claimed that they had been abducted from Mexico and brought to the United States by persons acting at the behest of the United States government. ${ }^{9}$ They argued that their abduction violated the United States' obligations under its extradition treaty with Mexico and that, accordingly, they must be repatriated. ${ }^{10}$ The Ninth Circuit in Verdugo agreed that the extradition treaty prohibited the United States from abducting persons from Mexican territory. ${ }^{11}$ It then turned to what it considered the more difficult issue: whether the defendants had standing to raise the treaty prohibition. The court held that, because Mexico had protested the abduction, the defendants had derivative standing to enforce Mexico's rights under the treaty. ${ }^{12}$ Mexico's protest distinguished these cases from prior decisions that had denied defendants standing to raise similar treaty provisions. ${ }^{13}$

The holdings in Verdugo and Alvarez, and in the cases that the Ninth Circuit distinguished, were based, either explicitly or implicitly, on the two premises mentioned above: that individuals do not have rights under treaties as a matter of international law and that individuals may enforce treaties domestically on their own behalf only when they have rights under the treaties as a matter of international law. If both premises were true, and if the Ninth Circuit's derivative standing holding were rejected, ${ }^{14}$ treaties would never be enforceable by individuals in our courts. But, if so, and if the province of the courts is solely to de-

6. See, e.g., Matta-Ballesteros v. Henman, 896 F.2d 255, 259 (7th Cir.), cert. denied, 111 S. Ct. 209 (1990); Zabeneh, 837 F.2d at 1261; Cordero, 668 F.2d at 38; Dreyfus v. Von Finck, 534 F.2d 24, 29 (2d Cir.), cert. denied, 429 U.S. 835 (1976); United States v. Martinez, 755 F. Supp. 1031, 1034-35 (N.D. Ga. 1991); United States v. Noriega, 746 F. Supp. 1506, 1533-35 (S.D. Fla. 1990); Yunis, 681 F. Supp. at 916.

7. 939 F.2d 1341 (9th Cir. 1991), petition for cert. filed, 60 U.S.L.W. 3344 (U.S. Oct. 21, 1991) (No. 91-670).

8. 946 F.2d 1466 (9th Cir.), cert. granted, 112 S. Ct. 857 (1991).

9. See Alvarez, 946 F.2d at 1467; Verdugo, 939 F.2d at 1343.

10. See Alvarez, 946 F.2d at 1467; Verdugo, 939 F.2d at 1359.

11. See Verdugo, 939 F.2d at 1352.

12. The Court said that "an individual who is not a party to an agreement between the United States and a foreign nation [may] assert the rights of that nation in our courts." 939 F.2d at 1356.

13. See id. at 1346-47. The court in Alvarez followed the Verdugo decision.

14. The U.S. Justice Department argues that the Ninth Circuit's standing holding should be reversed. Petition for the United States for Certiorari at 19-21, Verdugo (No. 91-670); Brief for United States at 35-37, Alvarez (No. 91-712) [hereinafter Brief for the United States in Alvarez]; Reply Brief for United States at 15-17, Alvarez (No. 91-712). 
cide the rights of individuals, how would the Supremacy Clause's mandate that courts give effect to treaties as law of the land be fulfilled? The answer offered here is that, by declaring treaties to be laws, the Framers meant to make treaties enforceable by individuals in our courts. That the Framers considered it the province of the courts to say what the law is and to decide the rights of individuals shows that, by declaring treaties to be laws and instructing courts to give them effect, the Framers intended to alter (or make irrelevant) for domestic purposes those qualities of treaties as instruments of international law that have recently been advanced to deny individuals standing to enforce them.

Part I of this Article examines what is meant by the statement that individuals do not have rights under treaties as a matter of international law. I conclude that this statement means only that individuals lack the power to set in motion the machinery of international law for enforcing treaty obligations. I call this the classic conception of the position of the individual in interuational law, which reflects the strict sanctionist sense of the term "right." That treaties have long been enforced in our domestic courts, however, must mean either that the classic model does not accurately describe international law or that the ability of individuals to enforce treaties domestically does not turn on whether the treaty confers rights on individuals, in the strict sanctionist sense, as a matter of interuational law. I conclude that the enforceability of treaties domestically is not explained by any claimed inaccuracy of the classic model. Treaties have been enforced by individuals in our courts throughout our history, even during the heyday of the classic model. If it is a condition of a treaty's enforceability by individuals in our courts that the treaty confer rights on individuals, the term right in this context cannot be understood in its strict sanctionist sense.

This, moreover, is exactly what the Framers intended. In Part II of this Article, I show that the Framers understood that treaties, as international instruments, were operative on states as bodies politic, not on individuals, and were dependent for their enforcement on either military force or the good faith of the parties. It was precisely these qualities of treaties that distinguished them, in the Framers' eyes, from laws. In the view of the Framers, laws were, by their nature, operative on individuals and enforceable in the ordinary courts.

The inability of the general government under the Articles of Confederation to secure compliance with the nation's treaties, the acts of Congress, or the Articles themselves was among the principal animating causes of the Framers' decision to draft a new Constitution. The Framers attributed the inefficacy of the Articles to the qualities the Articles and acts of Congress shared with treaties: all three were operative on states as political bodies, rather than on individuals, and were dependent for their enforcement on the good faith of the parties or on 
military force. They were not laws; because they lacked a legal sanction, they were only morally binding.

The Framers corrected this problem with respect to treaties in the same way they corrected it with respect to the acts of Congress and the foundational document itself: they gave all three the status of "law." This, in the Framers' view, made all three operative directly on individuals and enforceable in the ordinary courts. Today, it is well recognized that the institution of judicial review of legislative acts springs from the Supremacy Clause's designation of the Constitution as law. It is on the basis of the Constitution's status as law that we reject the conclusion that the Constitution is but a political document allocating powers among branches of government and not establishing judicially enforceable correlative rights of individuals. It is time to recognize that the Supremacy Clause had the very same effect with respect to treaties.

That the Supremacy Clause makes treaties enforceable in the courts by individuals does not, of course, mean that any individual may enforce any treaty at any time. In Part Ill of this Article, I propose a framework for determining which treaties may be enforced by individuals, which individuals may enforce them, and what remedies they may obtain. Consistent with the Supremacy Clause's equivalent treatment of the Constitution, treaties, and the acts of Congress, I propose that we address these problems with respect to treaties much as we address them with respect to the other categories of laws. First, as with constitutional and statutory provisions, treaties should be enforceable in the courts only if they impose enforceable legal obligations. They should not be enforced by the courts if they are hortatory, if they do not establish the obligation the litigant seeks to enforce, or if they raise political rather than legal questions. Second, the obligations established by treaties should be enforceable only by individuals who have correlative primary rights. Ordinarily, a primary right is the obverse of primary duty and the holder of the primary right is easily identifiable. In ambiguous cases, I propose that standing principles be employed to determine when an individual has a primary right under a treaty, as they are with respect to constitutional and statutory provisions that impose obligations on the state. If the party relying on the treaty is seeking affirmative relief, rather than merely relying on the treaty as a defense, the party must establish in addition that he has a "right of action." There are a number of possible sources, other than the treaty itself, for the right of action of a plaintiff relying on a treaty. In the last section, I examine some of these bases and discuss how to determine, when there is no other basis for the plaintiff's action, whether a treaty itself confers a private right of action. Finally, I discuss how courts should decide what remedies to afford individuals for treaty violations. For this last purpose, I propose that, consistent with the Framers' intent to minimize violations of international law by the United States, the Supremacy Clause be read to entitle individuals in our courts to such 
remedies for treaty violations as would prevent or cure a violation by the United States of its international law obligations to the state of the individual's nationality.

Many of the issues discussed in Part 111 of this Article are addressed by the courts today, incidentally and un-self-consciously, in the course of determining whether a treaty is self-executing. The courts, however, appear to regard the question whether or not the treaty is self-executing as distinct from, although perhaps related to, each of the foregoing issues. In Part III, I unpack the doctrine of self-executing treaties and show that it in fact masks a variety of distinct reasons why a treaty may be unenforceable in the courts by individuals without further legislation. Failure to recognize the variety of the issues addressed under the self-execution rubric has produced what has been called the "most confounding [doctrine] in treaty law." 15 I urge that these issues be addressed by the courts separately and self-consciously, not through the ambiguous and little-understood doctrine of self-executing treaties.

\section{TREaty Rights of Individuals Under InTERnational and DOMESTIC LAW}

Some lower courts and the U.S. Justice Department have recently advanced the position that a treaty may be invoked by individuals in our domestic courts only when the treaty confers rights on individuals as a matter of international law. ${ }^{16}$ But in the international legal order, as classically conceived, individuals do not have rights and duties: only sovereign states are thought to be subjects of international law and accordingly only states are thought to have rights and duties thereunder. If it were true that individuals can enforce treaties in our domestic courts only when they have rights under them as a matter of international law, and if it were true that individuals do not have rights under treaties as a matter of international law, then individuals would never be able to enforce treaties in domestic courts.

But treaties have long been successfully enforced by individuals in our courts. For this reason, one of these two premises would appear to be false: either it is not true that treaties may be invoked by individuals in our courts only if they confer rights on individuals as a matter of international law, or the classic model does not accurately describe all rules of international law.

Although the classic model may not accurately describe all rules of international law either today or at the time the Constitution was adopted, the enforceability of treaties by individuals in our domestic courts cannot be explained by the claimed inaccuracies of the classic model. Individuals have successfully enforced treaties in our domestic

15. United States v. Postal, 589 F.2d 862, 876 (5th Cir.), cert. denied, 444 U.S. 832 (1979).

16. See supra notes 4-14. 
courts even though they would not have been considered to have had rights under the treaty as a matter of international law. Those who maintain that a treaty may be invoked by individuals in domestic courts only if it confers "rights" on individuals use the term "rights" to mean something quite different from what it means to those who maintain that individuals do not have "rights" under international law.

In this Part, I examine what exactly is meant by the statement that individuals do not have "rights" under international law. I conclude that those who make that statement are using the term "right" in the strict sanctionist sense that ties the existence of a right to the legal power of the right-holder to invoke the machinery of the legal system to enforce compliance or remedy violations. So understood, the statement that individuals do not have rights under a treaty as a matter of international law was true in 1789 and remains largely true today. But that disability has never defeated an individual's ability to enforce a treaty in our domestic courts.

\section{A. Individuals As Holders of Rights Under International Law}

The statement that individuals do not have rights under international law is at bottom a statement that individuals do not have secondary rights under international law-they lack the power to set in motion the machinery of international law for sanctioning violations of the obligations international law imposes. The classic model does not deny, however, that individuals may be holders of primary rights under international law: they may be the direct and intended beneficiaries of obligations imposed on states by international law. An Austinian positivist would deny that a primary right is a legal right if a secondary right is not annexed to it. Others would disagree. Whatever the merits of the ontological debate, the term "right" is susceptible to both significations. Recognizing the two senses of the term "right" permits us to reconcile the two premises with which this Article began: while the statement that individuals do not have rights under international law employs the term in its strict sanctionist sense, the statement that individuals may enforce treaties domestically only if the treaty confers rights on them as a matter of international law accurately describes the legal landscape only if the term is understood in the sense of a primary right.

As described by Vattel, the law of nations is the law that governs the society of sovereign states, just as municipal laws are the laws that govern societies of persons. Nations or states, according to Vattel, "are bodies politic, societies of men united together for the purpose of promoting their mutual safety and advantage by the joint efforts of their combined strength." 17 States, in turn, are "moral persons who live to- 
gether in a natural society, subject to the law of nations."18 Thus, what persons are to municipal law, states are to international law. Just as persons are the subjects of the municipal law of a state, and thus only persons have rights and duties under municipal law, states are the subjects of the law of nations and only states enjoy rights and duties thereunder. ${ }^{19}$

The classic model does not deny that international law imposes obligations on states to behave in given ways towards individuals. But the duties so imposed are not thought to give rise to correlative rights in the individuals affected; the duties are considered to be owed to the states of which the individuals are citizens or subjects, and the correlative rights are rights of such states, not of the individuals. Again, there is a parallel in municipal law. Municipal law recognizes the existence of objects, such as land, trees, and chairs, and it may require persons to treat them in certain ways, but such duties are duties towards other persons-either individually or collectively-and the correlative rights are rights of those other persons; they have not been thought to be the rights of the objects. ${ }^{20}$ ln other words, only persons are the subjects of

1863). This work first appeared in 1758 , see id. at $\dddot{i i}$, and was well known to, and often cited with approval by, the Framers of our Constitution. Thomas Jefferson is reported to have said that "none is more [enlightened and disinterested a judge of the law of nature and the usage of nations] than Vattel." Charles G. Fenwick, The Authority of Vattel, 7 Am. Pol. Sci. Rev. 395, 410 (1913). Alexander Hamilton described Vattel as "perhaps the most accurate and approved of the writers on the Law of Nations." Daniel George Lang, Foreign Policy in the Early Republic 11 (1985).

18. Vattel, supra note 17 , at 2 .

19. Pufendorf, Grotius, and Burlamaqui, among others, all shared this conception of international law as the law that governed the society of states, each considered as a moral or juristic person. See Edwin D. Dickinson, Changing Concepts and the Doctrine of Incorporation, 26 Am. J. Int'l L. 239, 240-47 (1932). The content of much of the law of nations according to Vattel and Grotius, and of all of it according to Pufendorf and Burlamaqui, was derived from the law of nature. See id. Unlike persons in a civil society, states had not surrendered any portion of their liberty or independence to any public authority. Thus, they composed a society of moral persons in a state of nature, like persons who, "before the establishment of civil societies, lived together in a state of nature." Vattel, supra note 17, at lv. The notion that the law of nations is derived from principles of natural law was thus not considered by these writers to be inconsistent with the notion that only states are the subjects of international law.

By the nineteenth century, the content of international law was understood to be derived primarily, if not entirely, from other sources, such as custom or convention. During this period, the conception of international law as the law governing the society of nations, each considered to be a moral person, persisted and indeed gained strength, and it continues to be the predominant view.

20. See Michael Akehurst, A Modern Introduction to International Law 70 (6th ed. 1987) ("In the nineteenth century ... international law regarded individuals in much the same way as municipal law regards animals."). Just as international law has evolved to the point where entities other than sovereign states may have rights thereunder, it has been argued that municipal law too should recognize rights of things other than persons. See Christopher D. Stone, Should Trees Have Standing?: Toward Legal Rights for Natural Objects (1972). Nevertheless, it has been generally accepted throughout our history that only persons (and associations of persons, such as 
rights and duties under municipal law; land, trees, and chairs may, however, be the objects of such rights and duties. Similarly, individuals have been described as the "objects" rather than the "subjects" of international law. ${ }^{21}$

But if international law imposes obligations on states to behave in certain ways towards individuals, in what respect do individuals lack "rights" under international law? Under the classic model, if state A is obligated to behave in a given way towards the nationals of state $B$, the obligation is thought to be owed to the aggregate of the individuals making up state $B$. If state $A$ violates an obligation, it becomes responsible not to the national, but to state $B$ as a society. If it does not repair the injury, only state $B$ is permitted by international law to set in motion the machinery of international law for sanctioning violations of the relevant international law norm. State $B$, however, has the discretion not to pursue an international claim; it may subordinate the interests of the individual to those of the larger society. ${ }^{22}$ For the injured individual, the primary practical consequence is that he lacks the power to enforce obligations or remedy violations; the effectiveness of the rule of law is dependent on the willingness of the state to seek a sanction for the violation of the rule.

The statement that individuals do not have rights under international law is thus best understood as a statement that individuals do not under international law have what might be called secondary or remedial rights, as distinguished from primary rights. The distinction between primary and secondary rights derives from that between primary and secondary rules of law. Primary rules in municipal legal systems are those under which "human beings are required to do or abstain from certain actions, whether they wish to or not." 23 Secondary rules are "in a sense parasitic upon" primary rules. ${ }^{24}$ They include rules that specify the consequences of violations of the primary rules. ${ }^{25}$ A secondary or remedial right is thus a right to obtain a remedy or sanction

corporations, municipalities, and states) have rights and duties under municipal law. See id. at $53-54$.

21. See Carl A. Nbrgaard, The Position of the Individual in International Law 35 (I962); Rosalyn Higgins, Conceptual Thinking About the Individual in International Law, 24 N.Y.L. Sch. L. Rev. II, I3 (I978); George Manner, The Object Theory of the Individual in International Law, $46 \mathrm{Am}$. J. Int'l L. 428, 428 (1952). For other discussions of this aspect of the classic model, see Charles G. Fenwick, International Law 32, 86-87 (2d ed. 1934); 1 L. Oppenheim, International Law 2, 17-19, 456-63 (3d ed. I920).

22. See, e.g., C.F. Amerasinghe, Local Remedies in International Law 59-60 (I990); Edwin M. Borchard, Diplomatic Protection of Citizens Abroad 29-32 (I915).

23. H.L.A. Hart, The Concept of Law 78-79 (196I).

24. Id. at 79.

25. See id. at 95 . Hart defined secondary rules broadly to include not only those relating to remedial rights, but also rules regarding how primary rules may be recognized, promulgated, and modified. It may be that only states have secondary rights (or powers) under international law for purposes of these other types of secondary rules. 
upon the violation of a primary right; a primary right is one that does not arise from a prior breach of a legal duty. ${ }^{26}$

The view that individuals lack rights under international law reflects the sanctionist view of law, under which the existence of a right turns on the power of the right-holder to set in motion on his own behalf the machinery of the legal system for enforcing obligations and sanctioning departures from them. ${ }^{27}$ This understanding of the concept of a legal right has a venerable lineage in Anglo-American law. Evidence of a sanctionist understanding of law can be found among the writings of the Framers of our Constitution. ${ }^{28}$ The sanctionist position was also a tenet of the positivists of the Nineteenth Century school of analytical jurisprudence. John Austin considered the "nearest to a true definition" of the term "right" to be "the capacity or power of exacting from another or others acts or forebearances."29 Similarly, Professor Corbin, following Hohfeld, defined a right as "the legal relation of A to $\mathrm{B}$ when society commands action or forbearance by $\mathrm{B}$ and will at the instance of $A$ in some manner penalize disobedience."30 Professor Stone

For present purposes, however, it is sufficient to consider the status of individuals as holders of secondary rights in the more limited sense of remedial rights.

26. See Arthur L. Corbin, Rights and Duties, 33 Yale L.J. 501, 515-16 (1924); see also Arthur L. Corbin, Legal Analysis and Terminology, 29 Yale L.J. 163, 171 (1919) [hereinafter Corbin, Legal Analysis and Terminology] (defining a secondary right as "[a] right resulting from some operative fact that was a violation of some precedent right," and a primary right as "[a] right resulting from some operative fact that was not itself a violation of some precedent right"). Similarly, Professor Monaghan defines primary rules as those "that govern persons independently of litigation." Henry Paul Monaghan, Federal Statutory Review Under Section 1983 and the APA, 91 Colum. L. Rev. 233, 249 (1991). Following Hart and Sacks, see Henry M. Hart, Jr. \& Albert M. Sacks, The Legal Process: Basic Problems in the Making and Application of Law 153 (tent. ed. 1958), he denominates a "remedial right" what Corbin calls a "secondary right." Austin uses the terms "sanctioning" rights and "secondary" rights synonymously to signify rights that "are consequences of delicts," which he defines, in turn, as "[a]cts, forebearances, and omissions, which are violations of [primary] rights or duties." John Austin, Lectures on Jurisprudence: The Philosophy of Positive Law 44-45 (4th ed. 1873). He divides "sanctioning (secondary)" rights into two categories: "sanctioning (or preventive)" and "remedial (or reparative)." Id. at 45.

In this Article, I shall use the term "secondary rights" to refer to both remedial and sanctioning rights. The term will refer to the right to enforce primary rights in advance of a violation and the right to obtain remedies after a violation. The term "secondary right" is more familiar in the international law literature than the terms "remedial" or "sanctioning" right. See, e.g., Louis Henkin et al., International Law 520 (2d ed. 1987). Also, for the sake of simplicity, the term "enforcement," as used herein, refers not only to preventing or terminating a violation of a law, but also to obtaining a remedy for the violation of the law.

27. Lloyd calls this the "extreme sanctionist view of law" and disagrees with it. Dennis Lloyd, The Idea of Law 313 (1964). Katz espouses the view and acknowledges the label. Al Katz, The Jurisprudence of Remedies: Constitutional Legality and the Law of Torts in Bell v. Hood, 117 U. Pa. L. Rev. 1, 36 (1968).

28. See infra notes $62-66$ and accompanying text.

29. Austin, supra note 26 , at 410 .

30. Corbin, Legal Analysis and Terminology, supra note 26, at 167 (emphasis 
likewise maintains that a thing ${ }^{31}$ can be considered a holder of legal rights only if three criteria are satisfied: "[F]irst, that the thing can institute legal actions at its behest; second, that in determining the granting of legal relief, the court must take injury to it into account; and, third, that relief must run to the benefit of it." 32

This sanctionist understanding of the terms "law" and "right" is also reflected in Supreme Court decisions throughout our history. Chief Justice Marshall wrote in Marbury v. Madison:33 "The government of the United States has been emphatically termed a government of laws, and not of men. It will certainly cease to deserve this high appellation, if the laws furnish no remedy for the violation of a vested legal right."34 Justice Holmes ridiculed the concept of an unenforceable right in The Western Maid:35 "Legal obligations that exist but cannot be enforced are ghosts that are seen in the law but that are elusive to the grasp."36 Justice Stevens observed that, unless we recognize individual remedies for violations of the Bill of Rights, "the Bill of Rights should be renamed." 37 These writers and jurists would deny that individuals have a legal right under international law, even if international law requires the state to treat them in a particular way, if international law does not recognize their power to employ the system's machinery for enforcing the rule and sanctioning departures from it.

Other scholars argue that individuals may be said to have a right even if the legal system does not recognize their power to initiate legal actions or otherwise obtain relief at their own behest. ${ }^{38}$ The Permanent Court of International Justice has stated that "it is scarcely necessary to point out that the capacity to possess civil rights does not necessarily imply the capacity to exercise those rights oneself."39 Hart and Sacks have little trouble recognizing the existence of a primary

added). Corbin stated that his definitions were "in large part based upon" Hohfeld's. 1d. at 163 .

31. Stone argues that society should recognize inanimate objects as holders of legal rights. He acknowledges, though, that under existing law such objects were not holders of legal rights, as he defined the term. See Stone, supra note 20 , at 53-54.

32. 1d. at 11 .

33. 5 U.S. (1 Cranch) 137 (1803).

34. 1d. at 163 .

35. 257 U.S. 419 (1922).

36. 1d. at 433 .

37. United States v. Leon, 468 U.S. 897, 978 (1984) (Stevens, J., dissenting); see also First Nat'l Bank v. Missouri, 263 U.S. 640, 660 (1924) ("To demonstrate the binding quality of a statute but deny the power of enforcement involves a fallacy made apparent by the mere statement of the proposition, for such power is essentially inherent in the very conception of law.").

38. See, e.g., Hersch Lauterpacht, International Law and Human Rights 27-29 (1973); Louis Henkin, International Human Rights as "Rights," 1 Cardozo L. Rev. 425, 446 (1979).

39. Appeal from a Judgment of the Hungaro-Czechoslovak Mixed Arbitral Tribunal (Peter Pázmány Univ. v. Czech.), 1933 P.C.I.J. (ser. A/B) No. 61, at 231 (Dec. 15). 
right even if it is unaccompanied by a remedial right. ${ }^{40}$ They contrast a "primary right" with a "remedial right of action," which they describe as a "very different legal animal." 41 They criticize Hohfeld and Corbin for "encourag[ing] . . . confusion [between a primary claim to a performance and a remedial capacity to invoke a sanction for non-performance] by seeming to suggest that the right and the right of action necessarily went together so that if there was no right of action there was no primary right in a genuine sense to begin with, and vice versa." 42

For purposes of the present inquiry, we need not join the debate about whether the object of a primary duty may be said to have a legal right if the legal system does not give him a secondary or remedial right. We may even agree with the sanctionists that a rule not accompanied by a sanction creates moral rather than legal rights. ${ }^{43}$ For present purposes, it suffices merely to recognize that the term "right"-a term that is "incorrigibly multifarious in actual usage"44_admits of both significations. This permits us to square the two premises introduced above as follows: The classic model maintains only that individuals do not have rights under international law in the sanctionist sense, that is, individuals lack secondary rights under international law.45 But the

40.

Such a right, in strictness, is a valid claim to the personal benefit of the performance of a legal duty, not deriving from any default (through breach of duty or defective exercise of power) occurring in any precedent legal position. Usually the right, if there is one in any particular private person, is the mere obverse of the duty.

The breach of a primary private duty may or may not give rise, by operation of law, to a remedial privale duty.

Hart \& Sacks, supra note 26, at 153.

41. Id. at 152.

42. Id.

43. See infra note $61-65$ and accompanying text.

44. Hart \& Sacks, supra note 26 , at 151 ; accord 4 Roscoe Pound, Jurisprudence 56 (I959) ("There is no more ambiguous word in legal and juristic literature than the word right."); Monaghan, supra note 26, at 249; cf. David F. Cavers, A Critique of the Choiceof-Law Problem, 47 Harv. L. Rev. 173, 175-76 (1933) ('[O]ne may now wonder how any juristic construct such as 'right' could have been accepted as fundamental in the explanation of any important aspect of judicial activity.").

45. Indeed, the statement that individuals do not have rights under international law would be true only if the term "right" were understood in an extreme sanctionist sense. International law includes not only rules requiring the state to behave in certain ways towards individuals, but also rules requiring the state to afford the individual certain remedies domestically if that obligation is violated. Thus, a treaty might obligate parties not only to behave in a given way towards individuals, but also to afford individuals a domestic judicial remedy in certain circumstances. See infra note 319 and accompanying text. This has satisfied some scholars who hold the sanctionist view of law that individuals do have rights under international law. See Hans Kelsen, Principles of International Law 140 (1952). A defender of the classic view, however, would maintain that individuals lack rights under international law even in such circumstances 
statement that individuals may enforce a treaty in our domestic courts only if it gives them rights as a matter of international law is true only if the term "right" is understood in the sense of a primary right simpliciter-that is, a primary claim to performance of a duty not necessarily accompanied by the power to enforce the primary right, or obtain a remedy for its violation, through the system's legal machinery.

If the classic model accurately described all rules of international law throughout our history, it would be simple to demonstrate that the domestic enforceability of treaties has never in our history turned on whether the treaty conferred rights on individuals in the sanctionist sense as a matter of international law. Treaties under the classic model never confer rights on individuals as a matter of international law. If individuals' ability to enforce treaties domestically turned on whether they possessed such rights, individuals would never be able to enforce treaties in our courts. The many cases in which individuals have successfully enforced treaties in our courts throughout our history show that the enforceability of a treaty domestically does not turn on whether the treaty confers rights on individuals under international law.

because, in the absence of domestic incorporation of the international law rule requiring the remedy, the individual does not in fact possess a remedy obtainable in the domestic courts. If domestic law does incorporate the international rule, the individual's right is afforded by domestic law, not international law. See infra note 321 and accompanying text. Should the state fail to afford a remedy, it would violate international law, but in tbat event only other states, not the individual, would have a remedy under international law. Kelsen does not dispute this last point, see Kelsen, supra, at 140, but he maintains that, when a domestic court affords an individual a remedy that international law obligates the state to afford, it is functioning as an agent of the international order for this purpose; the individual has a "right" under international law, in Kelsen's view, because he possesses both a primary right and a right to obtain a remedy from an "international" tribunal (the domestic court functioning as an international court) for violation of the primary right.

Kelsen's position reflects a monist understanding of the relationship between international and municipal law, under whicb municipal legal systems are viewed as parts of the international legal order, properly addressing only those subjects that international law delegates to them. The extreme sanctionist position, on the other hand, reflects the dualist understanding that international law and domestic law are distinct legal orders and that the rnles of international law do not have any necessary status as law in the domestic legal order, and are not applied by the law-applying officials of that order, except to the extent they have been incorporated into or made relevant by domestic law. This Article argues that, at least with respect to treaties, the Framers held the dualist view regarding the status of international law as law in the absence of domestic incorporation, but adopted the Supremacy Clause to incorporate treaties into municipal law, thus effectively transforming the dualist system into a monist system (with limited exceptions, such as where a treaty exceeds the treaty-making power or is superseded by legislation, see infra note 145). Kelsen's observations do not conflict with this thesis. Kelsen did not claim that the monist theory accurately described how domestic courts in fact view their functions. Indeed, he acknowledged that AngloAmerican judges do not regard themselves as agents of international law, but instead apply international law only to the extent it has been made "part of" American or English law. Kelsen, supra, at 435 \& n.27. 
If the classic position did not in fact accurately describe international law, it would be necessary to consider whether the domestic enforceability of treaties by individuals is explained by any departures from the classic model. In other words, it would be necessary to determine whether treaties are enforceable by individuals in our courts only when, and to the extent that, they fall within an exception to the classic notion that individuals do not have rights-in the sanctionist senseunder international law. Accordingly, I next consider whether, at any time in our history, our conception of international law has diverged from the classic model and, if so, whether any such departures are relevant to the analysis.

\section{B. The Validity of the Classic Model}

Most observers of international law would agree that the past several decades have seen developments in international law that represent a repudiation of many of the premises of the classic model. Most importantly, the past decades have seen the emergence and recognition of norms of international law protecting human rights. These norms impose obligations on states towards individuals as human beings, not just as nationals of other states, and they limit the discretion of states even with respect to their own nationals. The recognition of such norms means that a state's obligations to behave in certain ways towards individuals are no longer thought to be owed to the state of the individual's nationality for the collective benefit of the individuals comprising the state. This development of course represents a significant departure from the premises of the classic statist conception of international law.

Perhaps surprisingly, there has not been a corresponding expansion of the secondary rights of individuals in the international legal order. Although there has been a modest expansion of the right of individuals to enforce international norms affecting them in international fora, ${ }^{46}$ for the most part such secondary rights continue to be enforceable on the international plane only by states. ${ }^{47}$

The expansion of the international law rights of individuals as a result of the emergence of an international law of human rights does not support the conclusion that the enforceability of a treaty by individuals domestically turns on whether the treaty confers rights on individuals as a matter of international law. Those who argue that treaties may be invoked by individuals in our courts only when they confer rights on individuals rely on statements from judicial opinions dating from the

46. See, e.g., Elihu Lauterpacht, Aspects of the Administration of International Justice 67-72 (1991).

-47. See Henkin, supra note 38 , at $438-42$. 
late nineteenth century, ${ }^{48}$ truly the heyday of the classic model. ${ }^{49}$ Yet throughout that period individuals could enforce treaties in our courts. ${ }^{50}$ Thus, at that time, it was not true that individuals could enforce treaties in our courts only if they had rights under the treaty as a matter of international law.

The emergence of an international law of human rights does not justify a different rule. Conceivably, the expansion of international remedies of individuals for violations of interuational human rights norms might justify a corresponding contraction of domestic remedies, on the ground that domestic remedies are no longer necessary. ${ }^{51}$ But if domestic remedies were to be contracted on this ground, the resulting rule would allow individuals to enforce treaties in our domestic courts when they do not have a right under the treaty-in the strict sanctionist sense of the term-as a matter of interuational law. This is, of course, the opposite of the rule that some lower courts have begun to apply. ${ }^{52}$ As a general matter, the international law of human rights today seeks to protect individuals by requiring states to protect such rights in their domestic legal systems. ${ }^{53}$ To rely on the modest expansion of the secondary rights of individuals under international law to hold that treaties are enforceable by individuals domestically only if they are enforceable by individuals internationally would be a perversion of international human rights law. It would reduce the ability of individuals to enforce

48. The decision cited most frequently for this proposition is Head Money Cases, 112 U.S. 580, 598-99 (1884). See, e.g., Diggs v. Richardson, 555 F.2d 848, 850-51 (D.C. Cir. 1976); Dreyfus v. Von Finck, 534 F.2d 24, 29-30 (2d Cir. 1976); Brief of United States in Alvarez, supra note 14, at 34.

49. See, e.g., Akehurst, supra note 20, at 73; Mark W. Janis, An Introduction to International Law 169-70 (1988).

50. See, e.g., United States v. Rauscher, 119 U.S. 407 (1886), written by Justice Miller, the author of Head Money Cases, in which an individual was permitted to rely on a limitation implicit in the extradition treaty between the United States and Great Britain even though Great Britain could have waived the limitation, either before or after the extradition, and any remedy at the international level for the United States' failure to comply with the treaty would have been Great Britain's only. See also cases cited infra notes $258,265,301$. In none of those cases would the individual have had the power to enforce the United States' duty on the international plane. Had the United States violated the obligation, the individual would have had to rely on the state of his nationality to pursue a remedy against the United States. See Banco Nacional de Cuba v. Sabbatino, 376 U.S. 398, 422-23 (1964) ("Because of its peculiar nation-to-nation character the usual method for an individual to seek relief [for a violation of international law] is to exhaust local remedies and then repair to the executive authorities of his own state to persuade them to champion his claim in diplomacy or before an international tribunal.").

51. Even if such a change were justified, the question would remain whether the change should be accomplished by judicial decision, statute, or constitutional amendment. To the extent that the rules concerning enforceability of treaties in our courts have their source in a constitutional provision, a constitutional amendment would appear to be required.

52. See supra note 6 and accompanying text.

53. See Henkin, supra note 38 , at 427-28. 
treaties in the very cases in which the domestic remedy is most needed: when an international remedy is lacking. I accordingly put aside for present purposes the fact that the classic model does not accurately describe the position of the individual in international law in all respects today.

Some scholars who challenge the classic model focus instead on how international law was perceived at the time of the Constitution's adoption. Increasingly, commentators have written that the classic view that individuals are not subjects of international law, and do not have rights and duties thereunder, did not prevail at the time our Constitution was adopted.54 If individuals in I789 were thought to possess legal rights as a matter of international law, then it is possible that the Framers of our Constitution contemplated that individuals would be able to invoke treaties in our courts only when they would have possessed such rights under the treaties as a matter of international law. It might then be contended that the subsequent recognition that individuals do not have rights and duties under international law served to contract the ability of individuals to invoke treaties domestically.

Whatever the merits of the argument that international law as it was understood in 1789 operated on individuals and thus conferred legal rights on them directly, it is not pertinent to the present analysis. Even those who make the argument appear to extend it only to certain categories of international law, and they appear to agree that treaties were not one of those categories. ${ }^{55}$ In any event, the available evidence of the Framers' intent shows that they understood that treaties, as international instruments, operated on states as bodies politic, rather than on individuals. Because sovereign states acknowledged no superior, treaties depended for their enforcement on either the good faith

54. See, e.g., Anne-Marie Burley, The Alien Tort Statute and the Judiciary Act of 1789: A Badge of Honor, 83 Am. J. Int'l L. 46I, 482-85 (1989); Anthony D'Amato, Judge Bork's Concept of the Law of Nations Is Seriously Mistaken, 79 Am J. Int'l L. 92, 103-04 (1985); M.W. Janis, Individuals as Subjects of International Law, 17 Cornell Int'l L.J. 61, 61-64 (1984); Harold Hongju Koh, Transnational Public Law Litigation, 100 Yale L.J. 2347, 2351-53 (1991); Jules Lobel, The Limits of Constitutional Power: Conflicts Between Foreign Policy and International Law, 71 Va. L. Rev. 1071, 1100 (1985); Ruth Wedgwood, The Revolutionary Martyrdom of Jonathan Robbins, 100 Yale L.J. 229, 252 (1990).

55. Thus, Professor D'Amato notes that, though certain rules of international law "appl[ied]" to individuals, treaties in 1789 "app[lied]" only to "political entities." D'Amato, supra note 54, at 104. And Professor Lobel maintains that the "necessary" law of nations derived from natural law was thought to confer rights directly on individuals, see Lobel, supra note 54, at 1080-81 \& n.39, but treaties at the time were not thought to fall within this category. See Vattel, supra note 17, at lxvi (designating treaties and customary law as "arbitrary" law of nations). It is not clear that all of the commentators cited supra note 54 were using the term "right" in its strict sanctionist sense. To the extent that they were not, their differences with the classic model may be largely terminological. See supra notes 38-39 and accompanying text. 
of the parties or war. ${ }^{56}$ In these respects, they considered treaties to be different from laws. Because treaties lacked a legal sanction, they conferred on both states and individuals what a sanctionist would have considered moral rather than legal rights. In declaring treaties to be the law of the land, it was the Framers' intent to afford individuals a domestic legal santion for treaty violations.

\section{The Framers' Intent Regarding the Effect of the Supremacy Clause on Treaties}

The Framers' criticisms of the government established by the Articles of Confederation show that they understood that treaties, as international instruments, operated on states as bodies politic and were enforceable only by military force. They described the Articles as a "mere treaty" for these reasons.

The new government that the Framers established, by contrast, was one of "law": its acts, treaties, and the Constitution were all three declared to be "laws." To the Framers, this meant that all three would be operative on individuals, not just on states, and would be enforceable in the courts. This was the mechanism by which the new government sought to secure compliance with its acts. The Supremacy Clause transformed instruments that had previously been operative on states as political bodies and enforceable only by military force into instruments operative on individuals and enforceable in the courts.

\section{A. The Framers' Views Concerning the Operation of Treaties on Individuals in the Absence of Domestic Incorporation}

The Framers' understanding of the effect of treaties as interuational instruments, and their applicability to individuals in the absence of a domestic rule of law, is shown clearly by the criticisms they leveled at the document that they had convened to modify or amend-the Articles of Confederation. The Articles of Confederation were criticized as ineffective because they operated on the states as bodies politic rather than on individuals and were dependent for their enforcement on military force or the good faith of the parties. For these reasons, the Articles were described as a "mere treaty" 57 between the thirteen statesparties, and they and the acts of Congress-which similarly operated on states rather than individuals-were contrasted with "laws," which, in the Framers' view, by their nature operated on individuals and were enforceable in the courts. ${ }^{58}$

56. See infra part II.A. $1961)$.

57. The Federalist No. 33, at 204 (Alexander Hamilton)(Clinton Rossiter ed.,

58. These criticisms call to mind the familiar criticisms more recently directed at a similar foundational document-the Charter of the United Nations. See Akhil Reed Amar, Of Sovereignty and Federalism, 96 Yale L.J. 1425, 1448 (1987) ("[T]he 'United 
That the Articles and the acts of Congress operated on states as political bodies rather than on individuals was thought by Hamilton to be their principal defect:

The great and radical vice in the construction of the existing Confederation is in the principle of LEGISLATION for STATES or GOVERNMENTS, in their CORPORATE or COLLECTIVE CAPACITIES, and as contradistinguished from the INDIVIDUALS of whom they consist. . . . The consequence of this is that though in theory their resolutions concerning those objects are laws constitutionally binding on the members of the Union, yet in practice they are mere recommendations which the States observe or disregard at their option.

There is nothing absurd or impracticable in the idea of a league or alliance between independent nations for certain defined purposes precisely stated in a treaty ... . and depending for its execution on the good faith of the parties. Compacts of this kind exist among all civilized nations, subject to the usual vicissitudes of peace and war, of observance and nonobservance, as the interests or passions of the contracting powers dictate. ...

If the particular States in this country are disposed to stand in a similar relation to each other ... the scheme would indeed be pernicious. ${ }^{59}$

Though the Articles were laws in theory, they were in practice more analogous to treaties, which also "depend[ed] for [their] execution on the good faith of the parties."60 In words that call to mind Austin's later writings, ${ }^{61}$ Hamilton wrote:

It is essential to the idea of a law that it be attended with a sanction; or, in other words, a penalty or punishment for disobedience. If there be no penalty annexed to disobedience, the resolutions or commands which pretend to be laws will, in fact, amount to nothing more than advice or recommendation. ${ }^{62}$

The Framers' understanding of the distinction between a law and a

States' in 1787 was not much more than the 'United Nations' is in 1987: a mutual treaty conveniently dishonored on all sides.").

59. The Federalist No. 15, at 108-09 (Alexander Hamilton)(Clinton Rossiter ed., 1961).

60. Id. at 109.

61. Austin defined a law as a command backed by sanctions. See Austin, supra note 26, at 90-93. He thus concluded that an obligation not accompanied by a sanction for its violation was not a law properly so called. See id. at 101-02. He questioned the status of international law as law because its commands did not issue from and were not enforced by a determinate body. See id. at 187-89. He accordingly considered that international law belonged more properly to the realm of positive morality. See id.

62. The Federalist No. 15 , supra note 59 , at 110 . 
treaty was spelled out even more clearly by Hamilton in the Federalist No. 33:

A LAW, by the very meaning of the term, includes supremacy. It is a rule which those to whom it is prescribed are bound to observe. This results from every political association. If individuals enter into a state of society, the laws of that society must be the supreme regulator of their conduct. If a number of political societies enter into a larger political society, the laws which the latter may enact, pursuant to the powers intrusted to it by its constitution, must necessarily be supreme over those societies and the individuals of whom they are composed. It would otherwise be a mere treaty, dependent on the good faith of the parties. ${ }^{63}$

In words echoing Hamilton's, Madison too expressed the view that a law, by its nature, requires a sanction, and in this respect differs from a treaty:

A sanction is essential to the idea of law, as coercion is to that of Goverument. The federal system [under the Articles] being destitute of both, wants the great vital principles of a Political Constitution. Under the form of such a constitution, it is in fact nothing more than a treaty of amity of commerce and of alliance, between independent and sovereign States. ${ }^{64}$

The positivist conception of a treaty as morally rather than legally binding is similarly evident in Madison's statement at the Convention that a "league or treaty ... in point of moral obligation might be as inviolable as [a Constitution]" but "[i]n point of political operation" would not be applied by judges if it conflicted with a preexisting law. ${ }^{65}$ Along the same lines, Gouverneur Morris "explained the distinction between a federal and national, supreme, Govt.; the former being a mere compact resting on the good faith of the parties; the latter having a compleat and compulsive operation." 66

That the Articles and the acts of Congress operated on the states as

63. The Federalist No. 33, supra note 57, at 204 (emphasis added).

64. Observations of James Madison (April 1787), in 2 The Writings of James Madison 361, 363 (Gaillard Hunt ed., 1901).

65. 2 The Records of the Federal Convention of 1787, at 93 (Max Farrand ed., rev. ed. 1966) [hereinafter Farrand].

66. 1 Farrand, supra note 65 , at 34 .

That treaties were thought by the Framers to operate on states rather than on individuals is shown further by an exchange at the Convention between Luther Martin and Madison. Martin argued that "the General Govt. was meant merely to preserve the State Governts: not to govern individuals" and that therefore "its powers ought to be kept within narrow limits." 1d. at 437 . Citing Vattel, among others, he maintained that, because "States like individuals were in a State of nature equally sovereign \& free," they should be represented equally in the legislature. Id. Madison countered that "[ $t]$ he fallacy of [Martin's reasoning] lay in confounding mere Treaties . . . with a compact by which an authority was created paramount to the parties, \& making laws for the government of them." Id. at 446. Also at the Convention, Edmund Randolph argued that the Congress as constituted under the Articles were unfit for "Legislation over 
bodies politic, rather than on individuals, and that the confederation lacked the authority to enforce its acts effectively were in theory distinct criticisms. One could conceive of a mechanism for effectively enforcing the acts of the confederation that would not have involved making them operative directly on individuals. But, as George Mason's statement at the start of the Convention shows, the Framers believed the two problems to be related:

[T] he present confederation was not only deficient in not providing for coercion \& punishment agst. delinquent States; but [he] argued very cogently that punishment could not in the nature of things be executed on the States collectively, and therefore that such a Govt. was necessary as could directly operate on individuals, and would punish those only whose guilt required it. 67

Not all of the Framers considered the Articles to be in all respects a "mere treaty." Indeed, the staunchest supporters of a new Constitution argued that the states had already surrendered a portion of their sovereignty and were thus not sovereign in the international sense even under the Articles of Confederation. ${ }^{68}$ But all ascribed the inefficacy of the Articles to the characteristics they shared with treaties. At the Connecticut ratifying convention, William Samuel Johnson, a member of the Constitutional Convention, contrasted the treaty regime subsisting under the Articles with the regime of law contemplated by the Constitution:

Under our old confederation, each State was bound by the most solemn obligations to pay its proportion of the national expense. If any state did not perform what it had so solemnly promised, it became a transgressor. . . . The other states have a right to redress; they have a right by the law of nature and nations to insist upon, and compel a performance. How shall this be done? There is no other way but by force of arms. ...

The Convention saw this imperfection in attempting to

individuals," because they were "not elected by the people but by the Legislatures" of the States, and therefore "they are a mere diplomatic body." Id. at 256.

67. Id. at 34 (emphasis added). Hamilton's statements quoted above, see supra text accompanying notes 59-63, also show the perceived relation between the two problems.

68. For example, responding to the suggestion of some that the delegates to the Convention lacked the power to propose anything other than a federal plan, by which they meant a government in which "the power was exercised not on the people individually; but on the people collectively, on the Slates," Madison noted that "in some instances as in piracies, captures \&c. the existing Confederacy . . . must operate immediately on individuals." Id. at 314; accord id. at 447 . Hamilton made the same point. Id. at 283. These statements are not inconsistent with the Framers' understanding of the distinction between laws and treaties. The thrust of these statements was that the United States "never were independent States, were not such now, \& never could be even on the principles of the Confederation." Id. at 467 (statement of Elbridge Gerry). 
legislate for States, in their political capacity; that the coercion of Law can be exercised by nothing but a military force. They have therefore gone upon entirely new ground. They have formed one new nation out of the individual States. The constitution vests in the general legislature a power to make laws in matters of national concern; to appoint Judges to decide upon these Laws; and to appoint officers to carry them into execution. This excludes the idea of an armed force. The power, which is to enforce these Laws, is to be a legal power vested in proper magistrates. The force, which is to be employed, is the energy of Law; and this force is to operate only upon individuals, who fail in their duty to their country. This is the peculiar glory of the constitution, that it depends on the mild and equal energy of the magistracy for the execution of the Laws. ${ }^{69}$

The Framers, in short, understood that treaties between independent states operated on those states as bodies politic, not on individuals, and were morally binding on those states but enforceable only by force. In these respects, they considered treaties to be different from "laws,"70 which by their nature operated on individuals, had compulsive force, and were enforceable in the courts. ${ }^{71}$

\section{B. The Framers' Intent Concerning the Enforceability of Treaties by Individuals in Domestic Courts Under the Constitution}

The regime established by the Articles was ineffective, in the Framers' view, because the acts of Congress, their treaties, and the Articles themselves, lacked a legal sanction. Like "mere treaties," they were operative on sovereign states, which acknowledged no superior, and they thus depended for their enforcement on the good faith of those states or on military force. The Framers addressed this problem by annexing a sanction to all three. They gave all three the status of municipal law and accordingly made all three enforceable in the domestic courts by and against individuals.

The treaty-making power under the Articles was vested in Con-

69. William Samuel Johnson, Speech in the Connecticut Ratifying Convention, Jan. 4,1788 , reprinted in 15 The Documentary History of the Ratification of the Constitution 248-49 (John P. Kaminski \& Gaspare J. Saladino eds., 1984) (emphasis added).

70. This understanding of "law" is by no means archaic. See Lon L. Fuller, The Forms and Limits of Adjudication, 92 Harv. L. Rev. 353, 372 (1978) ("The object of the rule of law is to substitute for violence peaceful ways of settling disputes.").

71. See also Marbury v. Madison, 5 U.S. (1 Cranch) 137, 170 (1803) ("The province of the court is, solely, to decide on the rights of individuals . ..."); id. at 177 ("It is emphatically the province and duty of the judicial department to say what the law is."); The Federalist No. 22, at 150 (Alexander Hamilton) (Clinton Rossiter ed., 1961) ("Laws are a dead letter without courts to expound and define their true meaning and operation."); The Federalist No. 78, at 467 (Alexander Hamilton) (Clinton Rossiter ed., 1961) ("The interpretation of the laws is the proper and peculiar province of the courts."). 
gress, ${ }^{72}$ and the individual states were prohibited from entering into compacts with other nations. ${ }^{73}$ But the Articles addressed neither the extent to which treaties would have the force of law in the states nor the consequences of violations of treaties by the states. Jefferson and Jay had opined that treaties made by Congress under the Articles of Confederation were of necessity binding on the states and superior to state law, and indeed, in its waning days the Continental Congress passed a resolution to that effect. ${ }^{74}$ But some states had enacted laws conflicting with treaty obligations, and the judges in the states were enforcing these laws rather than the treaties. There was no effective way under the Articles of Confederation to ensure that states did not, either intentionally or unintentionally, violate a treaty provision, or to correct any such violation.

The inability of the central government under the Articles of Confederation to secure compliance by the states with the nation's treaty obligations was among the principal animating causes of the Framers' decision to establish a new government under a new Constitution, rather than simply amend the Articles of Confederation. In introducing the Virginia plan, Edmund Randolph listed prominently among his reasons for proposing a new constitution the fact that the Confederation "could not cause infractions of treaties or of the law of nations, to be punished."75 "If a State acts against a foreign power contrary to the law of nations or violates a treaty, [the Confederation] cannot punish that State, or compel its obedience to the treaty."76 Pinckney also noted in the early days of the Convention that "foreign treaties [had not] escaped repeated violations."77 And James Madison remarked that "[e]xperience had evinced a constant tendency in the States to ... violate national Treaties ... ."78 Indeed, when Madison, in questioning the adequacy of one of the proposed alternatives to the existing system, catalogued the "evils" of the system created by the Articles of Confederation, the first question he asked was:

Will it prevent those violations of the law of nations \& of Treaties which if not prevented must involve us in the calamities of foreign wars? The tendency of the States to these violations has been manifested in sundry instances. The files of Congs. contain complaints already, from almost every nation with which treaties have been formed. Hitherto indulgence has been shewn to us. This cannot be the permanent disposition of foreigu nations. A rupture with other powers is among the

72. See Articles of Confederation, art. 9.

73. See Articles of Confederation, art. 6.

74. See 32 Journals of the Continental Congress 124-25, 177-84 (Mar. 21, 1787) (Roscoe R. Hill ed.).

75. 1 Farrand, supra note 65 , at 19.

76. Id. at 24-25 (James McHenry).

77. Id. at 164 (James Madison).

78. Id. 
greatest of national calamities. It ought therefore to be effectually provided that no part of a nation shall have it in its power to bring them on the whole. The existing confederacy does not sufficiently provide against this evil. ${ }^{79}$

As Madison's remarks indicate, the Framers were concerned about treaty violations because they threatened offending other nations and thus provoking destructive and costly wars. ${ }^{80}$ But the Framers sought to minimize treaty violations not only to avoid calamity, but also to secure for the nation the benefits of agreements with foreign nations, who could not be expected to enter into such agreements if past agreements were continually violated. ${ }^{81}$ Finally, the Framers were concerned not just with the material benefits of complying with treaties, but also the nation's reputation and honor. ${ }^{82}$

79. Id. at 316. Madison went on to say that the New Jersey plan, discussed below, infra notes 86-94 and accompanying text, "does not supply the omission. It leaves the States as uncontrouled as ever." Id. Madison preferred the scheme contemplated in the Virginia plan for ensuring compliance with treaties.

80. See also 4 The Debates in the Several State Conventions on the Adoption of the Federal Constitution 119 (Jonathan Elliott ed., 2d ed. 1881) [hereinafter Elliott's Debates] (statement of William Davie) ("A due observance of treaties . . . is the only means of rendering less frequent those mutual hostilities which tend to depopulate and ruin contending nations."); id. at 279 (statement of Charles Pinckney) ("[T]reaties shall be considered law of the land; and happy will it be for America if they shall be always so considered: we shall then avoid the disputes, the tumults, the frequent wars, we must inevitably be engaged in, if we violate treaties."); The Federalist No. 3, at 42 (John Jay) (Clinton Rossiter ed., 1961) ("The just causes of war, for the most part, arise either from violations of treaties or from direct violence."); infra note 90 (Framers' concern for national security).

81. See 4 Elliott's Debates, supra note 80, at 266 (statement of Charles Pinckney) ("[If treaties had not been considered the law of the land] and any individual state possessed a right to disregard a treaty made by Congress, no nation would have entered into a treaty with us."); Oliver Ellsworth, Speech in the Connecticut Ratifying Convention, Jan. 4, 1788, reprinted in 15 The Documentary History of the Ratification of the Constitution, supra note 69, at 243, 247 ("[T]'reaties are not performed. The treaty of peace with Great-Britain was a very favorable one for us. But it did not happen perfectly to please some of the states: and they would not comply with it. The consequence is, Britain charges us with the breach, and refuses to deliver up the forts on our northern quarter."); see also 1 Farrand, supra note 65, at 433 (Wilson asking "What is the reason that Great Britain does not enter a commercial treaty with us? Because congress has not the power to enforce its observance.").

82. See Henfield's Case, 11 F. Cas. 1099, 1101 (C.C.D. Pa. 1793) (No. 6,360) (Jay, C.J., delivering charge to the jury) ("The peace, prosperity, and reputation of the United States, will always greatly depend on their fidelity to their engagements; and every virtuous citizen ... will concur in observing and executing them with honour and good faith; and that, whether they be made with nations respectable and important, or with nations weak and inconsiderable, our obligation to keep our faith results from our having pledged it ...."); 2 Elliott's Debates, supra note 80, at 490 (statement of James Wilson) ("[The supremacy] clause, sir, will show the world that we make the faith of treaties a constitutional part of the character of the United States; that we secure its [sic] performance no longer nominally, for the judges of the United States will be enabled to carry it into effect ...."); 3 Farrand, supra note 65, at 548 (statement of James Madison) (because of treaty violations, "the Fedl. authy had ceased to be respected abroad"); The 
The inability of the central government to enforce compliance with treaties was just one aspect of a broader deficiency of the Articles: the central government lacked the authority or means to enforce any of its acts, or the Articles themselves. This deficiency was attributed by the Framers to the fact that, like treaties, the Articles and the acts of Congress did not operate on individuals and could not be enforced against the states. ${ }^{83}$ The Framers corrected this problem with respect to treaties in exactly the same way they corrected it with respect to the statutes of the Union and the Constitution itself: they declared all three to be the "supreme Law of the Land," and accordingly operative directly on individuals and enforceable in the courts.

Although there was a consensus at the Convention that measures had to be taken to ensure compliance by the states with treaties as well as the other acts of the central government, the alternative plans introduced at the Convention differed in how they addressed the problem. Under the Virginia plan, which was introduced by Edmund Randolph at the start of the Convention and reflected on this issue the views of James Madison, 84 the legislature would have had the power "to negative all laws passed by the several States, contravening in the opinion of the National Legislature the articles of Union, or any treaties subsisting under the authority of the union."85 The New Jersey plan, introduced by William Patterson as an alternative to the Virginia plan, would have secured compliance by the states with both treaties and statutes through the plan's version of what became the Supremacy Clause:

Resd. that all Acts of the U. States in Congs. made by virtue \& in pursuance of the powers hereby $\&$ by the articles of confederation vested in them, and all Treaties made \& ratified under the authority of the U. States shall be the supreme law of the respective States so far forth as those Acts or Treaties shall relate to the said States or their Citizens, and that the Judiciary of the several States shall be bound thereby in their decisions, any thing in the respective laws of the Individual States to the contrary notwithstanding; and that if any State, or any body of men in any State shall oppose or prevent ye. carrying into execution such acts or treaties, the federal Executive shall be authorized to call forth ye power of the Confederated States, or so much thereof as may be necessary to enforce and compel an

Federalist No. 22, supra note 71 , at 151 (treaty infractions threaten "[t]he faith, the reputation, [and] the peace of the whole Union," and make it less likely that foreign states will "respect and confide in" the United States). Professor Burley has made a similar point concerning the Framers' reasons for desiring compliance with the law of nations generally. See Burley, supra note 54 , at 481-88.

83. See supra notes 58-63 and accompanying text.

84. See Charles F. Hobson, The Negative on State Laws: James Madison, the Constitution, and the Crisis of Republican Government, 36 Wm. \& Mary Q. 215, 219 (1979).

85. I Farrand, supra note 65 , at $21,47,61,225$. 
obedience to such Acts, or an Observance of such Treaties. ${ }^{86}$

The New Jersey plan also called for the establishment of a federal judiciary, and the judiciary under this plan would have been expressly authorized to exercise appellate jurisdiction in all cases requiring "the construction of any treaty or treaties."87 Similarly, the Virginia plan called for the establishment of a federal judiciary, but it would not specifically have conferred jurisdiction over cases involving treaties.

Under both plans, the mechanism for securing compliance with treaties was the same as the mechanism for securing compliance with federal statutes. The proposed mechanisms, however, differed radically from each other. By declaring treaties to be "law," and specifically requiring federal and state courts to apply them in cases before them, the New Jersey plan made treaties operative on individuals and gave the courts the power and the duty to interpret and enforce them. ${ }^{88}$ The Virginia plan instead gave the legislature the power to "negative" state laws if it found them to be inconsistent with a treaty of the United States. At least as initially proposed, state laws were to be inoperative unless and until they were approved by Congress. ${ }^{89}$ Thus, treaties would not themselves have been operative on individuals; first-line responsibility for securing compliance with treaties would have resided in the legislature, which would have determined whether a state law was consistent with the treaty. The judiciaries then would have been required to give effect to the legislative "veto" of the state law, but not to the treaty itself. This may explain why the Virginia plan did not explicitly extend the jurisdiction of the national courts to cases involving treaties. 90

86. Id. at 245 .

87. Under the New Jersey plan, the judiciary was expressly authorized to exercise jurisdiction

in all cases touching the rights of Ambassadors, in all cases of captures from an enemy, in all cases of piracies \& felonies on the high seas, in all cases in which foreigners may be interested, in the construction of any treaty or treaties, or which may arise on any of the Acts for regulation of trade, or the collection of the federal Revenue.

Id. at 244.

88. Under the Virginia plan, as well as the New Jersey plan, the laws of the national government were to operate directly on individuals rather than on the states. See id. at 34, 141. This was a major departure from the approach under the Articles of Confederation. In Patterson's view, the New Jersey plan did not differ from the Virginia plan in this respect. See id. at 251. But the New Jersey plan, unlike the Virginia plan, made treaties operative directly on individuals and relied on the judiciary to give effect to treaty provisions. And the Supremacy Clause, as ultimately adopted, gave the Constitution itself the status of law, whereas the Virginia plan did not.

89. See Hobson, supra note 84 , at 227.

90. See 1 Farrand, supra note 65 , at 231 . The Virginia plan would have given the national judiciary jurisdiction over cases involving "questions which involve the national peace and harmony" as well as cases involving aliens. Id. at 22. The Framers were concerned about treaty violations by the states because such violations could provoke war. See id. at 19, 24-25; see also supra note 80 (noting the dangers of continued treaty 
The proposed legislative negative of state laws was rejected by the Convention. ${ }^{91}$ Immediately after the rejection of this proposal, a version of the Supremacy Clause identical in substance to the first sentence of the clause quoted above was taken up. ${ }^{92}$ This resolution was agreed to without any discussion. ${ }^{93}$ The Framers thus opted for a judicial negative over a legislative negative. The rejection of the Virginia plan thus reflects a decision not to make the legislature the primary interpreter and enforcer of treaties against the states, and the adoption of the Supremacy Clause represents a decision to vest this power and duty in the courts. ${ }^{94}$

violations to national security). Thus, the national judiciary would presumably have had jurisdiction under this provision to review cases in which the states enforced a state law that the federal legislature had negatived as violative of a treaty. But there was nothing in the Virginia plan making treaties themselves operative on individuals or preemptive of inconsistent state laws.

91. See 2 Farrand, supra note 65 , at 28 . The Convention debates disclose three objections to the proposal. First, it was observed that this provision would "be terrible [i.e., offensive] to the States," id. at 27, and "it would disgust all the states," id. at 28. Second, some perceived a logistical problem: "Shall all the laws of the States be sent up to the Genl. Legislature before they shall be permitted to operate?" Id. at 27. When the proposal was revived later, George Mason expanded upon this logistical issue, "wish[ing] to know how the power was to be exercised. Are all laws whatever to be brought up? Is no road nor bridge to be established without the Sanction of the General Legislature? Is this to sit constantly in order to receive \& revise the State Laws? He did not mean by these remarks to condemn the expedient, but he was apprehensive that great objections would lie agst. it." Id. at 390 . The proposal this time was withdrawn. See id. at 392. Finally, the power was perceived to be unnecessary. Roger Sherman noted that "the Courts of the States would not consider as valid any law contravening the Authority of the Union, and which the legislature would wish to be negatived." Id. at 27. Sherman also observed that "[s]uch a power involves a wrong principle, to wit, that a law of a State contrary to the articles of the Union, would if not negatived, be valid \&c operative." Id. at 28. And Gouverneur Morris stated that "[a] law that ought to be negatived will be set aside in the Judiciary departmt. and if that security should fail; may be repealed by a Nationl. law." Id. These remarks appear to assume that the Supremacy Clause would be adopted. See infra note 94 .

92. The resolution read as follows:

[T] hat the Legislative acts of the U.S. made by virtue \& in pursuance of the articles of Union, and all treaties made \& ratified under the authority of the U.S. shall be the supreme law of the respective States, as far as those acts or treaties shall relate to the said States, or their Citizens and inhabitants-\& that the Judiciaries of the several States shall be bound thereby in their decisions, any thing in the respective laws of the individual States notwithstanding.

Id. at 28-29.

93. Curiously, it was the Virginia plan's proposal for defining the jurisdiction of the federal judiciary-extending such jurisdiction to "cases . . . involv[ing] the National peace and harmony"- that was agreed to at this point, also without discussion. Id. at 39. This provision would presumably have conferred jurisdiction over cases involving treaties. See supra note 90.

94. That the legislative negative was thought by some to be unnecessary, see supra note 91, does not mean that the Framers considered treaties to be operative on individuals and enforceable in the courts even in the absence of the Supremacy Clause. When these remarks were made, the Supremacy Clause had already been proposed 
The foregoing resolutions were referred by the Convention to the Committee of Detail. The draft Constitution reported by that Committee mentioned treaties in several provisions. The version of the Supremacy Clause that was reported by the Committee was identical to the one approved by the Convention. ${ }^{95}$ The Committee's report defined the jurisdiction of the Supreme Court to "extend to all cases arising under laws passed by the Legislature of the United States; to all cases affecting Ambassadors, other Public Ministers and Consuls; ... to all cases of Admiralty and maritime jurisdiction; to controversies . . . between a State or the Citizens thereof and foreign States, citizens or subjects."96 Although the jurisdiction of the Supreme Court was not expressly extended to cases arising under treaties, most cases involving treaties could have been expected to fall in one of those categories. Finally; the Legislature was given the power " $[t]$ o call forth the aid of the militia, in order to execute the laws of the Union, enforce treaties, suppress insurrections, and repel invasions ...."97

This last provision was amended to delete the words "enforce treaties" as redundant, as treaties were declared to be "laws" in the Supremacy Clause. ${ }^{98}$ The Supremacy Clause was amended to add "This Constitution" as among the "supreme Laws of the several States,"99 and to revise the reference to treaties to read as follows: "all treaties made, or which shall he made," under the authority of the United States. ${ }^{100}$ The latter change was designed to make it clear that treaties entered into before the adoption of the Constitution were also to be the "supreme law of the several States."101 The current wording of the clause was chosen by the Committee of Style and was not the subject of discussion. The clause reads as follows:

(indeed, a version of the Supremacy Clause was proposed by Pinckney contemporaneously with the introduction of the Virginia plan). The statements to the effect that the legislative negative was unnecessary thus apparently assumed that the Supremacy Clause would be adopted. When the negative proposal was reintroduced, Sherman again called it "unnecessary," this time explicitly relying on the Supremacy Clause. See 2 Farrand, supra note 65, at 390. Some of the statements-such as Sherman's statement that the legislative negative proposal involved a "wrong principle," see supra note 91 -might also be understood as arguments in favor of the Supremacy Clause as well as against a legislative negative. In any event, given the general understanding that treaties were not thought to operate on individuals, the need to declare them operative as law on individuals and enforceable in the courts was obviously greater than the need to declare federal legislation to be law. See 4 Elliott's Debates, supra note 80 , at 160 (statement of William Davie) ("[T]he general government ought to legislate upon individuals, instead of states. Its laws will otherwise be ineffectual, but particularly with respect to treaties.").

95. See 2 Farrand, supra note 65 , at 183.

96. Id. at 186.

97. Id. at 182 .

98. Id. at 389-90.

99. Id. at 381-82.

100. Id. at 417 .

101. Id. 
This Constitution, and the Laws of the United States which shall be made in Pursuance thereof; and all Treaties made, or which shall be made, under the Authority of the United States, shall be the supreme Law of the Land; and the Judges in every State shall be bound thereby, any Thing in the Constitution or Laws of any State to the Contrary notwithstanding. ${ }^{102}$

The clause defining the jurisdiction of the federal courts was then amended to parallel the Supremacy Clause. ${ }^{103}$ The clause thus amended extended the jurisdiction of the Supreme Court to "all Cases, in Law and Equity, arising under this Constitution, the Laws of the United States, and Treaties made, or which shall be made, under their Authority."104

Thus, in the end, the Framers adopted the very same mechanism for enforcing treaties, federal statutes, and the Constitution itself. It consisted of the Supremacy Clause and its corollary in Article III. The Supremacy Clause gave all three the status of law and instructed the judges in every state to give them effect. The Supreme Court was given appellate jurisdiction over cases arising under all three to monitor state court compliance with the clause. The Constitution thus makes judges the primary enforcers of all three categories of law. ${ }^{105}$

Today, it is recognized that the judicial power and duty to review the acts of the states and the other branches of the federal goverument for conformity with the Constitution springs from the Supremacy Clause's designation of the Constitution as law. ${ }^{106}$ The Articles were considered by the Framers to be a "mere treaty" insofar as they operated on states rather than individuals and were not judicially enforceable. They were a political document allocating powers among political entities but not conferring judicially enforceable rights. By transforming our foundational document from a "mere treaty" into a "law," the Framers made it enforceable by individuals in the courts. The Supremacy Clause accomplished the very same thing with respect to treaties. The clause transformed them from "mere treaties"-in the international sense-into laws. It altered-or made irrelevant-for domestic purposes those attributes of treaties that distingnished them

102. U.S. Const. art. VI, cl. 2.

103. 2 Farrand, supra note 65 , at 432.

104. U.S. Const. art. III, $\S 2$, cl. 1.

105. Although the Constitution also authorized the use of the militia to enforce the three categories of federal laws against recalcitrant states, the courts were chosen as the primary agencies for the construction and enforcement of treaties.

106. See Marbury v. Madison, 5 U.S. (1 Cranch) 137, 177 (1803) (deriving court's power to review acts of the legislature for conformity with the Constitution from the fact that it is the "province and duty of the judicial department to say what the law is"); Edward S. Corwin, Marbury v. Madison and the Doctrine of Judicial Review, in 1 Selected Essays on Constitutional Law 128, 146-47 (Edward Barrett ed., 1938); Henry P. Monaghan, Constitutional Adjudication: The Who and When, 82 Yale L.J. 1363, 1365 (1973) [hereinafter Monaghan, Constitutional Adjudication]; James Wilson, I The Works of James Wilson 329-30 (Robert Green McCloskey ed., 1987). 
from laws: it made them operative on individuals and enforceable in the courts by individuals.

That the Constitution made treaties operative on individuals and enforceable in the courts is shown further by the Framers' statements during the ratification debates. Hamilton wrote in The Federalist No. 22 that "[ $t]$ he treaties of the United States, to have any force at all, must be considered as part of the law of the land. Their true import, as far as respects individuals, must like all other laws, be ascertained by judicial determinations."107 Anti-Cincinnatus, defending the Supremacy Clause, wrote that

public treaties become the law of the land in that being made by constitutional authority, i.e., among us, by those whom the people themselves have authorized for that purpose, are in a proper sense their own agreements, and therefore as laws, bind the several states, as states, and their inhabitants, as individuals to take notice of and govern themselves according to the articles and rules which are defined and stipulated in them: as law of the land they bind to nothing but a performance of the engagements which they contain. ${ }^{108}$

And Brutus, criticizing Article III, conceded that he could "readily comprehend what is meant by deciding a case under a treaty. For as treaties will be the law of the land, every person who has rights or privileges secured by treaty, will have aid of the courts of law, in recovering them."109 William R. Davie, a member of the Federal Convention, described the effect of the Supremacy Clause and the purpose of the grant of federal jurisdiction over cases "arising under" treaties to the North Carolina ratifying convention as follows:

It was necessary that treaties should operate as laws upon individuals. They ought to be binding upon us the moment they are made. They involve in their nature not only our own rights, but those of foreigners. If the rights of foreigners were left to be decided ultimately by thirteen distinct judiciaries, there would necessarily be unjust and contradictory decisions. If our courts of justice did not decide in favor of foreign citi-

107. The Federalist No. 22, supra note 71 , at 150 (emphasis added).

108. Anti-Cincinnatus, Northampton Hampshire Gazette, Dec. 19, 1787, reprinted in 15 The Documentary History of the Ratification of the Constitution, supra note 69, at 36,38 . This statement suggests an understanding of the Supremacy Clause as merely declarative of the inherent status of treaties as law in a democracy: because in a democracy the people are sovereign, and because treaties are made on behalf of the sovereign, the treaties entered into by a democratic government bind the people. Cf. infra note 120 (describing similar view of James Wilson). Under such a theory, the status of treaties as law derives not from the Supremacy Clause but from the nature of democratic government. Nevertheless, even under this theory, treaties are operative as law on individuals as a result of domestic law (the Constitution, which establishes a democratic system of government), not international law.

109. Brutus XIII, New York Journal, Feb. 21, 1788, reprinted in 16 The Documentary History of the Ratification of the Constitution, supra note 69, at 172 . Brutus had difficulty understanding what was meant by a case "in equity" under a treaty. 
zens and subjects when they ought, it might involve the whole Union in a war . . . .110

The Convention and ratification debates, and contemporaneous statements, show clearly that the Framers were concerned about treaty violations because they could provoke wars, deter other nations from entering into beneficial agreements with us, and adversely affect the nation's reputation. To prevent or remedy treaty violations before they produced these consequences, they declared treaties to be the "supreme Law of the Land." By so doing, the Framers intended to make treaties operative on individuals and enforceable in the courts in cases between individuals. They considered a judicial sanction to be an essential attribute of a law, and by giving treaties the status of law they contemplated that the judiciary would provide such a sanction and thus prevent or remedy any violation before it escalated to the international arena.

\section{Early Judicial Construction}

The Supreme Court's first major treaty decision, Ware v. Hylton, ${ }^{111}$ further demonstrates the Framers' understanding of the Supremacy Clause's effect on treaties. This decision provides additional evidence that the Framers understood that the Supremacy Clause transformed what would otherwise have been merely moral obligations into legal ones enforceable by individuals in our courts.

Ware $v$. Hylton concerned the effect of the 1783 Treaty of Peace with Great Britain on debts that had been owed to British citizens by Virginia citizens, but which had been discharged pursuant to a 1777 state law permitting the discharge of such debts through the payment of Virginia currency into the Virginia Treasury. The fourth article of the Treaty of Peace provided that "[i]t is agreed, that creditors, on either side, shall meet with no lawful impediment to the recovery of the full value, in sterling money, of all bona fide debts heretofore contracted."112 The British plaintiff argued that this article operated to revive the debt owed to him by the Virginian defendant, a debt that had been discharged under Virginia law before 1783 when the defendant paid the amount owed into the Virginia Treasury pursuant to the 1777 law.

In deciding that issue, Justice 1redell, sitting as Circuit Justice, first considered the effect of the treaty on the states' domestic laws before the adoption of the Constitution. ${ }^{113}$ He understood the law on this

110. 4 Elliott's Debates, supra note 80 , at 158 (emphasis added).

111. 3 U.S. (3 Dall.) 199 (1796).

112. Id. at 277.

113. See id. at 271-73. In that connection, he drew a distinction between executed and executory treaty provisions. Executory provisions were those in which "a nation promises to do a thing." Id. at 272. Such provisions are "to be carried into execution, in the manner which the Constitution of that nation prescribes." Id. As discussed 
subject under the Articles of Confederation to be the same as it was in Great Britain, which he described as follows:

[I]t is an invariable practice in that country, when the king makes any stipulation [in a treaty] of a legislative nature, that it is carried into effect by an act of parliament. The parliament is considered as bound, upon a principle of moral obligation, to preserve the public faith, pledged by the treaty, by passing such laws as its obligation requires; but until such laws are passed, the system of law, entitled to actual obedience, remains, de facto, as before. ${ }^{114}$

Thus, a treaty provision agreeing that the tariff on wines from France will be X would not in Great Britain itself establish the tariff as X. An act of Parliament was necessary to establish the tariff at $X$. This was so even though the treaty did not say "that the Parliament shall pass laws" to such an effect, but instead by its terms purported to set the tariff itself. ${ }^{115}$ In other words, in Great Britain, a treaty purporting to set a tariff at a certain level in fact constitutes only an agreement to set the tariff at that level; the treaty will not be applied by the courts or other domestic institutions without implementation by the domestic law-making authority. ${ }^{116}$

Justice Iredell next discussed the effect of the adoption of the Constitution. He observed that the Supremacy Clause was adopted to address the position of some of the states that the Treaty of Peace had no greater effect on their laws than on the laws of Great Britain. The treaty "was binding in moral obligation, but could not be constitutionally carried into effect (at least in the opinion of many,) so far as legislation then in being constituted an impediment, but by a repeal." The Supremacy Clause was adopted "to obviate this difficulty." The effect of the Supremacy Clause, in Justice Iredell's view, was to render all otherwise "executory" treaty provisions "executed."

Under this constitution, therefore, so far as a treaty constitutionally is binding, upon principles of moral obligation, it is

below, in Great Britain, any stipulations of a legislative nature (that is those that contemplate a rule operative on individuals and enforceable in court) required an act of Parliament. See infra notes 114-117 and accompanying text. In Justice lredell's view, the Supremacy Clause obviated this distinction in the United States. See infra note 117 and accompanying text. Chief Justice Marshall later partially resurrected it in Foster v. Neilson, 27 U.S. (2 Pet.) 253, 314 (1829).

114. 3 U.S. ( 3 Dall.) at 274. Iredell's statement that treaties in Great Britain established moral though not legal obligations recalls John Austin's characterization of international law as belonging to the realm of morality and not that of law, properly understood. See supra note 61 .

115. See 3 U.S. (3 Dall.) at 275.

116. See id. at 274-75. Iredell appeared to believe that the British system was shared by most other countries. See infra note 117 . Thus his description of the British system was a description of the effect of treaties in domestic legal systems generally (in the absence of a supremacy clause). This view was apparently shared by Chief Justice Marshall. See Foster, 27 U.S. (2 Pet.) at 314; infra note 125 and accompanying text. 
also, by the vigor of its own authority, to be executed in fact. lt would not otherwise be the supreme law, in the new sense provided for, and it was so before, in a moral sense. When this constitution was ratified, the case as to the treaty in question stood upon the same footing, as if every act constituting an impediment to a creditor's recovery had been expressly repealed, and any further act passed, which the public obligation had before required, if a repeal alone would not have been sufficient. ${ }^{117}$

Justice Iredell went on to interpret the treaty, and he held that, though it operated of its own force to remove impediments to the collection of debts pending at the time of its ratification, the treaty did not obligate the United States to treat as "revived" debts that by that time had already been discharged. Thus, though the treaty had the force of law in the United States, the law it established was (on its merits) not one that revived the plaintiff's debt.

The Supreme Court, on writ of error, reversed Justice Iredell, but only because he had not interpreted the treaty broadly enough. On the treaty's domestic effect, the Court was in accord with Justice Iredell. Each Justice set forth his reasons separately. Justice Chase, who expressed his views most fully, interpreted the Supremacy Clause as establishing that "every treaty made by the authority of the United States, shall be superior to the constitution and laws of any individual State," and that, consequently, the "laws of any of the states, contrary to a treaty, shall be disregarded." 18 He went on to interpret the treaty, applying general principles of treaty interpretation, and concluded that the 1783 Treaty of Peace obligated the parties not only to disregard preexisting laws that permitted certain debts to be discharged with paper money, but also to treat as "revived" any debts that had been discharged pursuant to such laws before the treaty entered into force. ${ }^{119}$ The other Justices (save Iredell) concurred in this result. ${ }^{120}$

117. 3 U.S. (3 Dall.) at 277. Justice Iredell also noted that the United States Constitution "affords the first instance of any government ... saying, treaties should be the supreme law of the land," thus suggesting that he believed that most other countries in the world followed the British model described above, supra notes 113-116 and accompanying text. Id. at 272.

118. Id. at 237.

119. See id. at $241-42$.

120. See id. at 245, 256. Justice Wilson expressed the view in his opinion that the treaty would supersede the state law even in the absence of the Supremacy Clause. See id. at 281. He did not explain his reasoning, but his lectures of 1790 shed some light on his thinking. See Wilson, supra note 106, at 153, 166-67, 177. Wilson apparently believed that in a democracy, because the people are sovereign, government officials enter into treaties on their behalf as their agents. Consequently, treaties are binding not just on the state as a political body, but on the people themselves (the principals). In monarchies, however, treaties would be binding only on the sovereign. See id.; see also supra note 108 (describing similar view of Anti-Cincinnatus). Wilson apparently concluded that the Treaty of Peace accordingly directly affected the rights of the individual defendant in Ware (who was a U.S. citizen). His theory could have led him to 
Ware v. Hylton establishes that, when a treaty creates an obligation of a state vis-à-vis individuals, individuals may enforce the obligation in court even though the treaty does not, as an international instrument, confer rights directly on individuals of its own force. As Justice lredell recognized, in Great Britain individuals would not have had rights under the treaty enforceable in court, yet the Court held that, by virtue of the Supremacy Clause, the treaty was enforceable by individuals in our courts. Justice lredell held that the treaty did not revive debts that had been discharged before the treaty entered into force because the treaty parties did not intend to require the revival of such debts. ${ }^{121}$ The Court held that the treaty did operate to revive such debts because the parties intended to require each other to revive any such debts. The intent of the parties largely determined the scope of the international obligation established by the treaty; the Supremacy Clause gave the obligation the force of domestic law in the United States, nullified inconsistent state law, and required the courts to give effect to the obligation at the behest of an individual. ${ }^{122}$

Chief Justice Marshall's opinion in Foster $v$. Neilson, ${ }^{123}$ which is considered to be the origin of the doctrine of self-executing treaties, partially resurrected the distinction between executory and executed treaty provisions that Justice Iredell thought had been interred by the Supremacy Clause. The tension between the doctrine of self-executing treaties and the status of treaties as "Law of the Land" is discussed below. ${ }^{124}$ But even Foster supports the conclusion that the Framers did not believe treaties operated directly on individuals as a matter of international law, but that the Supremacy Clause established a different rule in the United States. Chief Justice Marshall wrote:

A treaty is, in its nature, a contract between two nations, not a legislative act. It does not generally effect, of itself, the object to be accomplished, especially, so far as its operation is infraterritorial; but is carried into execution by the sovereign power of the respective parties to the instrument. In the United States, a different principle is established. Our constitution declares a treaty to be the law of the land. It is, consequently, to be regarded in courts of justice as equivalent to an act of the legislature . . . ${ }^{125}$

conclude that, since the individual plaintiff (a British citizen) was the subject of a monarchy, he had no rights directly under the treaty. Wilson instead permitted the plaintiff to maintain his suit. It was apparently sufficient that the treaty directly imposed duties on the defendant; the existence of a correlative right followed.

12I. See 3 U.S. (3 Dall.) at 276.

122. See id. at 236-37, 244-45.

123. 27 U.S. 253 (1829).

124. See infra part III.B.3.

125. Foster v. Neilson, 27 U.S. (2 Pet.) 253, 314 (emphasis added). Marshall extended this last proposition only to treaties that "operate of themselves, without the aid of any legislative provision." Id. This qualification is the source of the doctrine of self-executing treaties, discussed in the next part. 
None of the Supreme Court's subsequent decisions supports the proposition that the ability of individuals to enforce treaties domestically turns on whether the treaty confers rights on them-in the sanctionist sense-as a matter of international law. By making treaties the law of the land, the Framers made treaties enforceable by individuals in our courts when they would not otherwise have been.

\section{Treaty-Based Rights and Remedies of Individuals: A PROPOSED FRAMEWORK}

That the Supremacy Clause makes treaties operative directly on individuals and enforceable in the courts at their behest does not mean that any treaty may be enforced by any individual at any time. The rules specifying whether and when constitutional and statutory adjudication is appropriate, and at whose behest, are no less applicable to treaty adjudication.

In this Part, I outline a framework for determining the circumstances in which treaty provisions may be enforced by individuals in our courts. I propose a framework that is faithful to the text of the Constitution and the intent of the Framers. I place particular significance on the clause's designation of "all" treaties as "supreme Law of the Land" and on the Framers' adoption of the same mechanism for securing compliance with treaties as for securing compliance with federal statutes and the Constitution itself. The framework I propose explains the results in the principal Supreme Court decisions involving treaties, and is consistent with the rationales put forward by the Court for those results, without doing violence to the constitutional text. It is also reasonably consistent with the results of the lower court decisions, and sensitive to the intuitions that appear to have produced those results. ${ }^{126}$

The Supremacy Clause's designation of treaties as law was

126. The framework 1 propose is faithful to the text of the Constitution and the Framers' intent and describes reasonably accurately the legal landscape (particularly the Supreme Court decisions). Like Professor Fallon, 1 believe that, in the event of a conflict between constitutional text and the intent of the Framers, on the one hand, and legal doctrine developed by the courts, on the other, the former should prevail unless the latter has become firmly entrenched. See Richard H. Fallon, Jr., A Constructivist Coherence Theory of Constitutional Interpretation, 100 Harv. L. Rev. 1189, 1237-52 (1987). Thus, I accept the "last-in-time" rule, see infra note 197, even though there is strong (though not conclusive) evidence that the Framers intended that treaties be lexically superior to statutes. See Lobel, supra note 54 (arguing that last-in-time rule is inconsistent with Framers' intent). Compare Peter Westen, The Place of Foreign Treaties in the Courts of the United States: A Reply to Louis Henkin, 101 Harv. L. Rev. $511,512,516$ (1987) (arguing that treaties are lexically superior to statutes but for political question reasons are not enforceable in courts in the face of subsequent conflicting statutes) with Louis Henkin, Lexical Priority or "Political Question": A Response, 101 Harv. L. Rev. 524, 524 (1987) (arguing that the courts regard treaties as equal in stature to statutes). 
designed to avert violations by the United States of its treaty obligations. I shall accordingly focus on the power of individuals to enforce the treaty obligations of the United States, rather than those of other states. Treaties, as international instruments, impose obligations on states, not directly on private individuals. The acts of private individuals may give rise to violations of treaties by the United States if left unredressed and in certain other contexts, and the Framers' remarks show that the Supremacy Clause makes the treaty-based duties of the United States in certain circumstances the duties of private individuals. Elaboration of a theory of treaty-based duties of individuals, however, is beyond the scope of this Article. I shall focus instead on the ability of individuals to enforce treaty obligations of the United States against those entities whose actions are directly controlled by such treaties as a matter of international law: state and federal governments and their officials. Accordingly, the paradigmatic case considered in this section involves a foreign national seeking to enforce in the courts of this country against a state or federal official a treaty provision that he claims requires the United States to act-or refrain from acting-in a way that affects him, or seeking a remedy for a claimed violation of the treaty by the official. ${ }^{127}$

I propose that, in determining whether a treaty is enforceable by an individual, the courts distinguish issues relating to the nature of the obligation imposed by the treaty from issues relating to whether the particular individual before it may enforce the obligation and what remedies he may obtain. I address the former issues in Part III.B. As in the statutory context, a treaty should not be enforceable in court if the treaty does not in fact impose obligations, but is instead precatory or hortatory. Nor should a treaty be enforceable in the courts, even if it contemplates the establishment of obligations towards individuals, if instead of establishing those obligations itself it delegates that responsibility to Congress. Finally, treaty obligations may be unenforceable in the courts because they raise political rather than judicial questions. These are not airtight categories. In fact, they may in the end involve the same issue: precatory or hortatory language in a treaty provision may indicate that the treaty does not itself establish an obligation towards individuals, but delegates that responsibility to Congress, and the latter responsibility may be unenforceable in court because it requires the exercise of political rather than judicial judgment. Whether they are the same or not, the issues differ from the next set of questions in that they focus on the nature of the obligation rather than on its

127. Human rights treaties now obligate the United States to behave in given ways towards its own citizens. The framework proposed in this Article should apply equally when a United States citizen seeks to enforce, or obtain a remedy for the violation of, an obligation of the United States under a human rights treaty. For the sake of simplicity, however, 1 will focus in the text on treaty obligations of the United States towards foreign nationals. 
relationship to the individual before the court. They are, however, analogous to issues that the courts address routinely in determining whether to enforce statutes or the Constitution. I argue that they should be resolved with respect to treaties as they are resolved in those other contexts.

The set of questions I address in Part III.C arises only if the treaty imposes judicially enforceable obligations on the United States. The first issue is whether the individual seeking to enforce the obligation has standing to enforce it. To determine whether a litigant has standing to enforce a statute or a constitutional provision imposing an obligation on the state, the courts ask whether the litigant is an intended beneficiary of the law. I argue that this test should be applied to determine whether a litigant may enforce a treaty domestically. The test that is currently applied for the latter purpose-whether the treaty confers a right on the litigant-results in confusion because of the ambiguity of the term "right." I concluded above that the term "right" in this context must be understood as primary right. The standing rules applied in the statutory and constitutional contexts address whether an individual has a primary right under those laws. These same rules should be applied to determine whether an individual has a primary right under a treaty. The standing question and the primary right question may, and should, be collapsed.

If the treaty imposes an obligation on the state and confers a correlative primary right on an individual, whether that individual may enforce the obligation in court may turn on whether he has a right of action. A right of action is not required when the litigant is relying on the treaty as a defense. If the litigant is seeking affirmative relief, a right of action is necessary but need not be established by the treaty itself. In the category of cases of most concern here, a right of action for certain forms of relief is conferred by federal statutes. In Part III.C.2, I examine the possible bases of rights of action to redress, prevent, or stop treaty violations.

Finally, whether the treaty is being relied on as a defense or as a basis for affirmative relief, the court will have to determine the appropriate remedy. For this purpose, I argue that all treaties incorporate the default rules of customary international law that specify the appropriate remedy for treaty violations and that under the Supremacy Clause, individuals are entitled to those remedies if failure to afford them those remedies would produce or exacerbate a treaty violation by the United States against the state of their nationality. ${ }^{128}$

128. There are of course other issues that courts must address in suits against government officials. If suit is brought in federal court, there must be a statutory basis of federal jurisdiction. Additionally, official immunity may be an obstacle in a suit seeking retrospective relief from the government official. See Paul M. Bator et al., Hart and Wechsler's The Federal Courts and the Federal System 1277-1307 (1988) [hereinafter Hart \& Wechsler]. It should not be an obstacle to a suit seeking prospective 
When a treaty is invoked in court, the court usually addresses what is considered to be a threshold issue distinct from (though perhaps related to) each of the foregoing issues: whether the treaty is self-executing. Before turning to my proposed framework, I examine in section A the so-called doctrine of self-executing treaties to determine how it relates to the issues I will be discussing. I conclude that the doctrine in fact masks a variety of distinct issues that bear on a treaty's enforceability in a given case. These are the same issues that I discuss in the remainder of this Part. The framework I propose is accordingly a substitute for the current doctrine of self-executing treaties. Rather than address these issues through a single doctrine, I propose that the issues be addressed by the courts separately, directly, and selfconsciously.

\section{A. Is There a Doctrine of Self-Executing Treaties?}

A treaty that is not self-executing is, according to the usual definition, a treaty that must be implemented by legislation before it may be applied in the court. But a treaty, like a statute or a constitutional provision, may have to be supplemented by a statute before it may be applied in the courts for any of a number of reasons. At the very least, there has to be a statute creating the court. If suit is brought in a federal court, there has to be a statute giving the court jurisdiction over the subject matter. Legislation may be needed if the law the litigant relies on contemplates the creation of the duty he seeks to enforce but does not itself purport to create the duty. If the law does create the duty, legislation may be required to establish a right of action for damages or for some other form of relief. Rarely will a law invoked by a litigant in court itself address every aspect of the litigant's case.

The term "self-executing," when used outside the treaty context, is sufficiently versatile to describe any of the foregoing deficiencies of the law the litigant relies on. In common usage, the term means accomplishing a certain end ex proprio vigore, or of its own force. The meaning of the statement that a certain law is not self-executing depends on what the end is that the speaker has in mind. The statement is ambiguous if that end is not specified. The same law may be self-executing in one sense and not in another. The Commerce Clause, for example, has been described as self-executing because it, of its own force, places lim-

injunctive relief against the official. Eleventh Amendment immunity may be an obstacle if the suit in federal court seeks retrospective relief from the state itself, as distinguished from the officer, unless Congress has abrogated the immunity or the state has waived it. It will not be an obstacle, however, if the suit seeks prospective injunctive relief from the officer. See id. at I179-1221. Sovereigu immunity will bar suits against the United States unless Congress has waived the immunity, as it has done for suits under the Federal Tort Claims Act and the Administrative Procedure Act. See id. at 1213-21; see infra notes 275,295 . On the applicability of sovereign immunity in suits against federal officers, see infra note 295 . These issues will be discussed in this Article only in passing. 
its on the states' legislative power. ${ }^{129}$ But the same clause can be described as not self-executing because it does not itself establish remedies for its violation. ${ }^{130}$ The Takings Clause has been described as self-executing because it itself establishes a remedy for its violation ("just compensation"), ${ }^{131}$ but it might be described as not self-executing because it does not itself confer jurisdiction on the courts, ${ }^{132}$ or authorize or effectuate a levy of property without judicial intervention, ${ }^{133}$ or abrogate an immunity enjoyed by a particular defendant. ${ }^{134}$

129. See, e.g., Wardair Canada Inc. v. Florida Dep't of Revenue, 477 U.S. 1, 7 (1986); South-Central Timber Dev., Inc. v. Wunnicke, 467 U.S. 82, 87 (1984); Vicki C. Jackson, One Hundred Years of Folly: The Eleventh Amendment and the 1988 Term, 64 S. Cal. L. Rev. 51, 66 (1990).

Similarly, Section 1 of the Fifteenth Amendment has been described as "selfexecuting" in the sense that it limits of its own force the power of the states (as well as the federal government). See NAACP v. New York, 413 U.S. 345, 350 (1973); South Carolina v. Katzenbach, 383 U.S. 301, 325 (1966).

130. See Alfred Hill, Constitutional Remedies, 69 Colum. L. Rev. 1109, 1112 (1969) (asking " $t$ ]o what extent is the Constitution self-executing in regard to affirmative remedies?").

In Dennis v. Higgins, 111 S. Ct. 865, 868-73 (1991), the Supreme Court held that section 1983 gives individuals a federal remedy against state officials for violation of the Dormant Commerce Clause, thus suggesting that the clause does not itself afford a remedy. Cf. McKesson Corp. v. Division of Alcoholic Beverages and Tobacco, $110 \mathrm{~S}$. Ct. 2238, 2247-50 (1990) (Due Process Clause requires states in certain circumstances to afford a damages remedy for violation of the Commerce Clause).

131. See, e.g., First Eng. Evangelical Lutheran Church v. County of Los Angeles, 482 U.S. 304, 305 (1987); United States v. Clarke, 445 U.S. 253, 257 (1980); United States v. Testan, 424 U.S. 392,401 (1976).

132. Article IlI has been described as not self-executing in the sense that it does not itself confer jurisdiction on the lower federal courts. See Pennsylvania v. Union Gas Co., 491 U.S. 1, 19 (1989) (plurality opinion); Merrell Dow Pharmaceuticals, Inc. v. Thompson, 478 U.S. 804, 807 (1986).

133. The decisions of the Internal Revenue Service have been described as "selfexecuting" because the IRS "need never go into court to assess and collect the amount owed; it is empowered to collect the tax by nonjudicial means (such as levy on property or salary), without having to prove to a court the validity of the underlying tax liability." United States v. Baggot, 463 U.S. 476, 481 (1983). Of course, even IRS decisions can be described as not self-executing in the sense that an additional executive act may be required to collect the money or take possession of the property in the event of nonpayment after the levy.

134. See Jagnandan v. Giles, 538 F.2d 1166, 1189 (5th Cir. 1976) (Goldberg, J., concurring) (discussing whether Fourteenth Amendment "acts as a self-executing pro tanto repeal of the eleventh amendment's proscription on retroactive money recoveries from the states"), cert. denied, 432 U.S. 910 (1977); Chavous v. South Carolina Coastal Council, 745 F. Supp. 1168, 1171 (D.S.C. 1990) ("[T] he eleventh amendment . . . 'countermanded any judicial inclination to interpret article 111 [of the Constitution] as a self-executing abrogation of state immunity from suit.' " (quoting Laurence H. Tribe, American Constitutional Law \$ 3-25 (2d ed. 1988)), vacated sub nom. Esposito v. South Carolina Coastal Council, 939 F.2d 165 (4th Cir. 1991), petition for cert. filed, 60 U.S.L.W. 3505 (U.S. Dec. 5, 1991) (No. 91-941).

In Atascadero State Hosp. v. Scanlon, 473 U.S. 234, 245-46 (1985), the Court said that a statute that authorizes a remedy against a state does not for that reason abrogate the state's Eleventh Amendment immunity from suit in federal court (thus holding that 
It is recognized that a statutory or constitutional provision may or may not be self-executing in any of the foregoing senses.

The term is just as versatile, and thus just as ambignous, with respect to treaties. An examination of the cases discussing the self-execution question reveals that the self-execution analysis has been used to address a variety of distinct reasons to apply, or not to apply, a treaty in a case. Thus, treaties have been dismissed as not self-executing because they do not impose the obligation on the defendant that the plaintiff claims they impose. ${ }^{135}$ Treaties have been dismissed as not self-executing because the obligations they impose do not give rise to correlative rights in the individuals relying on them. ${ }^{136}$ Courts have dismissed treaties as not self-executing because they do not confer a private right of action, ${ }^{137}$ or because they do not authorize the remedy that the litigants relying on them seek. ${ }^{138}$ Finally, courts have dismissed treaties as not self-executing because the disputes to which they have given rise are not justiciable. ${ }^{139}$ In short, the term "self-executing" has been used in the treaty context to address the same variety of concepts that the term addresses with respect to statutes and constitutional provisions.

These are, of course, distinct issues, and should be addressed by distinct rules, as they usually are with respect to statutory and constitutional claims. But, in treaty cases, the issues have been conflated. The

the creation of a cause of action against a state and the withdrawal of the state's Eleventh Amendment immunity are not the same thing). See also Hilton v. South Carolina Pub. Ry. Comm'n, 112 S. Ct. 560, 565-66 (1991) (distinguishing between creation of right of action against state agency and abrogation of agency's Eleventh Amendment immunity). But cf. Argentine Republic v. Amerada Hess Shipping Corp., 488 U.S. 428, 440-42 (1989), in which the Court blurred the sovereign immunity and right of action issues by holding that certain treaties do not abrogate a foreign state's sovereign immunity because they do not "create private rights of action for foreign corporations to recover compensation from foreign states in United States courts." Id. at 442 . The Court in Amerada Hess did not use the term "self-executing," but it cited cases commonly regarded as self-execution cases. See id. (citing Head Money Cases, 112 U.S. 580, 598-99 (1884) and Foster v. Neilson, 27 U.S. (2 Pet.) 253, 314 (1829)).

135. See, e.g., In re Alien Children Educ. Litig., 501 F. Supp. 545, 590 (S.D. Tex. 1980), aff'd on other grounds sub nom. Plyler v. Doe, 457 U.S. 202 (1982).

136. See, e.g., Diggs v. Richardson, 555 F.2d 848, 850 (D.C. Cir. 1976).

137. See, e.g., Tel-Oren v. Libyan Arab Republic, 726 F.2d 774, 808-10 (D.C. Cir. 1984) (Bork, J., concurring) (dictum); Von Dardel v. Union of Soviet Socialist Republics, 736 F. Supp. 1, 5 (D.D.C. 1990); Handel v. Artukovic, 601 F. Supp. 1421, 1425 (C.D. Cal. 1985); cf. Amerada Hess, 488 U.S. 428 (suggesting that Head Money Cases and Foster v. Neilson, which are commonly regarded as self-execution cases, had something to do with whether the treaty conferred a right of action).

138. See, e.g., Holmes v. Laird, 459 F.2d 1211, 1222 (D.C. Cir.), cert. denied, 409 U.S. 869 (1972).

139. See, e.g., Z \& F Assets Realization Corp. v. Hull, 114 F.2d 464, 470 (D.C. Cir. 1940), aff'd on other grounds, 311 U.S. 470 (1941). The court in this decision did not use the term "self-executing," but the decision has been interpreted as an application of the self-execution doctrine. See, e.g., Tel-Oren, 726 F.2d at 810 (Bork, J., concurring); Dreyfus v. Von Finck, 534 F.2d 24, 29 (2d Cir.), cert. denied, 429 U.S. 835 (1976). 
courts have perceived the term "self-executing" as a term of art relating to a distinct (though amorphous and ill-defined) doctrine of treaty law. They have resolved the various issues by applying a single (though changing) set of criteria. The criteria address to varying degrees many of the issues listed above, but, to the extent they have had a clear conception of the doctrine, the courts have perceived the self-execution issue as distinct from, though perhaps related to, each of those issues. ${ }^{140}$

What Professor Henkin said about the political-question doctrine is an even more apt description of the doctrine of self-executing treaties: the doctrine "is an unnecessary, deceptive packaging of several established doctrines that has misled lawyers and courts to find in it things that were never put there and make it far more than the sum of its parts."141 Recognizing that the term "self-executing" is no more a term of art with respect to treaties than with respect to statutory and constitutional provisions, and that the "doctrine" in fact masks a variety of issues, each of which has its analogue in the jurisprudence of constitutional and statutory adjudication, is the first step in restoring some integrity to this area of the law. The second step, I submit, is to address each of these distinct issues when it arises in a treaty case as it is addressed in a statutory or constitutional case. This includes employing the criteria that are used to address the issue in those other contexts, with appropriate modifications if necessary, but abandoning the "selfexecution" terminology and the criteria that do not bear on the relevant issue. ${ }^{142}$

140. The courts' approach to the self-execution issue in Frolova v. U.S.S.R., 761 F.2d 370, 373-76 (7th Cir. 1985), is typical. The court said that the issue turned on whether the treaty was "intended to be self-executing." Id. at 373. For this purpose, the court said that the following factors should be considered:

(1) the language and purposes of the agreement as a whole; (2) the circumstances surrounding its execution; (3) the nature of the obligations imposed by the agreement; (4) the availability and feasibility of alternative enforcement mechanisms; (5) the implications of permitting a private right of action; and (6) the capability of the judiciary to resolve the dispute.

Id. at 373. Without a clear conception of what the term "self-executing" refers to, however, it is unclear what exactly a court should look for in the language of the agreement or the circumstances surrounding its execution (factors 1 and 2). The last four factors relate to several of the issues discussed below: whether the treaty creates an obligation (factor 3), see infra part III.B.1; whether the obligation raises judicial as opposed to political questions (factor 6), see infra part III.B.3; whether the treaty confers a private right of action (factor 5), see infra part III.C.2; or whether judicial review is precluded by the treaty or a statute (factor 4), see infra note 299 and accompanying text. For a different set of criteria, see People of Saipan v. United States Dep't of Interior, 502 F.2d 90, 97 (9th Cir. 1974), cert. denied, 420 U.S. 1003 (1975).

14I. Louis Henkin, Is There A "Political Question" Doctrine?, 85 Yale L.J. 597, 622 (1976).

142. Others have attempted to bring a degree of analytic clarity to this area by arguing that one or more of the foregoing concepts are not properly treated as "selfexecution" issues. Thus, the Restatement (Third) of Foreign Relations Law notes that 
With respect to treaties, however, the term has come to be understood in an additional sense. Among the few aspects of the self-execution doctrine about which there appears to be a consensus is that a treaty that is not self-executing is unavailing to the litigant relying on it in court. Perhaps for this reason, the notion has begun to take hold in the lower courts that a treaty that is not self-executing is not the law of the land. ${ }^{143}$ This innovation, in combination with the inherent ambiguity of the term "self-executing" and the indiscriminate use of the term to describe a variety of distinct concepts, has produced what has been correctly described as "the most confounding [doctrine] in treaty law."144

To the extent that a treaty is not the law of the land, the framework proposed below for examining treaty-based claims is entirely inapplica-

the question whether a treaty creates a cause of action is distinct from the question whether a treaty is self-executing. See Restatement (Third) of the Foreign Relations Law of the United States $\S 111 \mathrm{cmt}$. h (1987). But these efforts have failed. The courts continue to address the existence of a cause of action as a "self-execution" issue. See supra note 137. Moreover, as discussed above, the term "self-executing" is used in other contexts to describe laws that do not themselves confer a remedy, so using the term to describe a treaty that does not itself confer a right of action cannot be said to be a misuse of the term. Finally, even if the "cause of action" issue were excluded from the "self-execution" doctrine, the doctrine would still address several other distinct concepts.

I propose instead that we simply recognize that the terms "self-executing" and "non-self-executing" are no more terms of art with respect to treaties than with respect to statutory and constitutional provisions. The statement that a treaty is self-executing is no less ambiguous than the statement that the Takings Clause or the Commerce Clause is self-executing. If used at all, the term should be modified, as it is when used to describe statutory and constitutional provisions. Better yet, the terms should be avoided entirely. Instead, courts and commentators should resolve the various issues involved by addressing them separately and self-consciously. Each of these issues is typically addressed with respect to statutes and constitutional provisions without asking whether they are "self-executing." The issues should henceforth also be addressed with respect to treaties without resort to the term "self-executing" or the doctrine that bears its name. See Koh, supra note 54, at 2383; Myres McDougal, Remarks, 45 Proc. Am. Soc'y Int'l L. 102 (1951) ("This word 'self-executing' is essentially meaningless, and . . the quicker we drop it from our vocabulary the better for clarity and understanding."); Myres McDougal, The lmpact of International Law upon National Law: A PolicyOriented Perspective, 4 S.D. L. Rev. 25, 77 (1959) ("The words self-executing and nonself-executing embrace neither intrinsic nor historic meaning nor magic to resolve the issue."); Jordan Paust, Self-Executing Treaties, 82 Am. J. Int'l L. 760, 783 \& n.132 (1988).

143. See, e.g., United States v. Postal, 589 F.2d 862, 878 (5th Cir.), cert. denied, 444 U.S. 832 (1979); In re Alien Children Educ. Litig., 501 F. Supp. 544, 590 (S.D. Tex. 1980), aff'd on other grounds sub nom. Plyler v. Doe, 457 U.S. 202 (1982). Distinguished commentators have also advanced this interpretation of what it means for a treaty not to be self-executing. See Louis Henkin, Foreign Affairs and the Constitution 157 (1972) [hereinafter Henkin, Foreigu Affairs and the Constitution]; Alona E. Evans, Some Aspects of the Problem of Self-Executing Treaties, 45 Proc. Am. Soc'y lnt'l L. 66, 68 (1951); Henkin, supra note 126, at 532. 
ble, as my proposals are based on the Supremacy Clause's designation of treaties as "law." I do not here examine the circumstances in which the conclusion that a treaty is not the law of the land is warranted or permissible. But I do propose that this issue, like the others now addressed under the self-execution rubric, be addressed separately and self-consciously by the courts rather than through the amorphous selfexecution doctrine. The courts should assess the particular ground being advanced to overcome the Supremacy Clause's designation of "all" treaties of the United States as "Law of the Land." Given the clarity of that text, a conclusion that a particular treaty, valid and in force internationally, is not the "Law of the Land" must be based on exceedingly weighty textual, structural, or historical arguments. ${ }^{145}$

As shown below, the Supreme Court's grounds for declining to apply treaties in particular cases do not distinguish those treaties from statutory or constitutional provisions. To be sure, some of the Court's reasons for not applying the treaties in cases before them are in tension with the treaties' status as "law." But that same tension exists when the courts decline to apply statutory and constitutional provisions for analogous reasons. In the latter contexts, the courts confront the tension and resolve it without concluding that the statutory or constitutional provision at issue is not the "Law of the Land." In the treaty context, the courts have thus far been able to avoid confronting the tension through the facile conclusion that, because the treaty is not selfexecuting, it is not the law of the land. The cavalier treatment this question has received in the treaty context is unacceptable. A treaty may well be unenforceable in the courts in certain circumstances, just as statutes and constitutional provisions sometimes are. That conclusion may well lead a strict Austinian to question the status as "law" of all three. ${ }^{146}$ But, if so, their non-law status would be explained by their

145. There are some categories of treaties whose nonlegal status can be squared with the text of the Supremacy Clause or justified by weighty structural or historical arguments: treaties that purport to accomplish what is beyond the treaty-making power, treaties that infringe individual rights protected by other provisions of the Constitution, or treaties that have been terminated or superseded by a later treaty or by legislation. It is fairly well-accepted that treaties in these categories do not themselves have domestic legal force. See Henkin, Foreign Affairs and the Constitution, supra note 143, at 156-61. But see Lobel, supra note 54, at 1096-1114 (questioning the last-in-time rule).

But the notion that a treaty that is not self-executing is not the law of the land, combined with the oft-repeated statement that a treaty's self-executing character is largely a matter of intent, has led some courts to reach a far more controversial conclusion: that a treaty is the law of the land only if the U.S. treaty-makers affirmatively intended that it be the law of the land. See, e.g., Postal, 589 F.2d at 878 . The Supremacy Clause has been effectively transformed by these courts from a declaration that all treaties are the law of the land into a provision giving the U.S. treaty-makers the power to make treaties the law of the land. Whether there are categories of treaties other than those recognized above that, though valid and in force internationally, are not the law of the land is an issue that 1 leave for another day.

146. Cf. infra note 167 . 
unenforceability in the courts, which would in turn be explained by other factors. To use their supposed non-law status to explain their unenforceability in the courts, as some courts applying the self-execution doctrine appear to be doing, is a very different matter. At any rate, the conclusion that a treaty is unenforceable in the courts should be defended forthrightly and in full cognizance of the intended consequences of the Supremacy Clause's designation of treaties as "supreme Law of the Land," not through some ill-defined and little understood doctrine.

\section{B. Judicially Enforceable Obligations}

A treaty, like a statute or a constitutional provision, is enforceable in the courts only if it establishes judicially enforceable obligations. If it is instead hortatory, a litigant claiming that the defendant has violated the treaty will lose on the merits because the treaty does not in fact require the defendant to behave otherwise than he has been behaving. Even if the treaty contemplates the establishment of obligations affecting the individual, the individual's suit may be dismissed as premature because the treaty does not purport to establish those obligations itself, but instead delegates to the legislature the responsibility of establishing them. Finally, the treaty may establish an obligation, but the obligation may be unenforceable in the courts because it raises political rather than judicial questions.

1. Obligations. - As shown above, the Supremacy Clause was designed to maximize compliance by the United States with its treaty obligations. ${ }^{147}$ By declaring treaties to be the law of the land, the Framers allocated first-line responsibility for treaty enforcement to the courts. The first question that must be addressed in determining whether a treaty may be enforced in the courts should therefore be whether the treaty imposes an obligation on the United States.

Certain treaty provisions might be said to set forth aspirations rather than to impose obligations. Such provisions have sometimes been described as "precatory" or "hortatory." Often the treaty provisions are described as "non-self-executing" for this reason. ${ }^{148}$ Treaty provisions have been held not to be self-executing when they require states to "use their best efforts" to achieve certain goals, ${ }^{149}$ or when they urge the parties to "promot[e] and encourag[e]" certain ends. 150

147. See supra part II.B.

148. INS v. Stevic, 467 U.S. 407,429 n.22 (1984).

149. Id.

150. Sei Fujii v. State, 242 P.2d 617, 619 n.2 (Cal. 1952) (quoting U.N. Charter art. 1). In Sei Fujii, the California Supreme Court held that the provision of the U.N. Charter requiring states to "promot[e] and encourag[e] respect for human rights . . . without distinction as to race, sex, language, or religion" was not self-executing in the sense that it did not, of its own force, nullify state laws making distinctions on such grounds. Id. The decision is best understood as a decision that the Charter was setting forth 
Such provisions might be said to impose "obligations" in a loose sense of the term: the obligation of every party in good faith to make appropriate efforts to achieve the aspirations. But obligations of this nature do not give rise to correlative legal "rights."

Tbe same issue is often addressed by the courts in the statutory and constitutional contexts. For example, to determine whether a federal statute or constitutional provision confers a "right" on a person that can be enforced under section $1983,{ }^{151}$ the Supreme Court held recently that the first question to be addressed is " "whether the provision in question creates obligations binding on the governmental unit or rather does no more than express a congressional preference for certain kinds of treatment.' "152 This is of course very similar to the distinction between treaty provisions that impose obligations and those that are hortatory. ${ }^{153}$ Thus, outside the treaty context, the courts routinely distinguish obligatory legal provisions from hortatory provisions. This aspect of the analysis therefore should not be unfamiliar to the courts. 154

There is one complication with respect to treaties, however. It might be contended that a treaty is hortatory because there is no effective mechanism to enforce it internationally. This argument, if accepted, would render many treaty provisions unenforceable domestically; indeed, the lack of effective enforcement mechanisms has

aspirations rather than obligations. Alternatively, the decision might be understood as resting on justiciability grounds: because the provision leaves the parties with significant discretion in determining how and when best to promote respect for human rights, it is up to the political branches, rather than the courts, to exercise that discretion. See infra notes 180-202 and accompanying text. The question whether the treaty imposes an obligation and the question whether the obligation it imposes is justiciable are obviously closely related.

151. Section 1983 provides:

Every person who, under color of any statute, ordinance, regulation, custom, or usage, of any State or Territory or the District of Columbia, subjects, or causes to be subjected, any citizen of the United States or other person within the jurisdiction thereof to the deprivation of any rights, privileges, or immunities secured by the Constitution and laws, shall be liable to the party injured in an action at law, suit in equity, or other proper proceeding for redress.

42 U.S.C. $\S 1983$ (1981).

152. Dennis v. Higgins, 111 S. Ct. 865, 871 (1991) (quoting Golden State Transit Corp. v. City of Los Angeles, 493 U.S. 103, 106 (1989), which quotes Pennhurst State Sch. \& Hosp. v. Halderman, 451 U.S. 1,19 (1981)).

153. See Pennhurst, 451 U.S. at 24 (Developmentally Disabled Assistance and Bill of Rights Act "intended to be hortatory, not mandatory").

154. The issue in the treaty context is different in one respect: whether the treaty imposes an obligation is not governed by the intent of Congress or even the President and two-thirds of the Senate (the treaty-makers); it is, rather, a matter of treaty interpretation, determined by rules of international law relating to treaty interpretation. See Ware v. Hylton, 3 U.S. (3 Dall.) 199, 236-37 (1796); Foster v. Neilson, 27 U.S. (2 Pet.) 253, 313-14 (1829); see generally Vienna Convention on the Law of Treaties, May 23, 1969, arts. 31-33, 1155 U.N.T.S. 330-331 (rules of treaty interpretation). 
led some to question the status of international law as law ${ }^{155}$ and others to describe international law as a primitive legal system. ${ }^{156}$ But the Framers recognized the limited efficacy of international mechanisms for enforcing treaties, and they nevertheless made treaties enforceable by individuals in our courts. The Supremacy Clause made legally binding treaties that would otherwise have been only morally binding. In determining whether the treaty imposes an obligation on the United States to behave in a given way, therefore, the likelihood that the other party would take steps to secure a sanction for the violation, or that any such steps would prove effective, should play no part in the analysis.

2. Delegation. - What many consider to be the prototype of a non-self-executing treaty may also be understood as a treaty that does not itself establish the obligation that the litigant is seeking to enforce, but its compatibility with the Supremacy Clause is best perceived by comparing it with a statute that delegates law-making power to an administrative agency. This category is typified by the treaty involved in the case that gave birth to the self-execution doctrine, Foster $v$. Neilson. ${ }^{157}$ Foster involved a treaty providing that certain Spanish grants "shall be ratified and confirmed to the persons in possession of the lands."158 The plaintiff claimed title to land in Florida pursuant to Spanish grants. The Court rejected his treaty argument on the ground that the treaty did not itself "ratify or confirm" the Spanish grants, but instead obligated the United States to "ratify and confirm" the grants in the future. The Court compared treaties to contracts and held that this contract was executory-it was a promise to perform a particular act. Such provisions, the Court held, must be executed by the legislature before they may be applied by the courts. ${ }^{159}$ Whether a treaty provision is executory or not was clearly, in the Court's view, a matter of treaty interpretation, and the Court decided the issue by relying on the treaty's language. The provision would not have been executory, in the Court's view, if it had said that the grants were "hereby" confirmed. 160 Indeed, in a later case Chief Justice Marshall concluded that the treaty provision at issue in Foster was not in fact executory. ${ }^{161}$ His about-face on this point resulted from his consultation of the Spanish text, which provided that the grants were to "remain ratified and confirmed."162

155. See Austin, supra note 26, at 187-88.

156. See Kelsen, supra note 45 , at 16 (asserting that the prevalence of "self help" in the absence of a "centralized coercive order" is the mark of a "primitive legal order").

157. 27 U.S. (2 Pet.) 253 (1829); see People of Saipan v. United States Dep't of Interior, 502 F.2d 90, 101 (9th Cir. 1974), cert. denied, 420 U.S. 1003 (1975); Goldwater v. Carter, 481 F. Supp. 949,962 n.59 (D.D.C.), rev'd on other grounds, 617 F.2d 697 (D.C. Cir.) (en banc), vacated, 444 U.S. 996 (1979).

158. 27 U.S. (2 Pet.) at 310.

159. See id. at 314 .

160. Id.

161. See United States v. Percheman, 32 U.S. (7 Pet.) 51, 88 (1833).

162. Id. 
This language showed that the treaty did not, as he had previously concluded, "stipulat[e] for some future legislative act."163

The Court in Foster thus decided that the treaty did not itself establish the obligation that the litigant relying on it was seeking to enforce-the obligation to recognize Spanish grants as ratified and confirmed-but instead imposed a different obligation on the United States-the obligation to enact legislation to ratify and confirm the grants. That the former obligation may not be enforced in court before Congress fulfills the latter obligation does not distinguish this category of non-self-executing treaty from statutes that might similarly be described as non-self-executing. If Congress were to enact a statute instructing an administrative agency to adopt regulations for the benefit of a particular class of individuals, and an individual in that class were to bring suit before the adoption of the regulation claiming the benefit contemplated hy the law, the litigant's suit would be dismissed as premature. ${ }^{164}$ The Foster category of non-self-executing treaty can be conceived as a delegation of law-making responsibility by treaty to Congress. The distinction is between a treaty obligation to behave in given ways towards the individual and a treaty obligation to enact a law requiring that individuals be treated in a given way. The latter obligation would not be violated if executive officials treated the individuals in the disapproved way; it would only be violated if the legislature failed to enact the required law. ${ }^{165}$ Thus, an individual claiming that his treaty rights have been infringed by the treatment he received would lose because the rights were not infringed, not because the treaty lacks the force of domestic law. ${ }^{166}$ It is a law that by its terms is addressed to Congress. ${ }^{167}$

163. 1d. at 89 .

164. If the litigant were to bring suit against the agency seeking to require it to initiate proceedings for adopting the regulation, the suit would be permitted under certain circumstances. See Richard B. Stewart \& Cass R. Sunstein, Public Programs and Private Rights, 95 Harv. L. Rev. 1193, 1205-06, 1267-89 (1982) (discussing "right of initiation"). An analogous claim against Congress seeking to force it to implement a treaty would face insuperable justiciability problems, however.

165. See D'Amato, supra note 54, at 98-99.

166. That an agency's exercise of law-making authority validly delegated to it by Congress is not reviewable by the courts is compatible with the courts' duty to say what the law is. To the extent the agency has been delegated law-making authority, the law is whatever the agency says it is. See Henry P. Monaghan, Marbury and the Administrative State, 83 Colum. L. Rev. 1, 25-26 (1983) [hereinafter Monaghan, Marbury and the Administrative State]. The courts can of course review the agency's regulation to determine whether it is within the scope of the delegation. Because treaties and statutes are considered to be of equivalent stature, the courts may not similarly review a statute to determine whether it is consistent with the treaty. That is because, as a result of the last-in-time rule, the statute supersedes the treaty (at least if Congress's power to legislate on the subject is not based on the treaty).

167. Because there is no sanction for Congress' violation of the obligation, see supra notes 164,166 , a strict Austinian would deny that the treaty is law. Whatever the merits of such a position, it is a conclusion based on the fact that the treaty is 
Recognizing a category of treaty that is unenforceable in the courts because the obligation it imposes is an obligation to enact legislation is relatively unproblematic. ${ }^{168}$ Identifying such treaties, however, is another matter. The easiest case is when the treaty expressly states that the United States' obligation is contingent on the enactment of legislation. ${ }^{169}$ At the other end of the spectrum, it is clear that a treaty prohibiting conduct by the United States towards individuals does not require legislative implementation to be enforceable by individuals in the courts. ${ }^{170}$ In between, determining whether the treaty obligation is an obligation to enact legislation is tricky in light of the facts that (a) in some states (most states, according to Justice Iredelli ${ }^{17}$ ) treaties always require implementing legislation, and (b) the Supremacy Clause was designed to establish a different rule in the United States. The Foster Court focused on whether the treaty obligated the United States to "perform a particular act" or, on the other hand, purported to "act directly on the subject." 172 But, as we saw above, in Great Britain, even a treaty providing that tariffs are "hereby" set at a given level requires

unenforceable in the courts, which is in turn based on historical and structural considerations (such as the last-in-time rule) of the type that I argued above, see supra text accompanying note 145 , were required to justify such a conclusion. The unenforceability of the treaty is not explained by its non-law status; rather, its non-law status results from its unenforceability, which is in turn explained by other factors. Thus, while the statement that a non-self-executing treaty is not the law of the land, as applied to this category of treaty, may be true as a descriptive matter, the statement lacks prescriptive value. It is epiphenomenal.

168. This category of non-self-executing treaty is relatively unproblematic because it does not create a discrepancy between our international treaty obligation and our domestic law. Rather, it recognizes that the international obligation is an obligation to enact legislation, an obligation that is not judicially enforceable for separation-of-powers reasons. See supra notes $164,166-167$. 1t would be far more problematic to recoguize (as the Postal court appears to have held, see supra note 145) that a treaty itself imposes an international obligation on the United States to behave in a given way towards individuals, but that it is not enforceable in the courts by individuals because it does not have the force of domestic law.

169. See United States v. American Sugar Refining Co., 202 U.S. 563, 576 (1906), involving a treaty providing specifically that the United States' obligations did not arise until the enactment of legislation by Congress.

170. See, e.g., Commonwealth v. Hawes, $76 \mathrm{Ky}$. (13 Bush) 697, 702-03 (1878):

When it is provided by treaty that certain acts shall not be done, or that certain limitations or restrictions shall not be disregarded or exceeded by the contracting parties, the compact does not need to be supplemented by legislative or executive action, to authorize the courts of justice to decline to override those limitations or to exceed the prescribed restrictions, for the palpable and all-sufficient reason, that to do so would be not only to violate the public faith, but to transgress the "supreme law of the land."

This opinion has been characterized as "very able" by the Supreme Court. See United States v. Rauscher, 119 U.S. 407, 427-28 (1886); see also Restatement (Third) of the Foreign Relations Law of the United States $\$ 111$ reporter's note 5 (1987).

171. See supra notes $116-117$.

172. Foster v. Neilson, 27 U.S. (2 Pet.) 253, 314 (1829). 
an act of legislation to give it the force of domestic law. ${ }^{173}$ The Court held in Ware, ${ }^{174}$ and Chief Justice Marshall agreed in Foster, ${ }^{175}$ that the Supremacy Clause established a different rule in the United States. That different rule might have been that no legislation is required in the United States even if the treaty purports to require legislation. Marshall declined to go that far. He held that legislation was required if the parties to the treaty affirmatively "stipulat[e] for some future legislative act."176 That holding is unexceptionable, but there is a degree of circularity in inferring such a stipulation from language in a treaty that appears to contemplate the performance of a particular act. ${ }^{177}$

Marshall apparently regarded the treaty involved in Foster as one that, by affirmative agreement of the parties, required an act of legislation. The pitfalls of inferring such an agreement from ambiguous evidence are vividly illustrated by Marshall's about-face, in United States $v$. Percheman, with respect to the very same treaty provision. ${ }^{178}$ A discussion of the types of evidence that might appropriately support a conclusion that a treaty "stipulates for some future legislative act" is beyond the scope of this Article. ${ }^{179}$ For present purposes, it is sufficient to note that this category of treaties represents a determination that the treaty does not itself purport to establish the obligation that the litigant relying on it seeks to enforce, but instead obligates the United States to enact legislation that would in turn affect the individual in some way.

3. Justiciability. - The self-execution problem is of course at bottom a separation-of-powers problem. The desiguation of a rule as "law" in a given state serves to assign responsibilities among officials of

173. See supra text accompanying notes $114-116$.

174. See supra note 117 and accompanying text.

175. See supra text accompanying note 125 .

176. United States v. Percheman, 32 U.S. (7 Pet.) at 89.

177. Marshall's focus on whether the language of the provision appeared to contemplate a particular act overlooked the possibility that the parties chose the language not because they affirmatively intended to require a legislative act, but because the domestic law of one or more of the parties required the performance of a particular act regardless of the parties' intent. As Justice Iredell recoguized in Ware, at that time most nations followed the British rule. See Ware v. Hylton, 3 U.S. (3 Dall.) 199, 262, 270 (1796).

I78. 32 U.S. at 51.

I79. Some courts have recently held that the existence in a multilateral treaty of a provision requiring all parties to inform the other parties, or a central depository, of any legislation they may enact to give effect to the treaty's provisions means that the treaty as a whole is not self-executing. See, e.g., Tel-Oren v. Libyan Arab Republic, 726 F.2d 774, 809 (D.C. Cir. I984), cert. denied, 470 U.S. 1003 (1985); Haitian Refugee Ctr. v. Gracey, 600 F. Supp. 1396, 1406 (D.D.C. 1985), aff'd on other grounds, 809 F.2d 794 (D.C. Cir. 1987). Such a provision, however, may simply reflect the fact that, in certain states, treaties never have domestic effect without implementing legislation. Additionally, the provision may reflect the fact that some provisions of the treaty require legislation, while others do not. It is well settled that some provisions of a treaty may be self-executing while others are not. See Restatement (Third) of the Foreign Relations Law of the United States § $111 \mathrm{cmt}$. h (1986). 
the state for enforcing the rule. In Great Britain and the United States, the courts are responsible for enforcing laws in adjudicatory contexts. In Great Britain, treaties are not considered law domestically because they are made by the Executive, and the Parliament has exclusive lawmaking authority. ${ }^{180}$ In the United States, the designation of treaties as "law" was intended to make them enforceable directly by courts without the need for legislation. The Supremacy Clause, therefore, addresses the separation-of-powers issue that the self-execution doctrine raises. The doctrine under which treaties require legislative implementation before they may be applied by the courts is in tension with the power-allocating function of the Supremacy Clause. We do not resolve this tension by denominating it a separation-of-powers problem.

But it is helpful to recognize that the same tension arises when courts decline to adjudicate a constitutional claim on political-question grounds. Commentators have pointed out the fundamental inconsistency between the political-question doctrine and the notion that "it is emphatically the province and duty of the judicial department to say what the law is." 181 With respect to the Constitution, as with respect to treaties, there is thought to be a basic tension between their status as law and the inability or incapacity of the courts to give them effect in certain circumstances. The conceptual problem is the same. It should be addressed in a similar manner. ${ }^{182}$

Though the Framers understood that "laws" would generally be enforceable by the courts, they also intended to confine the power of the judiciary to cases of a judicial nature. At the Convention, Madison

doubted whether it was not going too far to extend the jurisdiction of the Court generally to cases arising Under the Constitution, \& whether it ought not to be limited to cases of a Judiciary Nature. . . . The right of expounding the Constitution in cases not of this nature ought not to be given to that Department. ${ }^{183}$

The jurisdiction of the federal courts was nevertheless extended to cases arising under the Constitution without expressly limiting it to cases of a "judiciary" nature because it was "generally supposed that the jurisdiction given was constructively limited to cases of a Judiciary

180. See 1 Hersch Lauterpacht, International Law 226 (1970).

181. Marbury v. Madison, 5 U.S. (1 Cranch) 137, 177 (1803); accord Michael J. Glennon, Constitutional Diplomacy 316 (1990); Henkin, supra note 141, at 600-01; Fritz W. Scharpf, Judicial Review and the Political Question: A Functional Analysis, 75 Yale L.J. 517, 517-19 (1966); Herbert Wechsler, Toward Neutral Principles of Constitutional Law, 73 Harv. L. Rev. 1, 7-8 (1959).

182. Commentators have argued that the "self-execution" doctrine is essentially a version of the political-question doctrine. See, e.g., Charles W. Stotter, Comment, SelfExecuting Treaties and the Human Rights Provisions of the United Nations Charter: A Separation of Powers Problem, 25 Buff. L. Rev. 773, 774 (1976); Quincy Wright, National Courts and Human Rights-The Fujii Case, 45 Am. J. Int'l L. 62, 64 (1951).

183. 2 Farrand, supra note 65 , at 430 . 
nature."184 The justiciability doctrines of standing, mootness, and ripeness, which tell us "who" may invoke the judicial power and "when," 185 are all thought to flow from this limitation, which is thought to be implied in the "case or controversy" requirement. ${ }^{186}$

The political-question doctrine asks "whether" a particular dispute may be resolved judicially, regardless of the concreteness of the dispute or the adversarial relationship of the parties. The answer may be negative either because (a) the nature of the issue renders it inappropriate for judicial resolution or (b) resolution of the dispute has been assigned by the Constitution to a different branch of government. ${ }^{187}$

The first category consists of issues that are thought to require judgments of a political rather than legal nature. Although few today would maintain that there is a bright line between legislation and adjudication, ${ }^{188}$ this version of the political-question doctrine may reflect deeply held intuitions that certain types of issues are inherently not for judicial resolution. Many of the "self-execution" decisions might be understood as applications of this category of the political-question doctrine. In the latter context, the courts ask whether there are "judicially discoverable and manageable standards," 189 while in the former the courts ask whether the treaty provision is "too vagne for judicial enforcement" 190 or "provide[s] specific standards." 191 This category is characterized, however, by legal provisions that leave the political branches with discretion that is sufficiently unguided that the courts consider it inappropriate to intervene. Professor Henkin argnes that

184. Id.

185. Monaghan, Constitutional Adjudication, supra note 106.

186. See, e.g., Allen v. Wright, 468 U.S. 737, 752 (1984).

187. Other considerations have at times been considered relevant, see Baker v. Carr, 369 U.S. 186, 217 (1962) (listing "elements which identify" political questions), but the two noted in the text appear to be the operative ones. See Japan Whaling Ass'n v. American Cetacean Soc'y, 478 U.S. 221, 229-30 (1986) (dismissing "embarrassment from multifarious pronouncements by various departments" as a concern, saying that "we cannot shirk [our] responsibility merely because our decision may have significant political overtones") (quoting Baker v. Carr, 369 U.S. at 217).

188. Cf. Paul M. Bator, The Constitution as Architecture: Legislative and Administrative Courts Under Article 1II, 65 lnd. L.J. 233, 264 (1990) (there are no "rigid and impermeable walls" between the executive and judicial functions). But $\mathrm{cf}$. I.N.S. v. Chadha, 462 U.S. 919, 951 (1983) ("The Constitution sought to divide the delegated powers of the new Federal Government into three defined categories, Legislative, Executive, and Judicial, to assure ... that each branch of government would confine itself to its assigned responsibility.").

189. Baker v. Carr, 369 U.S. at 217. The courts similarly ask, in determining whether an individual has a "right" for the purposes of section 1983, whether the plaintiff's interest is " 'too vague and amorphous' to be 'beyond the competence of the judiciary to enforce." " Dennis v. Higgins, 111 S. Ct. 865, 871 (1991) (quoting Golden State Transit Corp. v. City of Los Angeles, 493 U.S. 103, 106 (1989)).

190. People of Saipan v. United States Dep't of Interior, 502 F.2d 90, 99 (9th Cir. 1974).

191. Diggs v. Richardson, 555 F.2d 848, 851 (D.C. Cir. 1976). 
these are not justiciability decisions at all, but rather determinations on the merits that the conduct being challenged is within the defendant's discretion to perform. ${ }^{192}$ In any event, this category does not include cases in which the obligation imposed by the legal provision is clearcut, such as the obligation not to abduct persons from the territory of another state. The Supreme Court has repeatedly said that the political-question doctrine "is one of 'political questions,' not one of 'political cases." "193

The second category consists of issues the decision of which has been allocated by the Constitution to another branch of government. ${ }^{194}$ It differs from the first category in that it is not necessarily limited to situations in which the commitment of the issue to another branch is inferred from the need to make judgments of a political nature. But there are few constitutional commitments of issues to other branches, and they have been interpreted narrowly by the Court. ${ }^{195}$ It cannot be said that the Constitution allocates decision of treaty issues generally to branches other than the judiciary. ${ }^{196}$ The Supremacy Clause's text and history show that the Framers intended that the courts be the principal enforcers of treaties.

It might perhaps be argued the Constitution allocates to the courts the power to enforce treaties against the states and private individuals, but not against the other branches of the federal government or in the face of inconsistent acts of those branches. We have already seen that the courts may not enforce treaties in the face of subsequent acts of the other branches that take the form of legislation or treaty. ${ }^{197}$ Recoguizing that the courts lack the power to enforce a treaty in the face of an inconsistent unilateral act of the President, however, would be highly problematic in light of the status of treaties as law and the President's constitutional duty to take care that the laws are faithfully executed. ${ }^{198}$ Nevertheless, the President is acknowledged to have limited independ-

192. See Henkin, supra note 141 , at 606 .

193. Baker v. Carr, 369 U.S. at 217.

194. Professor Wechsler considers this the only defensible category of political questions. See Wechsler, supra note 181 , at 7-8.

195. See, e.g., Powell v. McCormack, 395 U.S. 486, 518-48 (1969), in which the apparent textual commitment in Article 1, Section 5 of the Constitution-which provides that "[e]ach House shall be the Judge of the ... Qualifications of its own Members"was interpreted to bar judicial review only of those qualifications expressly set forth in the Constitution. That interpretation bars judicial review of issues that require no policy choices and are among those best suited for judicial resolution, such as whether the Member is at least 25 years old and has been a citizen for at least seven years.

196. See Japan Whaling Ass'n v. American Cetacean Soc'y, 478 U.S. 221, 230 (1986) ("[T]he courts have the authority to construe treaties ....").

197. It is noteworthy that the decisions first articulating the last-in-time rule relied on a political-question rationale. See Whitney v. Robertson, 124 U.S. 190, 195 (1888); The Cherokee Tobacco, 78 U.S. (11 Wall.) 616, 620-21 (1870); Taylor v. Morton, 23 F. Cas. 784, 786-87 (C.C.D. Mass. 1855) (No. 13,799).

198. But cf. Allen v. Wright, 468 U.S. 737, 761 (1983) (relying on the Take Care 
ent legislative authority in the area of foreign affairs that enables him to terminate treaties unilaterally in certain circumstances. ${ }^{199}$ To the extent the President possesses such a power it might be argued that he possesses a corresponding power to determine that compliance with a treaty is no longer in the national interest in particular circumstances without terminating the treaty. I do not examine this issue further here. But I note that, whatever the President's freedom from judicial control in this regard, it is not necessarily shared by lower level executive officials. ${ }^{200}$

The two categories of "non-self-executing" treaties discussed above correspond roughly to the two categories of political questions. "Hortatory" treaty provisions may be conceived not as provisions that do not impose obligations, but as provisions that impose obligations that leave much to the discretion of the parties; the unenforceability of such obligations in the courts may thus be ultimately grounded on the absence of judicially manageable standards. And "executory" treaty provisions may be analogized to treaties that themselves delegate firstline enforcement responsibility to the legislature. Moreover, the two categories may significantly overlap. For example, the reason for requiring legislation to implement "executory" treaty provisions might in many cases be a conviction that, when a treaty consists of mutual promises, determining the time and manner of the United States' performance in relation to that of other parties requires the exercise of discretion and gamesmanship that is beyond the competence or proper role of the judiciary because it turns on judicially unmanageable standards.

In the constitutional context, too, the courts have tended to blur the two categories of political questions, often treating them as one. ${ }^{201}$

Clause to support its conclusion that the President's determination how to execute a particular law was not subject to judicial review).

199. See Goldwater v. Carter, 444 U.S. 996, 1006-07 (1974) (Brennan, J., dissenting).

200. The Court has on numerous occasions enforced treaties against executive officials. See, e.g., United States v. Rauscher, 119 U.S. 407 (1886) (limiting federal criminal prosecution to charge by which respondent was extradited); Chew Heong v. United States, 112 U.S. 536 (1884) (enforcing treaty against executive officials); United States v. Brooks, 51 U.S. (10 How.) 442, 460 (1850) (affirming right to disputed land "against the claim of the United States"); see also Perkins v. Elg, 307 U.S. 325 (1939) (rejecting executive's construction of treaty).

201. See Japan Whaling Ass'n v. American Cetacean Soc'y, 478 U.S. 221, 230 (1986):

The political question doctrine excludes from judicial review those controversies which revolve around policy choices and value determinations constitutionally committed for resolution to the halls of Congress or the confines of the Executive Branch. The Judiciary is particularly ill suited to make such decisions, as "courts are fundamentally underequipped to formulate national policies or develop standards for matters not legal in nature."

(quoting United States ex rel. Joseph v. Cannon, 642 F.2d 1373, 1379 (1981)). 
Thus, with respect to both treaties and the Constitution, whether the responsibility for enforcing a particular provision has been entrusted to a branch other than the judiciary may in the end turn on whether enforcement of the provision involves the application of judicially unmanageable standards. And an affirmative answer to that question may, as Professor Henkin argues, mean simply that the relevant branch has the discretion to behave as it has been behaving-i.e., that, on the merits, the law does not impose an obligation to behave differently. ${ }^{202} 1 \mathrm{do}$ not here advocate any particular version of the political-question doctrine, nor do 1 contend that it provides an independent ground for refusing to enforce treaties that do not fit into the first two categories of unenforceable treaty provisions discussed above. But 1 do propose that the parallels between the political-question doctrine and the doctrine of self-executing treaties be recoguized and that the tension between the latter doctrine and the status of treaties as "law" be resolved, as it generally is with respect to constitutional provisions, not by denying the provision's status as law, but by determining whether there are overriding reasons to hold that what is prima facie a "law" is nevertheless unenforceable in the courts.

\section{Correlative Rights}

lt is often said that an individual may enforce a treaty in our courts only if the treaty confers rights on the individual. For that statement to have any prescriptive value, the term "rights" cannot be understood in the sense of secondary rights, under either international or domestic law. As we have seen, the Framers recognized that individuals do not have secondary rights under treaties as a matter of international law, but they intended nevertheless that treaties be enforceable by individuals domestically. ${ }^{203}$ Moreover, the statement purports to tell us when an individual has domestic secondary rights under a treaty. If the term "rights" were understood in the sense of domestic secondary rights, the statement would be a tautology.

The statement would be consistent with both the Framers' intent and the Supreme Court's decisions if we understood the term in its sense of primary right. If we so understood the term, the existence of a

202. Professor Henkin argues that the Supreme Court's "political question" decisions represent determinations either that the defendant was acting within the scope of its constitutional authority or that the requested equitable relief was properly denied as a matter of equitable discretion. Henkin, supra note 141, at 606; cf. United States Dep't of Commerce v. Montana, 60 U.S.L.W. 4279, 4284 (Mar. 31, 1992) ("In invoking the political question doctrine, a court acknowledges the possibility that a constitutional provision may not be judicially enforceable. Such a decision is of course very different from determining that specific congressional action does not violate the Constitution. That determination is a decision on the merits that reflects the exercise of judicial review, rather than the abstention from judicial review that would be appropriate in the case of a true political question." (citations omitted)).

203. See supra part 11. 
right would be governed by the legal rules that are employed to determine when individuals have standing to enforce statutory and constitutional provisions that impose obligations on government officials. Employing these legal rules with respect to treaties is, moreover, consistent with the Supremacy Clause's equivalent treatment of constitutional, statutory, and treaty law. Finally, the relevant standing rules are well suited to application in the treaty context.

The supremacy clause invalidates governmental action that violates a treaty. ${ }^{204}$ Because government deprivations of liberty or property must ordinarily be preceded or followed by a hearing, an individual who has a primary right under a treaty-that is, standing to enforce itwill ordinarily have an opportunity to enforce the treaty defensively in an adjudicatory setting. The sanction of nullity should satisfy a strict sanctionist that the treaty is genuinely law. But, as to treaty violations already committed, the defensive sanction leaves a substantial gap between the primary right and the secondary right. This gap is significantly narrowed by rights of action afforded by the common law, state and federal, and by federal statutes authorizing remedies for violations of federal law.

Only where a treaty confers primary rights but neither a statute nor the common law supplies a right of action should it be necessary to locate a right of action in the treaty itself. If the treaty does not confer a right of action expressly, it will be necessary to determine whether a right of action is implicit in the treaty. This Article proposes that a right of action be deemed to be implicit in a treaty if failure to afford it would give rise to, or exacerbate, the responsibility of the United States to the state of the litigant's nationality under international law. The same analysis should be employed to determine what the appropriate remedy is when a treaty is relied upon defensively or when a right of action is afforded by a statute that does not specify the remedy.

1. Standing and Primary Rights. - When an individual seeks to enforce a constitutional or statutory provision that imposes a duty on the state, the courts usually consider as a threshold question whether the individual has standing. ${ }^{205}$ A showing of standing is of course required

204. Unless, of course, the actors have the constitutional power to violate or supersede treaties or have been instructed to violate the treaty by someone having such power. See supra text accompanying notes 197-220.

205. Although the courts often address standing as a threshold issue, there is no reason that the non-constitutional aspects of standing have to be considered before other legal issues, such as whether the litigant is entitled to a remedy. The conclusion that an individual is entitled to a remedy is necessarily a conclusion that the individual has standing to obtain the remedy. See infra text accompanying note 247 . Thus, the court could bypass the standing issue by turning directly to the remedy issue. Under the analysis proposed helow, a litigant should be entitled to a remedy if affording the individual a remedy would prevent or cure a violation of international law by the United States to the state of the individual's nationality. See infra text accompanying notes 316-325. If rules of customary international law concerning exhaustion of local 
when the individual seeks to enforce a duty of the state based on a treaty. But, though the courts often address standing in treaty cases, they appear to consider the issue to be distinct from the question whether the individual has a "right" under the treaty such that the treaty may be said to be self-executing. ${ }^{206}$ The two inquiries in fact address the same issue and should be collapsed.

The doctrine of standing is a relatively recent creation. Its emergence as a separate doctrine is attributable to the growth of the administrative state. ${ }^{207}$ Because the Supreme Court decisions suggesting that a treaty may be enforced by individuals only if it confers a right on the individual predate this development, it is not surprising that these decisions do not connect the issues of primary rights and standing. Today, the connection should be plain: like statutes imposing duties on administrative agencies, treaties by their nature impose duties on the state. Standing doctrine, which identifies who may enforce statutes that impose duties on government agencies, addresses precisely the same question as this branch of the "self-execution" question: does the litigant have a correlative primary right?

Because treaties are laws that impose duties on the state, the standing decisions relating to two federal statutes are particularly pertinent. Section 1983 authorizes actions against state officials by individuals who have been deprived of "any rights, privileges, or immunities secured by the Constitution and laws" of the United States. ${ }^{208}$ The Supreme Court's decisions regarding when an individual has a "right" under the Constitution or federal laws for purposes of section 1983 thus not only address the precise question posed by the "primary right" inquiry, but also employ the same terminology. Indeed, Professor Monaghan has recently described the requirement of a "right" under section 1983 to be a requirement of a "primary right" as Hart and Sacks define the term. ${ }^{209}$ The Supreme Court has recently held that three considerations determine whether an individual has a "right" under section 1983:

In deciding whether a federal right has been violated, we have considered [1] whether the provision in question creates obligations binding on the governmental unit or rather "does no

remedies were adopted for the purpose of determining the individual's entitlement to a remedy in our domestic courts, as suggested infra notes 319-325 and accompanying text, such rules would also provide a floor for standing. If the standing issue is addressed first, the international-law rules discussed below should be consulted on this issue; standing should not be denied to an individual who is entitled to a remedy under those rules.

206. See, e.g., United States v. Verdugo-Urquídez, 939 F.2d 1341, 1355-58 (9th Cir. 199I). (1988).

207. See William A. Fletcher, The Structure of Standing, 98 Yale L.J. 221, 225 
more than express a congressional preference for certain kinds of treatment." [2] The interest of the plaintiff must not be "too vague and amorphous" to be "beyond the competence of the judiciary to enforce." [3] We have also asked whether the provision in question was "inten[ded] to benefit" the putative plaintiff. 210

The standing part of that test is the third consideration-whether the provision was "intended to benefit" the plaintiff.211

This requirement is similar to the standing requirements under the Administrative Procedure Act, which provides that a "person suffering legal wrong . . . or adversely affected or aggrieved by agency action within the meaning of a relevant statute, is entitled to judicial review thereof."212 A person is "adversely affected or aggrieved" by agency action, according to the Supreme Court, if "the injury he complains of (his aggrievement, or the adverse effect upon him) falls within the 'zone of interests' sought to be protected by the statutory provision whose violation forms the legal basis for his complaint."213 Professor Monaghan has written that the standing requirements under these two statutes appear to be converging, and that both turn on a distinction between "direct" and "incidental" beneficiaries. ${ }^{214}$

This distinction is peculiarly suited to application in the treaty context. The distinction between direct and incidental beneficiaries is reminiscent of the distinction applied in contract law to determine the circumstances in which someone who is not a party to a contract may enforce a contractual obligation as a third-party beneficiary. Treaties are contracts between nations, ${ }^{215}$ and the position of individuals with respect to treaties has been compared to that of a third-party beneficiary under a private contract. ${ }^{216}$ Indeed, in defining the concept of a "primary right," Hart and Sacks give the third-party beneficiary situation as an example. ${ }^{217}$

210. Golden State Transit Corp. v. City of Los Angeles, 493 U.S. 103, 106 (1989) (citations omitted) (quoting Pennhurst State Sch. \& Hosp. v. Halderman, 451 U.S. 1, 19 (1981) and Wright v. Roanoke Redev. \& Hous. Auth., 479 U.S. 418, 430, 431-33 (1987)). The Court quoted this same language in Dennis v. Higgins, 111 S. Ct. 865, 871 (1991).

211. The first consideration listed by the Court addresses whether the treaty imposes an obligation or is instead precatory, and the second relates to the justiciability of the obligation. See supra notes 152,189 and accompanying text.

212. 5 U.S.C. $\$ 702$ (1988).

213. Lujan v. National Wildlife Fed'n, 110 S. Ct. 3177,3186 (1990).

214. Monaghan, supra note 26 , at 257-60.

215. See Foster v. Neilson, 27 U.S. (2 Pet.) 253, 314 (1829); supra note 1.

216. See, e.g., Lea Brilmayer, International Law in American Courts: A Modest Proposal, 100 Yale L.J. 2277, 2304 (1991).

217.

If $A$ promises $B$ that he will pay $B$ 's debt to $C$ and the promise is valid and binding, it is obvious that $C$ has a primary "right" at least in the sense of a claim to the benefit of the performance of $A^{\prime}$ 's promise. But as every first-year law 
Adopting the rules applied by the courts to determine whether individuals have standing to enforce statutes or constitutional provisions that are in terms addressed to the government will hardly eliminate all of the problems that courts have encountered in determining when an individual may enforce a treaty. Indeed, standing doctrine is regularly the subject of ridicule and pleas for abandonment. ${ }^{218}$ The point here, though, is that once it has been determined that a treaty provision imposes an obligation on the state, the standing inquiry and the "primary right" inquiry are the same: is this individual within the class of persons who should be permitted to enforce the obligation in court? Despite the disarray in which we find standing law, collapsing the standing and primary right inquiries would simplify the treaty-application process by replacing two sets of rules with one. If nothing else, standing doctrine is far more familiar to the courts than treaty application doctrine.

In fact, standing doctrine would add considerable predictability and coherence to the treaty application process. The problematic standing cases in the statutory and constitutional contexts involve challenges to agency action having broad and diffuse impacts affecting a wide array of persons in varying ways (thus giving rise to multipolar disputes), or injuries that are either abstract or indirectly or remotely traceable to the agency's action. ${ }^{219}$ If a suit is brought to challenge agency action of this type as a violation of the treaty, ${ }^{220}$ the standing

student knows it has not been obvious to many courts that $C$ has a right of action against $A$ if $A$ fails to pay the debt.

.Hart \& Sacks, supra note 26, at 152. The Supreme Court's decisions concerning implication of rights of action from statutes also support the proposition that an intended beneficiary of a law has a primary right under it. In Cort v. Ash, 422 U.S. 66 (1975), the Court listed as the first of four factors relevant to the issue whether the plaintiff was " 'one of the class for whose especial benefit the statute was enacted,'-that is, does the statute create a federal right in favor of the plaintiff?" Id. at 78 (citation omitted) (quoting Texas \& Pac. Ry. Co. v. Rigsby, 241 U.S. 33, 39 (1916)). Since the court listed this as a factor in determining whether the litigant had a right of action, it must have meant to refer to a primary right. An "especial" beneficiary-like an intended beneficiary-would thus be the holder of a primary right. Similarly, Professor Fletcher has compared the standing inquiry to the question of whether a third-party beneficiary may enforce a contract. See Fletcher, supra note 207, at 238.

218. See, e.g., Lee A. Albert, Standing to Challenge Administrative Action: An lnadequate Surrogate for Claims for Relief, 83 Yale L.J. 425, 442-50 (1974); David P. Currie, Misunderstanding Standing, 1981 Sup. Ct. Rev. 41; Gene R. Nichol, Jr., Abusing Standing: A Comment on Allen v. Wright, 133 U. Pa. L. Rev. 635, 651-59 (1985); Mark V. Tushnet, The New Law of Standing: A Plea for Abandonment, 62 Cornell L. Rev. 663,663 (1977) (criticizing standing doctrine as irrational and concealing "decisions on the merits of the underlying constitutional claim").

219. See, e.g., Allen v. Wright, 468 U.S. 737, 752-53 (1984) (standards for conferring tax exempt status on racially discriminatory schools); Duke Power Co. v. Carolina Envtl. Study Group Inc., 438 U.S. 59, 72-73 (1978) (threat that injuries from nuclear power accident would be inadequately compensated due to limited liability of Price-Anderson Act).

220. See, e.g., Japan Whaling Ass'n v. American Cetacean Soc'y, 478 U.S. 221, 230 
issue may well be difficult to resolve, as it sometimes is with respect to statutes and constitutional provisions. ${ }^{221}$ But, in treaty cases, standing issues have seemed problematic even in the bipolar, "private right" cases that have never generated controversial standing problems in the statutory and constitutional contexts. ${ }^{222}$ The standing problems in these cases can be traced to the understanding that treaties, as instruments of international law, do not confer rights on private individuals. But the Framers changed that (or made it irrelevant), for domestic purposes, when they gave treaties the same legal status as the Constitution and federal statutes. Applying standing doctrine as it is applied in the statutory and constitutional contexts should obviate these problems. In those contexts, it has long been clear that anyone whose liberty or property is protected from governmental interference by law has standing to challenge government conduct depriving him of such liberty or property. ${ }^{223}$

The Ninth Circuit's decision in United States v. Verdugo-Urquidez ${ }^{224}$ illustrates the problems that would be obviated by applying ordinary standing doctrine in treaty cases. Having concluded that the extradition treaty between the United States and Mexico prohibited the United States from unilaterally abducting individuals from Mexican territory, the court struggled to determine whether an individual abducted by the United States from Mexico had standing to invoke the rule in our courts. $^{225}$ If the prohibition had had its source in a statute, there would have been no standing problem. Someone abducted by the government in violation of a law prohibiting his abduction has standing to invoke the prohibition in court. ${ }^{226}$ The action directly affects his lib-

n.4 (1986). The plaintiff in Japan Whaling was seeking to enforce a statute that was alleged to incorporate a standard set forth in a treaty.

221. See, e.g., Haitian Refugee Ctr. v. Gracey, 809 F.2d 794 (D.C. Cir. 1987).

222. On the traditional "private rights" view of standing, see Albert, supra note 218, at 430-42; Monaghan, Constitutional Adjudication, supra note 106, at 1365-68; Stewart \& Sunstein, supra note 164, at 1202-04; Cass R. Sunstein, Standing and the Privatization of Public Law, 88 Colum. L. Rev. 1432, 1434-40 (1988). Some commentators have argued that tbis grudging view of standing was created judicially to restrict the ability of courts in the Lochner era from interfering with social welfare legislation, see Sunstein, supra, at 1435-38; Steven Winter, The Metaphor of Standing and the Problem of Self-Governance, 40 Stan. L. Rev. 1371, 1454-57 (1988), and have denied that the Framers contemplated any such restriction on the judicial power, see Raoul Berger, Standing to Sue in Public Actions: Is It a Constitutional Requirement?, 78 Yale L.J. 816, 817-19 (1969).

223. See, e.g., Sunstein, supra note 222, at 1434-35.

224. 939 F.2d 1341 (9th Cir. 1991).

225. The court examined this question as a "standing" question rather than a "selfexecution" question. Other courts, however, have tackled similar issues as "selfexecution" issues. See supra notes 4,136 . The Ninth Circuit in Verdugo discussed the self-execution issue separately, apparently believing that the issue involved something distinct from standing or the defendant's "rights" under the treaty. See id. at 1349-51.

226. The question of remedy is distinct (if not totally unrelated), and the Ninth Circuit addressed it separately. In the domestic context, the Supreme Court has held, in 
erty, and the statute flatly prohibits the government from depriving him of that liberty. ${ }^{227}$

The individual's standing is not called into question by the fact that the category of persons the treaty seeks to protect is broad. The class of intended beneficiaries will typically be large when the obligation imposed by a law is a negative one, such as the obligation not to conduct searches and seizures without a warrant. ${ }^{228}$ Nor is standing defeated by the fact that the treaty is also designed to protect Mexico and the United States as states and more broadly to ensure international order. Treaties, like all laws, may seek to advance the interests of the community as a whole by conferring primary rights on particular individuals. That a treaty is designed to protect societies and promote order by allocating governmental powers does not mean that it does not also confer primary rights. The Supreme Court recently so held in Dennis $v$. Higgins ${ }^{229}$ in the context of defining a "right" for purposes of section 1983. It was argued in Dennis that the Commerce Clause of the federal Constitution does not confer "rights" on individuals but rather is merely a "power-allocating" provision. ${ }^{280}$ The Court agreed that the clause was a power-allocating provision, but held that the clause also confers "rights" on individuals to engage in interstate commerce without being subjected to state regulation running afoul of the clause. ${ }^{231}$ Similarly, the extradition treaty's prohibition of unilateral abductions of Mexican citizens from Mexico not only allocates power territorially between the United States and Mexico, it also confers a primary right on citizens of both countries not to be subjected to deprivations of liberty by the other state while in their home state's territory. ${ }^{232}$

a much criticized decision, that the fact that a criminal defendant was brought to the jurisdiction in violation of the Federal Kidnapping Act, 18 U.S.C. § 1201 (1988 \& Supp. 1991), did not deprive the criminal court of jurisdiction. See Frisbie v. Collins, 342 U.S. 519, 522-23 (1951). It did not, however, question the defendant's standing. It merely declined to add to the sanctions specifically provided in the Act "a sanction barring a state from prosecuting persons wrongfully brought to it by its officers." Id. at 523 .

227. See supra text accompanying notes 233.

228. See U.S. Const. amend. IV. That is not to say that anyone harmed by such a search has standing to challenge it. See cases cited infra note 245 .

229. 111 S. Ct. 865 (I991).

230. Id. at 870 .

231. Id. at 871-72. The Court said that it had already rejected the contrary argument in a prior case in which it held that individuals were within the "zone of interests" protected by the Commerce Clause. Id. at 872 (citing Boston Stock Exch. v. State Tax Comm'n, 429 U.S. 318, 321 n.3 (1977)); accord Monaghan, supra note 26, at 246 (the purported dichotomy between distribution of power and establishment of personal rights is illusory).

232. In Verdugo, the Ninth Circuit held that, when the state from which the defendant was abducted protests the abduction, the defendant has derivative standing to assert the rule against unilateral abductions. See United States v. Verdugo-Urquídez, 939 F.2d 1341, 1355-57 (9th Cir. 1991). Under the analysis proposed here, however, there would be no need to resort to a notion of derivative standing. Derivative standing is necessary if the right being asserted is not one's own. It is true that only Mexico has 
Nor does the fact that only the state may enforce treaty obligations at the international plane, or that the state may waive obligation, mean that individuals lack primary rights under the treaty for domestic purposes. ${ }^{233}$ Until recently, this could be said of all treaties. ${ }^{234}$ These are the qualities of treaties under international law that have led commentators to conclude that they do not confer "rights" on individuals. But it was precisely these qualities of treaties that the Framers sought to alter (or make irrelevant) for domestic purposes when they adopted the Supremacy Clause. ${ }^{235}$

1t may be that many treaties will lie entirely beyond judicial cognizance because they are intended to benefit only states as states, rather than individuals. For example, it is difficult to imagine a circumstance in which an individual would have standing to enforce a disarmament treaty. Even the person with the contract to remove the weapons cannot be said to be a direct or intended beneficiary of such a treaty. ${ }^{236}$ But that is because such a treaty was only intended to benefit society as a whole, rather than individuals within it. ${ }^{237}$ Treaties that do address the parties' treatment of individuals, however, should not be considered

secondary rights under the extradition treaty as a matter of international law, but that does not mean that an individual cannot enforce the treaty in our courts. See supra note 50. In the statutory context, standing rules determine whether an individual has a primary right under a law. If the court had applied such rules, it would have had little difficulty concluding that Verdugo had standing. After conducting such a standing analysis, the court's conclusion would have been that the individual had a "right" under the treaty as a matter of domestic law. The court's mistake was to begin by assuming that Verdugo did not have a right under domestic law because he did not have a right under international law.

233. The "right" is a type of right of asylum. See United States v. Rauscher, I I9 U.S. 407,420 (1886). It is thus, by definition, a right not to be subjected to the enforcement jurisdiction of states other than, in this instance, Mexico. It is a right vis-àvis states other than Mexico. The fact that the right may be "defeasible" by Mexico does not negate its status as a right vis-à-vis the United States.

234. See supra note 50 .

235. If the state of the individual's nationality did in fact waive the obligation before it was allegedly violated, then the individual would be without a claim. Perhaps the result should be the same if the state waives the obligation after the violation. However, the Ninth Circuit's holding in Verdugo that an individual has standing to enforce the obligation only if the state of his nationality affirmatively protests, see 939 F.2d at I352, is effectively a conclusive presumption that unless the state affirmatively protests it will be deemed to have waived the obligation. In no other context does an individual's ability to enforce a treaty in a domestic court turn on an affirmative demonstration that the state has not waived the obligation. See supra note 50 .

236. See Lujan v. National Wildlife Fed'n, I I0 S. Ct. 3177,3186 (1990) (dicta).

237. Although a citizen of one of the states may have an interest in compliance with the treaty, it has long been established that a "minute and indeterminable" interest, Frothingham v. Mellon, 262 U.S. 447, 487 (I923), or an interest that is indistinguishable from that of the general public, or an interest that is purely ideological, is insufficient to entitle an individual to enforce a law. See Allen v. Wright, 468 U.S. 737, 753-56 (I984); Sierra Club v. Morton, 405 U.S. 727, 735-4I, (1972); Frothingham, 262 U.S. at 468-88. 
unenforceable by individuals merely because their purpose is also to benefit society as a whole.

In summary, standing doctrine addresses the same issue that the courts sometimes address as a "self-execution" issue: whether the duty imposed by the treaty gives rise to a correlative primary right of the litigant such that the litigant may enforce the rule in court. In the domestic standing context, the conclusion by a court that the litigant has standing is effectively a determination that the litigant has a primary right under the applicable law. The same is true when the obligation being enforced has its source in a treaty. Once standing has been found, there should be no need to inquire further whether the litigant has a "right" under the treaty. Where a treaty requires a state to behave in a given way towards an individual, that individual will have a correlative primary right and thus standing. Where the connection between the state's obligation and the individual is less direct, the individual's standing will turn on whether he was an intended beneficiary of the obligation.

2. Rights of Action and Remedial Rights. - The relationship among the concepts "right of action,"238 "remedy," and "standing" has been the subject of considerable uncertainty. Hart and Sacks define a right of action as the "capacity to invoke the judgment of a tribunal of authoritative application upon a disputed question about the application of preexisting arrangements and to secure, if the claim proves to be well-founded, an appropriate official remedy."239 So conceived, a right of action is the right to obtain some remedy from a tribunal. One may have a right of action and yet not be entitled to the particular remedy one seeks. But if one is entitled to a remedy, one necessarily has a right of action, unless the remedy is purely defensive. In the cases that discuss when a private right of action exists under a statute, the Court uses the term as if it were synonymous with private remedy. ${ }^{240}$

The Supreme Court has said that the standing question is "closely related" to the right of action question, and that, apart from Article III considerations, the former asks "[e]ssentially" whether the legal provision can be understood as granting the plaintiff "a right to judicial relief."241 But on other occasions it has distinguished standing, rights of action, and remedies. ${ }^{242}$ Hart and Sacks distinguish a primary right

238. The courts appear to use the terms "right of action" and "cause of action" interchangeably. I use them interchangeably here.

239. Hart \& Sacks, supra note 26, at 154.

240. See, e.g., Northwest Airlines, Inc. v. Transport Workers Union, 451 U.S. 77, 91 (1981); Transamerica Mortgage Advisors, Inc. v. Lewis, 444 U.S. 11, 15-16 (1979).

241. Warth v. Seldin, 422 U.S. 490,500 (1975).

242. In Davis v. Passman, 442 U.S. 228 (1979), the Court distinguished the concepts as follows:

[S]landing is a question of whether a plaintiff is sufficiently adversary to a defendant to create an Art. III case or controversy, or at least to overcome prudential limitations on federal-court jurisdiction; cause of action is a question 
from a right of action, and they argue that the former does not necessarily carry with it the latter. ${ }^{243}$ They regard a primary right as a necessary but not sufficient condition of a right of action. This appears to be consistent with the recent decisions of the Supreme Court taking a selfconsciously more restrictive approach to inferring rights of action from statutes. It is, however, in tension with the common law maxim that "where there is a legal right, there is a legal remedy,"244 as well as with the sanctionist view that a right without a remedy is not a legal right. As discussed below, the tension is relieved significantly, with respect to primary rights against the government, by statutes, the common law, and the Due Process Clause.

Although the particulars of the relationship are unsettled, the Court's decisions do permit some observations about the relationship among the concepts of standing, right of action, and remedy. A litigant has to establish a right of action only if he is seeking to maintain an action; a right of action is unnecessary if one is invoking a legal provision as a defense. When it has been determined that a right of action exists to enforce a particular law or when a law is being invoked as a defense, it may nevertheless be necessary to establish that a particular class of litigants has standing ${ }^{245}$ and that the remedy being sought is the appropriate one. ${ }^{246}$ But a determination that a litigant is entitled to

of whether a particular plaintiff is a member of the class of litigants that may, as a matter of law, appropriately invoke the power of the court; and relief is a question of the various remedies a federal court may make available. A plaintiff may have a cause of action even though he be entitled to no relief at all, as, for example, when a plaintiff sues for declaratory or injunctive relief although his case does not fulfill the 'preconditions' for such equitable remedies.

Id. at 239-40 n.18 (1979) (citations omitted). In Franklin v. Gwinnett County Pub. Sch., 112 S. Ct. 1028, 1033-35 (1992), the Court recently insisted on this distinction between rights of action and relief, holding that while the courts' implication of rights of action from statutes may raise separation of powers issues, no such problems are raised by their determination that a particular form of relief is available under a statute that confers a right of action but does not specify the remedy.

243. See supra text accompanying notes $40-42$.

244. See 112 S. Ct. at 1033.

245. Standing issues may arise when laws are invoked by defendants as well as plaintiffs. See, e.g., United States v. Salvucci, 448 U.S. 83, 86-89 (1980); United States v. Payner, 447 U.S. 727, 731-33 (1980); Alderman v. United States, 394 U.S. 165, $171-76$ (1969).

246. Thus, since Verdugo was a defendant and had shown that he had standing to invoke the treaty, he did not have to show further that he had a right of action. The court, however, properly required him to show that the appropriate remedy for the government's violation of its duty was his repatriation. See supra note 10. Similarly, defenders of the exclusionary rule argue that exclusion of evidence is the appropriate remedy for violations of the Fourth Amendment, yet it has not been thought that the defendant needed a right of action to invoke the Fourth Amendment for the purpose of excluding evidence. With respect to both the extradition treaty in Verdugo and the Fourth Amendment, however, a litigant would need a right of action if he were to bring a lawsuit seeking damages for violations of the state's duty. In both cases the litigant would have to demonstrate his standing to enforce the legal provision. 
a particular remedy is necessarily a determination that the litigant has a right of action for that remedy, unless the remedy is purely defensive. ${ }^{247}$ And a determination that a particular class of litigants has a right of action or is entitled to a remedy is necessarily a determination that such litigants have standing.

a. Rights of Action. - Numerous lower courts have held that a treaty is "self-executing" only if it creates a private right of action, and they determine whether a treaty confers such a right of action by looking for evidence of an intent of the parties or of the U.S. treaty makers to create such a right of action. ${ }^{248}$ If they do not find such evidence, they conclude that the treaty is not "self-executing" and accordingly need not be considered by the court. But, although a treaty that does not itself confer a right of action may for that reason be described as not self-executing with respect to remedies, ${ }^{249}$ such a treaty is not for that reason unenforceable in the courts. A right of action is not necessary if the treaty is being invoked as a defense. Moreover, treaties have long been enforced pursuant to common law forms of action. Furthermore, there are a number of possible federal statutory bases for rights of action to enforce treaties, the most important being section 1983 and the APA. Only if there is no other basis for the right of action should it be necessary to locate a right of action in the treaty itself. If the treaty expressly entitles the individual to a remedy, he is entitled to that remedy by virtue of the Supremacy Clause. If the treaty does not expressly entitle the individual to a remedy, a remedy should nevertheless be considered to be implicit in the treaty whenever failure to afford the individual the remedy would give rise to international responsibility of the United States to the state of the individual's nationality.

A right of action is not necessary to invoke a treaty as a defense. For example, it is clear that the Framers intended that a treaty would nullify any inconsistent state law, and that a treaty supersedes an earlier federal statute. ${ }^{250}$ Thus, a defendant being prosecuted or sued under a state or prior federal law that is inconsistent with a treaty is entitled to invoke the treaty in court to nullify the state or federal law without having to show that the treaty confers a private right of action.251 Moreover, the Due Process Clause ordinarily requires that a government deprivation of property or liberty be preceded by a hearing. Thus, even if the beneficiary of a treaty-based primary right were deemed not to possess a right of action, he would nevertheless be free to resist a

247. See Edwin M. Borchard, Declaratory Judgments 16 (1934) ("[T]hat the grant of any [remedy] would necessarily presuppose a cause of action can hardly be doubted.").

248. See cases cited supra note 137.

249. See supra text accompanying notes 130-131.

250. The Cherokee Tobacco, 78 U.S. (11 Wall.) 616, 621 (1870).

251. See, e.g., Kolovrat v. Oregon, 366 U.S. 187, 197 (1961); Patsone v. Pennsylvania, 232 U.S. 138, 145 (1914). 
deprivation of liberty or property that violates the treaty and to invoke the treaty as a defense to a government coercive proceeding. ${ }^{252}$ The Supremacy Clause, by nullifying inconsistent official action, and the Due Process Clause, by requiring a hearing at which the action can be challenged (either offensively or defensively), furnish the legal sanction that a strict sanctionist would consider an essential attribute of a law and a legal right.

Even a litigant invoking a treaty in an action to obtain affirmative relief may not have to show that the treaty confers a right of action. Federal law, including treaty-based law, "is interstitial in its nature."253 All federal law is enacted "against the background of the total corpus juris of the states." 254 As with federal statutes, it is not unusual for "substantive rights [to] be defined by [treaty] but the remedies for their enforcement left undefined or relegated wholly to the states."255 Treaties imposing primary duties without specifying remedies, like similar federal statutory and constitutional provisions, have long been given effect through common law forms of action. In most of the nineteenth century treaty cases, the "right of action" of the party relying on the treaty was supplied by the common law; the treaty simply supplied the rule of decision. Thus, in Ware $v$. Hylton, ${ }^{256}$ the plaintiff was suing to recover a debt. The treaty merely nullified the defendant's defense of payment. In Foster $v$. Neilson, ${ }^{257}$ the plaintiff brought a suit in the nature of ejectment, and the treaty was relevant in determining who had title to the property. ${ }^{258}$

In suits against the government, too, the right of action might have its source in the common law. If government action that assertedly violates federal law also constitutes a tort under state law or would otherwise entitle an individual to relief under the common law if performed by a private person, the individual may sue the official (state or federal) in his personal capacity, for either legal ${ }^{259}$ or equita-

252. On the constitutional right to a hearing and a judicial forum, see infra text accompanying notes 288-294.

253. Hart \& Wechsler, supra note 128 , at 533.

254. Id.

255. Id.

256. 3 U.S. (3 Dall.) 199 (1796).

257. 27 U.S. (2 Pet.) 253 (1829).

258. See id. at 314-15; see also Florida v. Furman, 180 U.S. 402, 428 (1901) (action to remove cloud on legal title); Botiller v. Dominguez, 130 U.S. 238, 243 (1889) (ejectment); Hauenstein v. Lynham, 100 U.S. 483, 485 (1879) (action "pursuant to a law of the State"); Orr v. Hodgson, 17 U.S. (4 Wheat.) 453, 462-63 (1819) (bill in equity); Chirac v. Chirac, 15 U.S. (2 Wheat.) 259, 277 (1817) (ejectment); Harden v. Fisher, 14 U.S. (1 Wheat.) 300,303 (1816) (same).

259. The Federal Employees Liability Reform and Tort Compensation Act of 1988, 28 U.S.C. $\$ \S 2671-2680$ (1988), preempted state-law tort suits against federal officers for money damages, substituting in its place a suit against the United States under the Federal Tort Claims Act. See United States v. Smith, 111 S. Ct. 1180,1189 (1991). On the FTCA, see infra note 275. 
ble 260 relief, on a common law theory. 261 The officer in such a case would be treated as a private person, and the violation of federal law would serve to nullify any defense of justification. ${ }^{262}$ Until relatively recently, most damage actions against federal or state officials predicated on acts that were alleged to violate federal statutory or constitutional provisions took this form. ${ }^{263}$ In this manner, state law ${ }^{264}$ may provide the right of action for enforcing treaty-based primary rights against state ${ }^{265}$ and, to the extent not preempted by federal law, federal

260. Until 1988, state courts could entertain an action against a federal officer for damages or for "legal" remedies that resembled injunctions, such as replevin and ejectment, but not for mandamus or habeas corpus. See Richard Arnold, The Power of State Courts to Enjoin Federal Officers, 73 Yale L.J. 1385, 1394-95 (1964). The decisions regarding the power of state courts to enter an injunction against a federal officer were, however, "in confusion." See id. (arguing that state courts do have the power); see also Herbert Wechsler, Federal Jurisdiction and the Revision of the Judicial Code, 13 Law \& Contemp. Probs. 216, 220 (1948) ("[lt is] doubtful whether state courts are empowered to restrain the action of a federal official taken under color of federal law."). But see infra note 293 (structuralist arguments for the ability of state courts to enjoin federal officers). In 1988, Congress preempted state-law suits against federal officials for money damages, making the Federal Tort Claims Act the exclusive remedy for obtaining money damages for injuries caused by federal officials. See supra note 259. Suits under the FTCA may be maintained only in federal court. See 28 U.S.C. $\S 1346$ (b) (1988). State courts presumably retain the power to entertain suits in the nature of replevin and ejectment. Moreover, they retain whatever power they possessed to enter injunctions against federal officials. In any event, to say that a state court may not enjoin a federal official is not to say that state law may not afford a "right of action" to enjoin a federal official, an action maintainable only in federal court. Federal courts before Erie awarded damages against federal officials pursuant to what we today consider state-law rights of action, see infra note 261 , and they enjoined threatened federal official action that would infringe rights protected by the common law and for which the officer would be held liable in damages if the act were completed, see infra note 282.

261. See, e.g., Mitchell v. Harmony, 54 U.S. (13 How.) 115, 132 (1851); Elliott v. Swartwout, 35 U.S. (10 Pet.) 137 (1836) (assumpsit).

262. The officer who violates federal law is "stripped of his official or representative character and is subjected in his person to the consequences of his individual conduct." Ex parte Young, 209 U.S. 123, 160 (1908) (explanation for inapplicability of Eleventh Amendment). Nevertheless, the officer is entitled to a qualified immunity from suit for damages. See Hart \& Wechsler, supra note 128, at $1277-1307$.

263. See Walter E. Dellinger, Of Rights and Remedies: The Constitution as a Sword, 85 Harv. L. Rev. 1532, 1541-45 (1972); Hill, supra note 130, at I 124-28; Katz, supra note 27 , at $48-51$.

264. Because the decisions cited supra notes 258 and 261 and infra note 266 were pre-Erie, they do not specify whether the rights of action were based on federal or state common law. Today, we would consider these actions, when brought against private defendants, to be based on state law. To the extent not preempted by federal statute, the actions against federal officials might alternatively be thought to be.based on federal common law. See infra note 284.

265. See, e.g., Jordan v. Tashiro, 278 U.S. 123, 125 (1928) (state mandamus action against California secretary of state); Asakura v. City of Seattle, 265 U.S. 332, 340 (1924) (state action for an injunction against city). 
officials. ${ }^{266}$ If the litigant bases his action on state law, however, the right to recovery could depend on the vicissitudes of the relevant state law. For this and other reasons, ${ }^{267}$ the litigant may prefer to base his action on federal law.

Treaties are enacted against a background not only of state law, but also of federal statutes authorizing the courts to award remedies for the violation of federal laws generally. There are a variety of possible federal bases for actions against state or federal officials predicated on an alleged violation of a treaty provision. The most important ones are section 1983 and the APA.

Section 1983 confers a right of action for damages and injunctive or declaratory relief on persons who have been deprived under color of state law "of any rights, privileges, or immunities secured by the Con-

266. A number of federal decisions recognize that the common law may provide a right of action against federal officers whose conduct allegedly violates a treaty. In Curtis v. Fiedler, 67 U.S. (2 Black) 461 (1862), the Supreme Court dismissed an action in assumpsit against a federal collector of customs for the recovery of duties that were allegedly collected in violation of a treaty with Russia. The suit was dismissed on the ground that Congress had withdrawn that remedy by statute, but the Court said that "[p]rior to the passage of that act, it had frequently been held that an action of assumpsit would lie against a collector to recover back duties illegally exacted by him of the importer." Id. at 478. The Court did not distinguish between duties that were illegally exacted because they violated a treaty and those illegally exacted for some other reason. Similarly, Whitney v. Robertson, 124 U.S. 190 (1888), Head Money Cases, 18 F. 135, aff'd, 112 U.S. 580 (1884), and Taylor v. Morton, 23 F. Cas. 784 (C.C.D. Mass. 1855) (No. 13,799) were all actions in assumpsit against federal customs collectors for the recovery of duties allegedly collected in violation of treaties. The actions were all dismissed on the ground that the treaties involved had been superseded by statute, but in none of the cases was the availability of a right of action against the official at common law questioned. Cf. DeLima v. Bidwell, 182 U.S. 1, 220 (1900), in which the Court held that a suit in assumpsit would lie against a customs collector for the recovery of duties that were claimed to have been unlawfully exacted; because the goods had been shipped from Puerto Rico, which, by virtue of a treaty, had become part of the United States, they had not been imported from a "foreign country" and accordingly there was no authority for their collection. Id. at 180-81.

Recent amendments to the Federal Tort Claims Act, however, purport to preempt state-law damage actions against federal officials. See supra note 259; infra note 275. On the role of state law in affording a right of action against federal officials for nonmonetary relief, see infra notes $282-283$ and accompanying text.

267. For example, the litigant may prefer to be in federal court. Recent Supreme Court decisions on the general federal question statute establish that federal jurisdiction may not exist under that statute if the federal law establishing the primary right is not enforceable through a federal right of action. See Merrell Dow Pharmaceuticals Inc. v. Thompson, 478 U.S. 804 (1986). However, federal jurisdiction over a tort suit against a federal or state official would be available under the Alien Tort Statute, 28 U.S.C. $\S 1350$ (1981), if the official's act violates a treaty. That statute provides that "[ $t]$ he district courts shall have original jurisdiction of any civil action by an alien for a tort only, committed in violation of the law of nations or a treaty of the United States." Id. Moreover, a federal official sued in state courts would be able to remove to federal court if his defense is based on federal law. See Mesa v. California, 109 S. Ct. 959 (1989). 
stitution and laws" of the United States. ${ }^{268}$ Because treaties are "Law of the Land" under the Supremacy Clause, they fall within the terms of that statute. In Maine $v$. Thiboutot, ${ }^{269}$ the Court rejected the argument that the term "laws" in section 1983 "should be limited to some subset of laws."270 In the majority and dissenting opinions in Baldwin $v$. Franks, ${ }^{271}$ it was common ground among the Justices that the term "law" in a closely related provision of the Civil Rights Act of 1870 included "a treaty between this Government and a foreign nation."272 The lower courts that have considered the issue have concluded that section 1983 confers a right of action for violation of treaty-based rights. ${ }^{273}$

Section 702 of the APA provides that "[a] person suffering legal wrong because of [federal] agency action, or adversely affected or aggrieved by agency action within the meaning of a relevant statute, is entitled to judicial review thereof." 274 This provision affords a right of action for equitable or declaratory relief ${ }^{275}$ challenging the actions of

\author{
268. 42 U.S.C. $\S 1983$ (1988). \\ 269. 448 U.S. 1 (1980). \\ 270. Id. at 4 . \\ 271. 120 U.S. 678 (1887).
}

272. 1d. at 695 (Harlan, J., dissenting) (noting that this was "conceded" by the majority). Baldwin involved section 5508 (now 18 U.S.C. $\$ 241$ (1988)), which provided that "[i]f two or more persons conspire to injure, oppress, threaten, or intimidate any citizen in the free exercise or enjoyment of any right or privilege secured to him by the Constitution or laws of the United States, ... they shall be fined not more than five thousand dollars, and imprisoned not more than ten years . . .." Id. at 684; accord Chapman v. Houston Welfare Rights Org., 441 U.S. 600, 661 n.36 (1979) (White, J., concurring) (noting that the Court in Baldwin concluded that discrimination against an alien in contravention of a treaty "would be within the proscription of $\S 241$ but for the language in that statute limiting its application to denials of the rights of 'citizens" "). On the relationship between $\S 241$ and $\S 1983$, see id. at $661,654-63$ (because $\S 241$ and $\S 1983$ are "analogous" and "describe[] the rights protected in language [that is] nearly identical," they should be read to be coextensive). But cf. id. at 623-44 (Powell, J., concurring) (although the term "laws" in $\$ 241$ includes all federal laws, the term in $\S 1983$ extends only to laws relating to equal rights). Justice Powell's position was later rejected in Thiboutot, 448 U.S. at 1.

273. See Romero v. Kitsap County, 931 F.2d 624, 626 (9th Cir. 1991); Hoopa Valley Tribe v. Nevins, 881 F.2d 657, 661-63 (9th Cir. 1989), cert. denied, 110 S. Ct. 1523 (1990); Note, Judicial Enforcement of International Law Against the Federal and State Governments, 104 Harv. L. Rev. 1269, 1272 \& n.28 (1991).

274. 5 U.S.C. $\$ 702$ (1988).

275. Suits against the United States seeking damages for injuries caused by federal officials are permitted in certain circumstances by the Federal Tort Claims Act, 28 U.S.C. $\$ \S 1346,1402(b), 1504,2110,2401-2402,2411-2412,2671-2680$ (1988). In 1988, Congress broadened the grounds on which damages could be recovered against the United States under the Act, but at the same time it provided that the Act would thenceforth be the exclusive basis of obtaining money damages as the result of injuries caused by the actions of federal officers that do not violate the Constitution. See supra note 259. Accordingly, suits against federal officers for money damages for injuries caused by violation of treaties can no longer be pursued on a state law or federalcommon-law tort theory. Suits against such officers for equitable relief or "legal" relief 
federal agencies or officials as contrary to law. ${ }^{276}$ Treaties are of course federal law and their violation thus produces a "legal wrong." Accordingly, the APA has been read by the courts to authorize judicial review of federal agency action that allegedly violates a treaty. ${ }^{277}$

These decisions are undoubtedly correct. Although the APA is today considered the statutory basis of a federal right of action, ${ }^{278}$ the action for judicial review of federal agency action did not originate with the APA. ${ }^{279}$ Before the enactment of the APA, judicial review was available in an action against the officer personally. ${ }^{280}$ Independently of the APA, it was a "familiar principle that executive officers [could] be restrained from threatened wrongs in the ordinary courts in the absence of some exclusive alternate remedy."281 This "right of action" for judicial review has been thought to have its basis in some combina-

other than money damages, however, are not preempted by the FTCA. See supra note 260.

276. See Japan Whaling Ass'n v. American Cetacean Soc'y, 478 U.S. 221, 230 n.4 (1986).

277. See Sohappy v. Hodel, 911 F.2d 1312, 1316-17 (9th Cir. 1990); Makah Indian Tribe v. Verity, 910 F.2d 555, 557 (9th Cir. 1990); Committee of U.S. Citizens Living in Nicar. v. Reagan, 859 F.2d 929, 942-43 (D.C. Cir. 1988) (dictum); Flynn v. Shultz, 748 F.2d 1186, 1191-94 (7th Cir. 1984), cert. denied, 474 U.S. 830 (1985); Rainbow Navigation, Inc. v. Department of the Navy, 686 F. Supp. 354,356 n.10 (D.D.C. 1988), aff'd, 783 F.2d 1072 (1986); cf.Japan Whaling, 478 U.S. at 230-31 n.4 (APA provides the "right of action" in suit seeking to enforce statute requiring the Secretary of Commerce to certify that Japan's conduct "diminishes the effectiveness" of treaty).

278. See Japan Whaling, 478 U.S. at 230 n.4.

279. See Attorney General's Manual on the Administrative Procedure Act 95-96 (1947), reprinted in Tom C. Clark, I.C.C. Practitioner's J., Feb. 1948, § 11, at 5.

1 refer in the discussion that follows to what is known as nonstatutory review, that is, review of agency action not based on the terms of a statute relating specifically to that agency. See Clark Byse \& Joseph V. Fiocca, Section 1361 of the Mandamus and Venue Act of 1962 and "Nonstatutory" Judicial Review of Federal Administrative Action, 81 Harv. L. Rev. 308 (1967) (discussing nonstatutory review of federal agency action). Review of treaty-based claims might be authorized independently by an agency's organic statute. Review might additionally be available under statutes authorizing particular forms of relief other than injunctive or declaratory relief. There are numerous such statutes that would authorize particular remedies in particular contexts for treaty violations. For example, a writ of habeas corpus may be granted to persons "in custody in violation of the Constitution or laws or treaties of the United States." 28 U.S.C. $\S 2241$ (1988); see generally Stephen G. Breyer \& Richard B. Stewart, Administrative Law and Regulatory Policy 969-74 (1992) (discussing certiorari, mandamus, and other writs). The Alien Tort Statute, 28 U.S.C. $\$ 1350$ (1981), might also be read to authorize tort remedies for actions of federal or state officials that violate treaties. (1902).

280. See, e.g., American Sch. of Maguetic Healing v. McAnnulty, 187 U.S. 94

281. Stark v. Wickard, 321 U.S. 288, 290 (1944); accord Harmon v. Brucker, 355 U.S. 579, 581-82 (1958) ("Generally, judicial relief is available to one who has been injured by an act of a government official which is in excess of his express or implied powers."). 
tion of the common law, ${ }^{282}$ either state ${ }^{283}$ or federal; ${ }^{284}$ a jurisdictional statute, such as the general federal question statute; ${ }^{285}$ and the All Writs Act. ${ }^{286}$ The right of action to enjoin state or federal action that

282. See Attorney General's Comm. on Admin. Procedure, Administrative Procedure in Government Agencies, S. Doc. No. 8, 77th Cong., 1st Sess. 80 (1941). The Report does not specify whether it was referring to state or federal common law. The issue was less important in the days before Erie R.R. v. Tompkins, 304 U.S. 64 (1938); Cort v. Ash, 422 U.S. 66 (1975); and Merrell Dow Pharmaceuticals, Inc. v. Thompson, 478 U.S. 804 (1986).

283. Federal jurisdiction was sometimes based on diversity of citizenship. See Mitchell v. Harmony, 54 U.S. (13 How.) 115 (1851). Where diversity did not exist, "the federal courts [gave] the 'arising under' requirement a liberal interpretation in nonstatutory review actions." Byse \& Fiocca, supra note 279, at 323 . The recognition that the APA establishes a federal right of action, see Japan Whaling Ass'n v. American Cetacean Soc'y, 478 U.S. 221, 230 n.4 (1986), obviates the jurisdictional problem.

284. See Breyer \& Stewart, supra note 279 , at 976 :

If no specific statutory review is provided in the relevant organic statute, plaintiffs may seek review under more general principles of administrative law-principles that allow them to prevent unlawful governmental action or to obtain redress when they have been injured. As a result of Erie R.R. v. Tompkins, federal courts no longer exercise any general common law jurisdiction to redress torts by government officials. But ... federal courts have continued the private law model of administrative law by developing special federal law remedies for official activities that would also constitute common law torts. Nevertheless, a plaintiff must still find a statute that provides a federal court with jurisdiction to hear his or her claim. The most obvious choice is $\ldots 28$ U.S.C. $\$ 1331 \ldots$.

285. See Stark, 321 U.S. at 310 ("The responsibility of determining the limits of statutory grants of authority [to protect justiciable individual rights] . . . is a judicial function entrusted to the courts by Congress by the statutes establishing courts and marking their jurisdiction."); Louis L. Jaffe, The Right to Judicial Review, 71 Harv. L. Rev. 401, 432 (1958) ("Judicial review ... rests on the congressional grant of general jurisdiction to the article IIl courts."); see also Califano v. Yamasaki, 442 U.S. 682, 705 (1979) ("Absent the clearest command to the contrary from Congress, federal courts retain their equitable power to issue injunctions in suits over which they have jurisdiction."); Huie v. Bowen, 788 F.2d 698, 704 (11th Gir. 1987) ("Once jurisdiction is established, courts maintain the authority to provide equitable relief commensurate to the barm."); Breyer \& Stewart, supra note 279 (common law and jurisdictional statute); Antonin Scalia, Sovereign Immunity and Nonstatutory Review of Federal Administrative Action: Some Conclusions from the Public-Lands Cases, 68 Mich. L. Rev. 867, 870 n. 12 (1970) (general federal question statute and All Writs Act). With respect to actions alleging treaty violations, the Alien Tort Statute may provide authority for judicial review. See supra note 267.

286. 28 U.S.C. § I651 (1981). See Scalia, supra note 285 , at 870 n.12. In his dissenting opinion in Carlson v. Green, 446 U.S. 14 (1980), then-Justice Rehnquist distinguished the courts' ability to imply rights of action for damages, which he thought was limited in the absence of congressional authorization, from their power to entertain actions seeking equitable relief, which "federal courts have historically had broad power to fashion." Id. at 42. The litigant need only show "a right and a violation" (and presumably also jurisdiction) to trigger this equitable power. 1d. (quoting Swann v. Charlotte-Mecklenburg Bd. of Educ., 402 U.S. 1, 15 (1971)). Because he was discussing the availability of a right of action for equitable relief, his reference to "right" here is obviously a reference to a primary right. He attributes the right of action recognized in Ex parte Young, 209 U.S. 123 (1908)-to enjoin violations of the Constitution by state 
violates federal law might also be thought to be a concomitant of the Supremacy Clause's invalidation of such action, as the "customary legal incidents of voidness" include "the availability of a suit for rescission or for an injunction."287

The right of action for judicial review of federal agency action for conformity with federal law also has constitutional underpinnings. The Due Process Clause of the Fifth Amendment requires that deprivations of property or liberty by the federal government be either preceded or followed by a hearing. ${ }^{288}$ Although the hearing need not initially be in

officers-to this broad equitable jurisdiction of the federal courts. See 446 U.S. at 43. In contrasting the courts' power to award damages, he noted the inapplicability to damage actions of the All Writs Act, thus suggesting obliquely that the broad equitable powers of the federal courts have their source in that statute. See id.

The Declaratory Judgment Act, 28 U.S.C. $\$ 2201$ (1988), would supply the equivalent statutory basis for actions for declaratory relief. See United States v. Fausto, 484 U.S. 439, 444 (I988) (suits for declaratory judgment among the "forms of action traditionally used for so-called nonstatutory review of agency action"). Professor Monaghan has recently written that the Declaratory Judgment Act, being remedial only, was not meant "to dispense with the need to establish a right of action." Monaghan, supra note 26 , at 238 . As he distinguishes a right of action from a primary right, his statement suggests that the combination of a primary right under a treaty and a remedy under the Declaratory Judgment Act is an insufficient basis for maintaining an action for a declaration of a violation of federal law. The authorities he cites, however, discuss only the Act's effect on federal jurisdiction. Id. They establish that, if the primary right that the plaintiff seeks to vindicate through his action, disregarding anticipated defenses, does not rest on federal law, federal jurisdiction is lacking even though the declaratory remedy is authorized by federal law. See Skelly Oil Co. v. Phillips Petroleum Co., 339 U.S. 667 (1950). It does not follow that federal jurisdiction would be lacking if the plaintiff were to seek a declaration to vindicate a primary right afforded by federal law. In any event, leaving aside the question of federal jurisdiction, the cases are consistent with the conclusion that a plaintiff seeking a declaration that agency action violates federal law need not show more than a primary right under federal law and the availability of a remedy under the Declaratory Judgment Act. Cf. Shaw v. Delta Air Lines, Inc., 463 U.S. 85, 96 n.14 (1983) (entertaining action for a declaration that state statute preempted by federal statute). Today, a similarly situated plaintiff would be able to rely on section 1983 for his right of action, see Golden State Transit Corp. v. City of Los Angeles, 110 S. Ct. 444, 448 (1989), but at that time the issue was unsettled. The Court did not discuss the right of action issue, but it held that the case arose under federal law.

The co-drafter of the Declaratory Judgment Act has written that to maintain an action for a declaration, one must possess a "cause of action," but he uses the latter term in the sense of "legal interest," a concept that combines notions of ripeness and standing: "[A declaratory judgment plaintiff] must show that his rights are in direct issue or jeopardy; and incidental thereto, must show that the facts are sufficiently complete, mature, proximate, and ripe to place him in gear with his adversary, and thus to warrant the grant of judicial relief." Borchard, supra note 247 , at 36 .

287. Transamerica Mortgage Advisors, Inc. v. Lewis, 444 U.S. 11, 19 (1979) (implying a right of action for rescission and injunction from a federal law declaring certain private contracts void).

288. This is clearly the case when the liberty or property interest is not itself defined by federal statute or treaty, such as when the state physically restrains an individual or takes away his tangible property. See Oestereich v. Selective Serv. Sys. 
a court, if Congress provides for an initial hearing by administrative agencies or non-Article III courts, some measure of review by an Article III court - or perhaps a state court-is thought to be required either by Article III ${ }^{289}$ or by the Due Process Clause itself. ${ }^{290}$ Judicial review of executive deprivations of liberty or property for which an administrative hearing has not been provided would appear to be required a fortiori. The Due Process Clause thus ordinarily contemplates that government deprivations of primary rights will be either preceded or followed ${ }^{291}$ by an opportunity to test the legality of the deprivation in

Local Bd. No. 11, 393 U.S. 233, 243-44 n.6 (1968) (Harlan, J., concurring) (deprivations of "personal liberty" require either "prior opportunity to be heard" or "prompt subsequent hearing"). But a liberty or property interest may also be created by federal law, including treaty. In such circumstances, the power of Congress to limit the procedures available for the vindication of the treaty right might be thought to be broader, on the theory that, if Congress has the power to repeal the right entirely, it must have the lesser power of limiting the manner in which it may be enforced. On this theory, a total denial of a hearing might be construed as an implicit repeal of the substantive right. This ground for curtailing hearing rights within the agency has not yet commanded a majority in the Court, cf. Arnett v. Kennedy, 416 U.S. 134 (1974) (plurality opinion), but, as discussed infra note 294, it may be the unarticulated rationale for upholding preclusions of judicial review in certain circumstances. Cf. Davis v. Passman, 442 U.S. 228, 241 (1979) (noting that because "[s]tatutory rights and obligations are established by Congress ... it is entirely appropriate for Congress ... to determine ... who may enforce them and in what manner").

289. See Bator, supra note 188, at 267-68; see also Northern Pipeline Constr. Co. v. Marathon Pipe Line Co., 458 U.S. 50, 70 n.23 (1982) (plurality opinion) ("[W] Congress assigns [public rights] matters to administrative agencies, or to legislative courts, it has generally provided, and we have suggested that it may be required to provide, for Art. III judicial review.").

290. See Crowell v. Benson, 285 U.S. 22, 87 (1932) (Brandeis, J., dissenting); Hart \& Wechsler, supra note 128 , at 400 . The Supremacy Clause, in conjunction with Article III, generally requires that judicial review of agency action depriving persons of liberty or property encompass de novo review of the agency's interpretation of the law. See St. Joseph Stock Yards Co. v. United States, 298 U.S. 38, 84 (1936) (Brandeis, J., concurring) ("The supremacy of law demands that there shall be opportunity to have some court decide whether an erroneous rule of law was applied; and whether the proceeding in which facts were adjudicated was conducted regularly."). Hart writes that "[i]t's perfectly obvious that final authority to determine even questions of law can be given to executive or administrative officials in many situations not having the direct impact on private persons of a governmentally-created and judicially-enforceable duty, or of an immediate deprivation of liberty or property by extra-judicial action." Hart \& Wechsler, supra note 128, at 410 . These categories, however, would appear to cover only situations in which no "rights" are at stake either because there is no correlative duty or because no one was an intended beneficiary. See, e.g., Panama Canal Co. v. Grace Line, Inc., 356 U.S. 309, 318 (1958).

The deference that courts give to administrative interpretations of law is not inconsistent with the requirement of de novo review of issues of law: the agency's construction of the law is deferred to only to the extent the agency was delegated lawmaking power on the matter. To that extent, the law is what the agency says it is. See Monaghan, Marbury and the Administrative State, supra note 166, at 27-28. But the court's duty includes a duty to determine de novo whether the agency exceeded the scope of the delegation.

291. If a predeprivation hearing is not afforded, the Due Process Clause in certain 
court, either state ${ }^{292}$ or federal, ${ }^{293}$ at least if no administrative hearing has been afforded. Because of the constitutional problems that would arise if a right of action were not recognized, the Court requires that a congressional intent to preclude judicial review of federal agency action be expressed clearly. ${ }^{294}$

circumstances requires that a retrospective remedy be afforded the individual. See McKesson Corp. v. Division of Alcoholic Beverages \& Tobacco, 110 S. Ct. 2238 (1990). 292. Presumably, both the Due Process Clause and Article III would be satisfied if federal agency action were reviewable by state courts, as state court decisions on federal issues would be reviewable by the Supreme Court. But cf. supra note 260 (doubtful whether state courts may enjoin federal officer). Suits against federal officers commenced in state courts, however, will wind up in federal court if the officer is basing his defense on federal law and prefers to be in federal court. See 28 U.S.C. $\S 1442 a$ (1988); Mesa v. California, 109 S. Ct. 959 (1989).

293. In Webster v. Doe, 486 U.S. 592 (1988), Justice Scalia rejected the majority's contention that denying the litigant a federal forum for vindication of his constitutional rights would present constitutional problems: "The first response to the Court's grave doubt . . . is that the denial of all judicial review is not at issue here, but merely the denial of review in United States district courts." Id. at 611 (Scalia, J., dissenting). The Constitution's requirement of a judicial forum in certain circumstances, combined with the fact that the Constitution gives Congress the discretion not to establish lower federal courts, is a strong ground for concluding that the state courts do indeed bave the power to enjoin federal officials, at least if similar relief is not available in federal court. Cf. supra note 260 (state injunctions against federal officials).

294. See Webster, 486 U.S. at 603; see also Bowen v. Michigan Acad. of Family Physicians, 476 U.S. 667, $681 \mathrm{n} .12$ (1986). The Court in these cases referred to the serious constitutional questions that would arise if a judicial forum were denied for constitutional claims. As noted supra note 288, the constitutional problems with preclusion of review might be thought to be less severe with respect to action that allegedly deprives persons of property or liberty interests themselves created by federal statutes or treaties, on the ground that, if Congress has the power to withdraw the right entirely, it has the power to take the lesser step of limiting its enforceability. This analysis has not yet gained favor with the Court as a ground for limiting the right to a hearing within the agency, but it may be the unarticulated rationale for upholding the preclusion of all judicial review where Congress has placed statutory limits on the government's withdrawal of statutory benefits and provided for an administrative hearing. See, e.g., United States v. Fausto, 484 U.S. 439 (1988); United States v. Erika, Inc., 456 U.S. 201 (1982). Even with respect to statutory rights, however, preclusion of review presents constitutional problems if no administrative hearing is allowed. See Oestereich v. Selective Serv. Sys. Local Bd. No. I1, 393 U.S. 233, 243-44 (1968) (Harlan, J., concurring). In any event, the Court applies the presumption in favor of judicial review to nonconstitutional claims as well as constitutional ones (although perhaps not always to avoid constitutional questions). See Lindahl v. Office of Personnel Management, 470 U.S. 768, 778 (1985).

In certain contexts, preclusion of review bas been expressly upheld on the ground that Congress possesses extraordinary substantive powers in the field, and that therefore the Due Process Clause does not even apply. See Hart \& Wechsler, supra note 128, at 413-19 (describing the decisions regarding admission of aliens as drawing "distinctions between when the Constitution applies and when it does not apply at all"). On the applicability of the Constitution to unadmitted aliens, see Jean v. Nelson, 472 U.S. 846, 858 (1985) (Marshall, J., dissenting).

The extent of Congress' power to deny access to the courts for enforcement of treaty-based rights is beyond the scope of this Article. It is clear, however, that in this 
The pre-APA regime for obtaining judicial review of federal agency action gave rise to what many considered a "mass of confusion." 295 By enacting the APA and its 1976 amendments waiving the sovereign immunity of the United States and thus dispensing with the need to sue the officer, Congress sought to rationalize this area of the law. ${ }^{296} \mathrm{Be}-$ cause the regime the APA seeks to rationalize made no distinction between official action violative of treaties and official action violative of statutes or the Constitution, ${ }^{297}$ no such distinction should be read into the APA. To hold the APA inapplicable to agency action that is unlawful because it violates a treaty would not be to make such treaties unenforceable; rather, it would be to resurrect the prior regime, with all of its complications and inadequacies, with respect to treaty cases. There is no justification for doing so.

Moreover, a distinction between federal agency action that violates a statute and federal agency action that violates a treaty would be both unworkable and illusory. Virtually all federal agency action that violates a treaty will also violate a statute. It is well established that, unless Congress clearly says otherwise, federal statutes are to be construed consistently with our treaty obligations. ${ }^{298}$ Thus, unless Congress has clearly said otherwise, federal statutes delegating authority to federal officers do not delegate authority to violate treaties. Accordingly, federal agency action that allegedly violates a treaty obligation of the United States also exceeds the scope of the statute delegating authority to the agency. Judicial review of the agency action that allegedly exceeds the scope of the agency's delegated authority is of course precisely what the APA has always been thought to address.

In short, in suits against state and federal officials, a right of action is afforded by section 1983 and the APA, respectively, to any person holding a primary right under a treaty unless either a treaty or a statute makes other procedures exclusive or affirmatively precludes review. ${ }^{299}$

context as in others, "[i]f there be an admitted wrong, the courts will look far to supply an adequate remedy." DeLima v. Bidwell, 182 U.S. 1, 176-77 (1901).

295. Then Assistant Attorney General Scalia used this phrase to describe the law concerning the applicability of sovereign immunity to the officer cases described above. See supra note 280-81 and accompanying text. To rationalize this area, Congress amended the APA in 1976 to waive the United States' sovereign immunity in APA suits, thus dispensing with the need to sue the officer. See H.R. Rep. No. 94-1656, 94th Cong., 2d Sess. 6, reprinted in 1976 U.S.C.C.A.N. $6121,6126$.

296. See id. at 6140 .

297. See supra note 266.

298. See Restatement (Third) of the Foreign Relations Law of the United States $\S 114$ (1986).

299. Review is unavailable under section 1983, the APA, or any of the other sources of nonstatutory review if a law (or treaty) sets forth exclusive alternative enforcement mechanisms or (in the absence of constitutional problems) otherwise precludes review. lt will thus be necessary in such suits to consult the enforcement mechanisms, if any, of the treaty. But, contrary to what some courts appear to believe, the absence of such mechanisms does not mean that there is no right of action. The issue is whether the 
Both statutes, in their respective spheres, "close the gap between primary right and remedial right, making the existence of the former determinative of the existence of the latter."300 It should thus be unnecessary in the categories of cases of most concern here to locate a right of action in the treaty itself.

In light of these two statutes, whether the treaty itself confers a right of action will generally be an issue only with respect to treaties

treaty's mechanisms are exclusive. Indeed, the absence of enforcement mechanisms in the treaty militates in favor of the individual seeking to enforce the treaty's obligations through the rights of action discussed in the text. There is a strong presumption, moreover, that these rights of action have not been foreclosed. See Wright v. City of Roanoke Redev. Hous. Auth., 479 U.S. 4I8, 423-24 (1987) (cause of action available unless "state actor demonstrates by express provision or other specific evidence from the statute itself that Congress intended to foreclose such private enforcement. "We do not lightly conclude that Congress intended to preclude reliance on § I983 as a remedy' for the deprivation of a federally secured right," quoting Smith v. Robinson, 468 U.S. 992, 1012 (1984)); Abbott Laboratories v. Gardner, 387 U.S. 136, 141 (1967) ("[O]nly upon a showing of 'clear and convincing evidence' of a contrary legislative intent should the courts restrict access to judicial review [of federal agency action]," quoting Rusk v. Cort, 369 U.S. 367, 379-80 (1962)).

A right of action may also be foreclosed by a statute, as opposed to the treaty itself. See Lem Moon Sing v. United States, 158 U.S. 538, 546-50 (1895) (statute declaring decision of immigration and customs officer "final" unless reversed by Secretary of the Treasury precludes review by habeas corpus), limited by Gegiow v. Uhl, 239 U.S. 3, 9 (19I5) ("[C]onclusiveness of the decisions of immigration officers . . . is conclusiveness upon matters of fact.").

300. Monaghan, supra note 26, at 251. Professor Monaghan was here referring to section 1983, but later observes that the APA standing decisions and those under section I983 are converging. See id. at 255. Of course, with respect to federal officers, the APA leaves open a substantial gap by not providing for retrospective relief, a gap that the FTCA only partially closes.

The recent decision in Suter v. Artist M., 112 S. Ct. 1360 (1992) may signal a retrenchment from the Dennis $v$. Higgins analytical framework, see id. at 1371 (Blackmun, J., dissenting), in that, in the section 1983 context, the Court required evidence that Congress "unambiguously confer[red] upon the ... beneficiaries of the [federal statute] a right to enforce [the statute]," id. at 1367. Read broadly, the decision would render section I983 superfluous, since it would afford a right of action only if one may be implied under the statute under Cort v. Ash, 422 U.S. 66 (I975). The decision need not be read so broadly, however. The Court's approach was influenced by the fact that the statute involved was enacted under the Spending Clause, which requires a particularly clear intent to subject the state to liabilities. See I12 S. Ct. at 1366. Additionally, the Court appeared to hold that an enforceable right was lacking because the federal law was "not specific" and did not provide "statutory gnidance" and thus left the states with "a great deal of discretion," id. at I368-69; the decision is thus not a "right of action" holding under the framework proposed herein, but rather a holding that the law did not impose on the state the obligation the litigant was seeking to enforce. See supra text accompanying notes 148-154; cf. $112 \mathrm{~S}$. Ct. at 1370 (statute imposes "only a rather generalized duty on the State").

To the extent that the Court reopens the gap between primary rights and secondary rights Dennis v. Higgins had closed, or if section 1983 or the APA were for some reason read not to apply to treaty-based rights, the analysis proposed here for determining whether a right of action is implicit in the treaty itself should be employed to determine whether a treaty itself confers a right of action against state and federal officials. 
that confer primary rights on individuals vis-à-vis other individuals. In such cases, when the treaty expressly obligates the United States to afford particular remedies to individuals, those remedies are available to those individuals without legislation by virtue of the Supremacy Clause. ${ }^{301}$ If the treaty is silent as to remedies, and no common-law action is available, it is necessary to consider whether a right of action is nevertheless implicit in the treaty. Until relatively recently, if a statute conferred a primary right, as defined above, the courts generally implied a right of action for damages or other appropriate relief, 302 in the absence of a clear legislative intent to make other enforcement mechanisms exclusive. ${ }^{303}$ This approach was applied to constitutional claims beginning with Bivens v. Six Unknown Named Agents. ${ }^{304}$ In Cort v. Ash, 305 however, the Court began to take a self-consciously more restrictive approach to implying rights of action for damages under statutes. ${ }^{306}$ The individual's status as an intended beneficiary of a statute became just one of four factors, and the "focus" of the analysis became whether Congress affirmatively intended to create a right of action. ${ }^{307}$ In several cases, the Court has declined to infer a right of action under a statute even though it found the plaintiff to be an intended beneficiary. ${ }^{308}$ With respect to constitutional claims, however, the Court has adhered to its comparatively hospitable, pre-Cort approach to implying rights of action.

Although the Court has not, since Cort, addressed the proper test for implying rights of action from treaties, several factors militate in favor of employing a third approach, more closely resembling the ap-

301. See, e.g., Hughes v. Edwards, 22 U.S. (9 Wheat.) 489, 496-97 (1824); Harden v. Fisher, 14 U.S. (1 Wheat.) 300, 301 (1816); Fairfax's Devisee v. Hunter's Lessee, 11 U.S. (7 Cranch) 603, 627 (1812).

302. See, e.g., Merrill Lynch, Pierce, Fenner \& Smith, Inc. v. Curran, 456 U.S. 353, 374 (1982) ("If a statute was enacted for the benefit of a special class, the judiciary normally recognized a remedy for members of that class."); Texas \& Pac. Ry. v. Rigsby, 241 U.S. 33, 39 (1916) ("[W] here [disregard of statute] results in damage to one of the class for whose especial benefit the statute was enacted, the right to recover . . . is implied.").

303. See Securities Investor Protection Corp. v. Barbour, 421 U.S. 412, 420-21 (1975); National R.R. Passenger Corp. v. National Ass'n of R.R. Passengers, 414 U.S. 453, 464-65 (1974).

304. 403 U.S. $388,392,396$ (1971).

305. 422 U.S. 66 (1975).

306. See Merrell Dow Pharmaceuticals, Inc. v. Thompson, 478 U.S. 804,811 (1986) ("The development of our framework for determining whether a private cause of action exists has proceeded only in the last 11 years, and its inception represented a significant change in our approach to congressional silence on the provision of federal remedies."); Curran, 456 U.S. at 377 ("In 1975 the Court unanimously decided to modify its approach ....").

307. See Thompson v. Thompson, 484 U.S. 174, 179 (1988).

308. See Massachusetts Mut. Life Ins. Co. v. Russell, 473 U.S. 134, 145 (1985); Daily Income Fund, Inc. v. Fox, 464 U.S. 523, 541 (1984); Transamerica Mortgage Advisers, lnc. v. Lewis, 444 U.S. 11, 24 (1979). 
proach the Court applies today with respect to constitutional claims. ${ }^{309}$ First, the Court has justified its retrenchment in the statutory context on the ground that

statutory rights and obligations are often embedded in complex regulatory schemes, so that if they are not enforced through private causes of action, they may nevertheless be enforced through alternative mechanisms .... The Constitution, on the other hand, does not "partake of the prolixity of a legal code." 310

In this regard, treaties resemble the Constitution far more closely than statutes. ${ }^{311}$ Second, the Court's continuing hospitable approach to implying rights of action under the Constitution is based in part on the intent of the Framers to make the courts the primary enforcers of constitutional rights. ${ }^{312}$ We saw above that the Framers had a similar intent with respect to treaties. ${ }^{313}$ Third, the clear statement rule that Cort and its progeny impose on Congress comes at relatively little cost, as Congress can easily correct a decision denying a right of action under a statute. $^{314}$ It is, however, far less appropriate to impose a clear statement obligation on our treaty partners even with respect to future treaties; it is entirely illegitimate to subject pre-Cort treaties to such a standard. Finally, and most importantly, the consequences of denying beneficiaries of treaty obligations the power to enforce them in court

309. The Ninth Circuit expressly held that the Cort analysis was not applicable in determining whether a right of action is implicit in Article 17 of the Warsaw Convention. See In re Mexico City Aircrash of October 31, 1979, 708 F.2d 400, 409 (9th Cir. 1983); see also Benjamins v. British Eur. Airways, 572 F.2d 913 (2d Cir. 1978) (neither the majority opinion implying a right of action, nor dissenting opinion, employs the Cort test).

310. Davis v. Passman, 442 U.S. 228, 241 (1979) (quoting McCulloch v. Maryland, 17 U.S. (4 Wheat.) 316, 407 (1819)).

311. See Shabtai Rosenne, Developments in the Law of Treaties, 1945-1986, at 59 (1989) (treaties "are rarely if ever drafted with that degree of precision and carefully chosen language that one would expect to find in a well-drafted private-law contract or in good parliamentary drafting"). If treaties do include their own complex enforcement scheme, it might be appropriate to deny a private right of action, but this is more appropriately accomplished through rules applied in the constitutional context and in the context of section 1983. See supra note 299. In reality, the cases in which the Court has denied a private right of action to intended beneficiaries have been cases in which there was strong evidence of an intent to make alternative enforcement mechanisms exclusive. See Russell, 473 U.S. at 147; Fox, 464 U.S. at 539; Transamerica, 444 U.S. at 20. In this respect, the difference between the test proposed here and the Cort test as applied to statutes may thus not be significant.

312. See Davis, 442 U.S. at 241-42.

313. See supra part 11.B.

314. See Karahalios v. National Fed'n of Fed. Employees, 489 U.S. 527, 536 (1989) ("Congress undoubtedly was aware from our prior cases such as [Cort] that the Court had departed from its prior standard for resolving a claim urging that an implied statutory cause of action should be recognized ... ."); Touche Ross \& Co. v. Redington, 442 U.S. 560, 579 (1979) ("[1]f Congress intends those customers to have such a federal right of action, it is well aware of how it may effectuate that intent."). 
through a private action are, or should be, of greater concern to the nation, as the failure of the courts to remedy a violation of a foreign national's primary rights under a treaty would render the United States responsible on the international plane to the state of the individual's nationality. As explained in greater detail below, every treaty obligating a state to treat individuals in given ways includes, as a matter of international law, an implicit obligation to provide redress if the individual is injured by a state's failure to afford him the required treatment. In treaty cases, therefore, an important factor in determining whether a private right of action should be "implied" under a treaty that does not expressly confer one is whether failure of the courts to afford the remedy would produce (or exacerbate) the international responsibility of the United States to the state of the individual's nationality. If it would, a private right of action to obtain that remedy under domestic law should be considered to be implicit in the treaty. ${ }^{315}$

b. Remedies. - If the individual's right of action is conferred by a general statute, such as section 1983 or the APA, or if the individual is invoking the treaty as a defense, it will be necessary to determine the appropriate remedy in a given case. If the treaty itself specifies that the individual should be afforded a particular remedy, the individual is entitled to the remedy by virtue of the Supremacy Clause. ${ }^{316}$ If the treaty is silent as to remedies, however, it is important to consider a second respect in which treaties are interstitial. Unlike federal statutes, treaties are interstitial in two legal orders at the same time. In the international legal order, treaties are concluded by states against a background of customary international law. Norms of customary international law specify the circumstances in which the failure of one party to fulfill its treaty obligations will permit the other to rescind the treaty, retaliate, or take other steps. At a more general level, norms of customary international law address the secondary rights of states that arise upon a violation by other states of primary rules of international law, including those having their source in a treaty. Like individuals who enter into contracts governed by municipal law, the parties to a treaty may address some remedial issues in the treaty itself. They may, however, leave remedial matters to the default rules of customary international law that-like municipal contract law-govern those matters that the parties have left unaddressed.

If a treaty obligates the parties to treat individuals in a given way but does not specify a remedy for failure to comply with the obligation, the default rules of customary international law dictate the secondary

315. The rule proposed herein might be subject to one exception: it should arguably be unavailable when the United States agrees on a different reparation directly with the state of the individual's nationality. In such situations, the agreement might be deemed a waiver by the state of the individual's nationality of the United States' obligations under the treaty. See supra note 235 .

316. See supra note 301 . 
rights of the state of the individual's nationality and the corresponding secondary duties of the offending state. In many instances, the secondary duty will be a duty to treat the individual in a given way. For example, Professor Schachter, addressing the secondary rights (and correlative secondary duties) of states for violations of primary rules of international law, has written as follows:

When a State is internationally responsible for a wrongful act, it is under an obligation to discontinue the act and to prevent the continuing effects of the act. It is also normally under a duty to restore the situation as it existed before the breach. ...

The question of whether compensation is a permissible substitute for restoration (or restitution) has given rise to much controversy. Clearly, [however,] an offending State is under a duty to return an object held unlawfully or to return territory illicitly held as long as that is materially possible. ${ }^{317}$

Thus, if one state unlawfully takes an individual (an "object" under international law) from the territory of his state of nationality, and is holding him unlawfully, the offended state is entitled under customary international law to have its national returned. Because the treaty was entered into against a background of customary interuational law, the rule of customary international law requiring that objects unlawfully held be returned should be read into the treaty prohibiting the taking as if it had been incorporated therein expressly. ${ }^{318}$

As a matter of international law, the remedy is considered to be

317. Oscar Schachter, General Course in Public International Law, 178 Recueil des Cours 190-91 (1984) (emphasis added); accord Restatement (Third) of Foreign Relations Law of the United States $\S 901 \mathrm{cmt}$. d (1987).

318. This would certainly be the case under international law rules of treaty interpretation. The Vienna Convention, which is considered declaratory of customary international law of treaty interpretation, provides that in the interpretation of a treaty provision, "there shall be taken into account, together with the context, . . . any relevant rules of international law applicable in the relations between the parties." Vienna Convention on the Law of Treaties, art. 31, supra note 154 , at 340 .

Of course, for purposes of international law, there is no need to determine whether the remedy has its basis in the treaty or customary international law. Both are equally binding on the parties. For purposes of domestic law, however, there may be a distinction between the two for determining whether the courts may require compliance by the executive. The Supremacy Clause, in conjunction with the Take Care Clause, provide a stronger textual basis for concluding that the courts may order the executive to comply with treaty-based obligations. See, e.g., The Paquete Habana, 175 U.S. 677, 700 (1900) (in the absence of a treaty or other "controlling executive or legislative act or judicial decision," courts must resort to the customs or usages of civilized nations). 1 do not propose to consider here whether the courts must afford individuals remedies required by customary international law because customary international law is "part of our law." Rather, I advocate the more limited conclusion that (a) customary international law of remedies for violation of primary rnles of international law should, for purposes of our domestic law, be considered to be incorporated into treaties that impose primary obligations on states, and (b) individuals should be deemed to be entitled to the remedy by virtue of the Supremacy Clause to the extent that affording the 
that of the state of the individual's nationality, not of the individual himself. But the statement that only the state has a remedy under international law means that only the state may set in motion the machinery of international law for sanctioning the violation. That conclusion should have little bearing on whether the individual should be entitled to obtain a sanction for the violation in domestic courts. The reasons that led me to conclude that the Supremacy Clause transforms the primary rights of states into the primary rights of individuals who are intended beneficiaries of the correlative obligation equally support the conclusion that the clause similarly transforms the secondary rights of states into the secondary rights of those same individuals.

When a state's primary obligation under a treaty is an obligation to behave in a given way towards individuals, an additional default rule of customary international law imposes an obligation on the parties to the treaty to afford the individual a remedy domestically. I refer here to the international law doctrine of exhaustion of local remedies, which makes the international law responsibility of the offending state to the state of the individual's nationality contingent on the individual's having sought and been denied redress in the offending state's local courts. ${ }^{319}$ This doctrine of international law may be said to entitle the individual to a remedy in the offending state's local courts in the very same way that the treaty gives the individual a primary right: in both cases the sanction is the international responsibility of the offending state to the state of the individual's nationality.

As we saw above, to an extreme sanctionist this sort of entitlement does not give the individual a legal right under international law because the individual in fact has such a remedy only if the domestic law of the offending state gives him the remedy. ${ }^{320}$ Such a sanctionist would

remedy would prevent, cure, or reduce the United States' responsibility to the state of the individual's nationality under international law.

319. See generally Amerasinghe, supra note 22, at 45-51 (exhaustion of local remedies required); Ian Brownlie, Principles of Public International Law 494-505 (4th ed. 1990) (rights and remedies of aliens under local and international law); Castor H.P. Law, The Local Remedies Rule in International Law 15-16 (1961)(defining exhaustion and justifying its use); Max Sorenson, Manual of Public International Law 582-91 (1968) (defining rnle and applications); Algot Bagge, Intervention on the Ground of Damage Caused to Nationals, with Particular Reference to Exhaustion of Local Remedies and the Rights of Shareholders, 1958 Brit. Y.B. Int'l L. 162, 165-69 (exhaustion requires balancing private burdens and state sovereignty); David R. Mummery, The Content of the Duty to Exhaust Local Judicial Remedies, 58 Am. J. Int'l L. 389 (1964) (exhaustion rooted in states' jurisdiction over persons within their borders). The remedy afforded must "rectify the situation," Mummery, supra, at 401 , and be "acceptable on the international plane," Sorenson, supra, at 584. Although international law does not require that the local remedy be afforded by a court, the usual method of exhausting local remedies is to bring suit in the local courts. In any event, for the reasons cited infra note 322, in the United States the courts are the appropriate agencies for affording the remedy required by international law. 
consider any "right" of the individual in such a situation to be a right under domestic law. ${ }^{321}$ At bottom, therefore, the conclusion that the individual does not have a right under international law is based on the understanding that the availability of the remedy depends on domestic incorporation of the international law rule requiring remedy by the offending state.

The United States, however, has incorporated treaties into domestic law through the Supremacy Clause. The purpose and effect of this incorporation was precisely to alter, for purposes of our domestic law, the international law rule pursuant to which only states were thought to have rights and remedies under treaties. The Framers' reasons for making treaties the law of the land and requiring the courts to give them effect require the conclusion that, in those circumstances in which affording a remedy to the individual would avoid or cure (entirely or partially) a treaty violation against the state of the individual's nationality, the individual is entitled to the remedy by virtue of the Supremacy Clause.

As discussed in Part 1I, the Framers were concerned about treaty violations in part because such violations could offend other states and perhaps lead to calamity and war. The Framers empowered foreign nationals to utilize our courts to enforce the nation's treaty commitments in part to cure any such violations before they gave rise to international friction. As Hamilton wrote in defending Article III's conferral of jurisdiction over cases involving aliens:

The Union will undoubtedly be answerable to foreign powers for the conduct of its members. And the responsibility for an injury ought ever to be accompanied with the faculty of preventing it. As the denial or perversion of justice by the sentences of courts, as well as in any other manner, is with reason classed among the just causes of war, it will follow that the federal judiciary ought to have cognizance of all causes in which the citizens of other countries are concerned. ${ }^{322}$

It was thus contemplated that the federal courts would guard against offenses to foreign states by ensuring that foreign nationals were not denied justice in our courts. Hamilton's arguments of course extend beyond the application of treaties: the international law duty not to deny justice to an alien applies whether or not the alien's underlying claim is based on international law. But, although the concepts are dis-

321. See Austin, supra note 26, at 594 ("Each state may . . . enforc[e] [international] law by its own tribunals . . . . This, however, is not International, but National or Civil Law; i.e. in regard to the sanction.").

322. The Federalist No. 80, at 476 (Alexander Hamilton) (Clinton Rossiter ed., I96I); accord 2 The Documentary History of the Ratification of the Constitution 520 (Merrill Jensen ed., 1976) (statement of James Wilson at the Pennsylvania Convention) ("It was thought proper to give the citizens of foreign states full opportunity of obtaining justice in the general courts, and this they have by its appellate jurisdiction. ... [ [I]t is necessary to preserve peace with foreign nations."). 
tinct, the rules concerning denial of justice and those concerning exhaustion of local remedies are related in that they both require the local courts to adhere to an international standard in affording remedies to aliens. ${ }^{323}$ Moreover, as Hamilton acknowledged, the reasons for extending federal jurisdiction to all cases involving aliens apply even more strongly to "cases arising upon treaties and the law of nations." 324 The Supremacy Clause and its jurisdictional corollary in Article III (in their application to treaties), were designed to avert violations of international law by the United States by empowering intended beneficiaries of treaty obligations of the United States either to enforce those obligations or to obtain such remedies as would cure the violation as a matter of international law. This is exactly the purpose of the international-law doctrine of exhaustion of local remedies. ${ }^{325}$ The Supremacy Clause's declaration that treaties are the "Law of the Land" should accordingly be interpreted by reference to the international law rules obligating the United States to afford individuals adequate domestic remedies for violations of treaties. The clause should be read to require the courts to afford individuals, at a minimum, such remedies as would avoid or cure a violation of international law by the United States against the state of the individuals' nationality.

\section{CoNCLUSION}

The oft-repeated proposition that individuals do not have rights under treaties under interuational law means only that individuals do not have standing to enforce treaties in the international arena. That disability has no bearing on the ability of individuals to enforce treaties in our domestic courts. The Framers recognized that treaties, as international instruments, did not operate on individuals. By declaring treaties to be the "supreme Law of the Land," they intended to alter this quality of treaties for purposes of our domestic law. The Supremacy Clause made treaties operative on individuals and enforceable in the ordinary courts at the behest of individuals.

I have proposed in this Article a framework for determining which treaties may be enforced in the courts and by whom. The courts must first consider whether the treaty imposes judicially enforceable obligations. A treaty may not impose obligations at all, or the obligations it

323. See Alwyn V. Freeman, International Responsibility of States for Denial of Justice 403-55 (1938); Mummery, supra note 3I9, at 4I1-14.

324. The Federalist No. 80 , supra note 322, at 476 ; see also Mummery, supra note 319 , at 414 (although denial of justice and exhaustion of local remedies are distinct, denial of justice "will at times provide a fortiori examples of ineffective local judicial remedies").

325. See Freeman, supra note 323 , at 408 ("By appropriately redressing violations of international law with respect to the person or property of foreigners, the State asserts a check upon its answerability to other States, discharges the responsibility that has already been engaged, and thus parries, as it were, by anticipation, a reaction from abroad."). 
imposes may be addressed to the legislature, or they may not be enforceable judicially for residual separation-of-powers reasons.

If the treaty does impose judicially enforceable obligations, the court must determine whether the individual seeking to enforce it has standing to invoke it. I propose employing for this purpose the standing rules that are used to determine whether an individual has standing to enforce statutory or constitutional duties of the state. If the treaty is being invoked by a plaintiff, the court must also determine that the plaintiff has a right of action. The right of action, however, need not have its source in the treaty. Ordinarily, a right of action for enforcement of a treaty against state and federal officials will be provided by section 1983 and the APA, respectively. Finally, the court must determine what the appropriate remedy for the treaty violation is. For this purpose, I propose that the court consult the rules of international law specifying the appropriate remedy for international law violations and "entitling" the individual to obtain the remedy domestically. Because the Supremacy Clause was adopted in part to prevent or cure violations of international law by the United States before they gave rise to international friction, the clause should be read to require the courts to award to individuals at least such remedies as would prevent or cure (partially or wholly) international responsibility of the United States to the state of the individual's nationality.

\section{ADDENDUM}

As this issue went to press, the Supreme Court handed down its decision in United States $v$. Alvarez Machain:326 Disagreeing with the Ninth Circuit's holding in Verdugo, on which the Court of Appeals in Alvarez had relied, ${ }^{327}$ the Supreme Court held that the United StatesMexico Extradition Treaty did not prohibit unilateral abductions by U.S. officials of persons in Mexican territory. The Court accordingly did not reach the issue that is the focus of this Article: under what circumstances may individuals enforce in our courts obligations imposed by treaty on the United States. ${ }^{328}$ Justice Stevens, joined by Justices Blackmun and O'Connor, dissented. They concluded that the treaty did prohibit unilateral abductions and that the defendant had

326. 60 U.S.L.W. 4523 (U.S. June 16, 1992).

327. See supra notes 11 and 13 and accompanying text.

328. The majority noted, nonetheless, that " $[\mathrm{t}] \mathrm{he}$ Extradition Treaty has the force of law, and if, as respondent asserts, it is self-executing, it would appear that a court must enforce it on behalf of an individual regardless of the offensiveness of the practice of one nation to the other nation." 60 U.S.L.W. at 4527 . The majority thus recognized that the question of a treaty's "self-executing" nature is distinct from the question of its status as domestic law, apparently disagreeing with the lower courts that have suggested that only treaties that are self-executing are the law of the land. See supra notes 143-145 and accompanying text. 1t also apparently concluded, in agreement with this Article, that a protest by the offended state should not he a prerequisite of an individual's standing to enforce a treaty. See supra note 235 . 
standing to assert the rights of Mexico in our courts if Mexico protested. ${ }^{329}$ The court summarily vacated the Ninth Circuit's judgement in Verdugo, and remanded the case for further proceedings consistent with Alvarez. ${ }^{330}$

329. 60 U.S.L.W. at 4531 n.26.

330. 60 U.S.L.W. 3857 (U.S. June 23, 1992). 